http://dx.doi.org/10.18778/8088-836-4.01

\title{
Analizy weryfikacyjne - przeszłe i obecne doświadczenia badawcze
}


畒 
Katarzyna Grzeszkiewicz-Radulska Aneta Krzewińska

\section{Analizy weryfikacyjne - przeszłe i obecne doświadczenia badawcze}

TOM XIII 
Katarzyna Grzeszkiewicz-Radulska, Aneta Krzewińska - Uniwersytet Łódzki Wydział Ekonomiczno-Socjologiczny, Katedra Metod i Technik Badań Społecznych 90-214 Łódź, ul. Rewolucji 1905 r. nr 41/43

\author{
REDAKTOR NAUKOWY SERII \\ ANALIZY I PRÓBY TECHNIK BADAWCZYCH W SOCJOLOGII \\ Anna Kubiak
}

\author{
RECENZENT \\ Krystyna Janicka \\ REDAKTOR INICJUJĄCY \\ Iwona Gos \\ REDAKTOR WYDAWNICTWA UŁ \\ Joanna Balcerak \\ SKŁAD I ŁAMANIE \\ AGENT PR \\ PROJEKT OKŁADKI \\ Katarzyna Turkowska
}

(c) Copyright by Authors, Łódź 2017

(c) Copyright for this edition by Uniwersytet Łódzki, Łódź 2017

Wydane przez Wydawnictwo Uniwersytetu Łódzkiego
Wydanie I. W.08157.17.0.K

Ark. wyd. 8,5; ark. druk. 7,875

e-ISBN 978-83-8088-836-4

Wydawnictwo Uniwersytetu Łódzkiego

90-131 Łódź, ul. Lindleya 8

www.wydawnictwo.uni.lodz.pl

e-mail: ksiegarnia@uni.lodz.pl

tel. (42) 6655863 
Naszym Mistrzom, Nauczycielom Krystynie Lutyńskiej, Janowi Lutyńskiemu, Zygmuntowi Gostkowskiemu 



\section{Spis treści}

Rozdział 1

\section{Analizy weryfikacyjne w tódzkiej szkole metodologicznej}

1.1. Łódzka szkoła metodologiczna - krótka historia i ramy instytucjonalne 11

1.2. Przedmiot zainteresowań socjologów z łódzkiej szkoły metodologicznej 16

1.3. Analizy weryfikacyjne - koncepcja teoretyczna Jana Lutyńskiego 22

1.3.1. Założenia metodologiczne prowadzenia analiz weryfikacyjnych 24

1.3.2. Weryfikacja zewnętrzna - procedury, metody, ograniczenia 25

1.3.3. Weryfikacja wewnętrzna - procedury, metody, ograniczenia 28

1.4. Analizy weryfikacyjne z dzisiejszej perspektywy - ocena współpracowników i uczniów Jana Lutyńskiego

\section{Rozdział 2}

Nowe możliwości weryfikacji wewnętrznej. Winiety zakotwiczające jako technika obiektywizacji samoocen respondentów w badaniach sondażowych

2.1. Błąd, jakim mogą być obciążone samooceny $\quad 40$

2.2. Konstrukcja narzędzia 43

2.3. Założenia techniki $\quad 45$

2.4. Nieparametryczna metoda opracowania materiałów - modele relatywnych rang 48

2.5. Parametryczna metoda opracowania materiałów - model CHOPIT 59

\section{Rozdział 3}

Empiryczne zastosowania techniki winiet zakotwiczających $\quad 65$

3.1. Cel badań i baza materiałowa 66

3.2. Wyniki badania sytuacji materialnej $\quad 67$

3.2.1. Ustalenie dominującego wzoru uporządkowania winiet 69

$\begin{array}{ll}\text { 3.2.2. Wyniki metody nieparametrycznej } & 72\end{array}$

3.2.3. Wyniki metody parametrycznej 83 
3.3. Wyniki badania potrzeby doskonalenia własnych kwalifikacji zawodowych 86

3.3.1. Ustalenie dominującego wzoru uporządkowania winiet $\quad 89$

3.3.2. Wyniki metody nieparametrycznej 92

3.3.3. Wyniki metody parametrycznej 103

$\begin{array}{ll}\text { 3.4. Podsumowanie } & 106\end{array}$

Zakończenie $\quad 111$

Bibliografia $\quad 115$

$\begin{array}{ll}\text { Załączniki } & 121\end{array}$

Verification analysis in social surveys. Past and present research experiences (Summary) 125 


\section{Od Redakcji}

Pierwszy tom Analiz i prób technik badawczych w socjologii ukazał się w roku 1966. Było to pionierskie i wówczas jedyne systematyczne wydawnictwo w Polsce, prezentujące przedsięwzięcia badawcze i refleksję dotyczącą stosowania różnorodnych technik badawczych - ich możliwości, rozwiązań proceduralnych oraz rzetelności uzyskiwanych informacji. Do roku 2009 ukazało się 12 tomów. Twórcami serii wydawniczej, na którą składają się zarówno prace zbiorowe, jak i monografie, byli nasi nauczyciele i mistrzowie, profesorowie Zygmunt Gostkowski i Jan Lutyński. Zdecydowaliśmy się na kontynuację tego przedsięwzięcia, gdyż wiele poruszanych wcześniej zagadnień nie znalazło satysfakcjonujących rozwiązań - pojawiły się nowe wyzwania, wymagające systematycznych badań i analiz metodologicznych. Seria Analizy i próby... nadal może stanowić ważne forum wymiany doświadczeń i przemyśleń, nie tylko dla metodologów. Jej kolejne tomy będą prezentowane w wersji internetowej, ogólnie dostępnej m.in. w Repozytorium Uniwersytetu Łódzkiego' ${ }^{1}$.

Tom XIII autorstwa Katarzyny Grzeszkiewicz-Radulskiej i Anety Krzewińskiej, publikowany obecnie (po uzyskaniu praw do wydawania serii), inauguruje internetową wersję - by nie powiedzieć „erę" - serii wydawniczej. Autorki przedstawiają własną interpretację dotychczasowych dokonań, skoncentrowanych wokół analiz weryfikacyjnych - ich różnych wariantów, procedur, możliwości. Omawiają współczesne zastosowania procedur weryfikacyjnych na przykładzie techniki winiet zakotwiczających ${ }^{2}$.

W przygotowaniu jest tom XIV Analiz i prób technik badawczych w socjologii, pomyślany jako „biografia” całej serii wydawniczej. Do współtworzenia następnych tomów zapraszamy osoby zainteresowane prezentacją własnych przemyśleń i przedsięwzięć badawczych z zakresu metodologii i metodyki badań socjologicznych.

Anna Kubiak

1 Pod adresem internetowym: http://dspace.uni.lodz.pl:8080/xmlui/handle/11089/2749 Czytelnik znajdzie zawartość wszystkich dotychczasowych 12 tomów.

2 Ta część książki opiera się na obszernych fragmentach pracy dyplomowej K. Grzeszkiewicz-Radulskiej pt. Winiety zakotwiczajq̨ce jako technika obiektywizacji samoocen respondentów, napisanej w 2016 r. pod kierunkiem dra Piotra Wójcika na Wydziale Nauk Ekonomicznych Uniwersytetu Warszawskiego w ramach studiów podyplomowych Metody statystyczne $w$ biznesie. 



\section{Analizy weryfikacyjne w tódzkiej szkole metodologicznej}

\section{1. Łódzka szkoła metodologiczna - krótka historia i ramy instytucjonalne}

Przywołany termin „łódzka szkoła metodologiczna”, którego zwyczajowo używa się na określenie grupy łódzkich metodologów skupionych wokół Jana Lutyńskiego i Zygmunta Gostkowskiego, jest stosowany od lat 80. XX w., chociaż pierwsze pisemne wzmianki dotyczące tej szkoły (lecz nie samej grupy badaczy) znajdują się w tekście Edmunda Mokrzyckiego. To on w 1990 r. w swoim opracowaniu Socjologia w filozoficznym kontekście zastosował określenie „łódzka szkoła metodologiczna” podkreślając, że pracujący w niej badacze charakteryzują się specyficznym sposobem uprawiania socjologicznej metodologii ${ }^{1}$, co ich odróżnia od innych naukowców. Pisał wtedy, że w Łodzi „[...] rozwinęła się łódzka szkoła metodologiczna, zjawisko unikalne w skali światowej. Jak wiadomo, szkoła ta uprawia tzw. empiryczną metodologię badań socjologicznych, to jest w praktyce badań opartych na wywiadzie kwestionariuszowym i pokrewnych metodach zbierania informacji. Metody te poddaje się tu testom głównie w warunkach quasi-eksperymentalnych, formułując na tej (empirycznej) podstawie wnioski ogólne. Wnioski te sumują się obecnie w pewnego rodzaju teorię badań opartych w warunkach polskich na wypowiedzi i ujawniają ogromną złożoność rzeczywistych procesów badawczych w porównaniu z modelowymi założeniami standardowej metodologii” (Mokrzycki 1990: 20-21).

1 Podobne kryterium - sposób uprawiania danej dziedziny naukowej - było wyróżnikiem filozoficznej szkoły lwowsko-warszawskiej, którą scharakteryzował Jan Woleński w artykule Kilka uwag (naukoznawczych) o Szkole Lwowsko-Warszawskiej pisząc: „Pomijając zbyt specjalistyczne kwestie, wspólnym, by tak rzec, dobrem intelektualnym Szkoły Lwowsko-Warszawskiej były przeświadczenia metafilozoficzne dotyczące tego, jak filozofia winna być uprawiana. Obok wspomnianej już precyzji i ścisłości postulowano oddzielenie filozofii od światopoglądu, zarówno politycznego, jak i religijnego" (Woleński 2014: 38). 
Jakie cechy świadczą o tym, że określenie „łódzka szkoła metodologiczna” może być stosowane w odniesieniu do grupy badaczy zajmujących się metodologią? Jeśli w próbie scharakteryzowania tej szkoły posłużymy się wyróżnionymi i opisanymi przez Zbysława Muszyńskiego cechami przysługującymi szkole naukowej², to będziemy odwoływali się do postaci mistrza, genealogii, czasu, miejsca, samoświadomości, wspólnoty poglądów (rdzenia ideowego i metodologicznego) oraz traktowanych łącznie pism, stylów i światopoglądów (Muszyński 2014). Zdaniem Muszyńskiego, nauka jest uprawiana we wspólnotach, których nieformalną postacią jest szkoła naukowa. Nieformalność oznacza tu brak dekretów założycielskich, oficjalnych powołań lub nadań i to, że istnienie szkoły najczęściej zauważane jest (nazywane i opisywane) przez zewnętrznych obserwatorów. Nie inaczej było w przypadku łódzkiej szkoły metodologicznej.

Początki tej szkoły powinny być wiązane z pierwszą połową lat 60., kiedy Zygmunt Gostkowski opublikował tekst $Z$ zagadnień socjologii wywiadu, będący zwiastunem nakreślenia obszaru zainteresowań oraz sposobu prowadzenia badań. W artykule zamieszczonym w „Studiach Socjologicznych” Gostkowski prezentował założenia koncepcji dotyczącej społecznego wymiaru/kontekstu relacji łączącej badacza z badanym. Gdy pięć lat później ukazał się pierwszy tom Analiz i prób technik badawczych w socjologii ${ }^{3}$ (1966), ukonstytuowały się i podjęły współpracę naukową dwie grupy socjologów: skupiona wokół Jana Lutyńskiego grupa pracowników Instytutu Socjologii Uniwersytetu Łódzkiego oraz kierowana przez Zygmunta Gostkowskiego grupa zatrudnionych w Zakładzie Metodologii Badań Socjologicznych Instytutu Filozofii i Socjologii Polskiej Akademii Nauk z siedzibą w Łodzi. Oprócz skupionych wokół J. Lutyńskiego i Z. Gostkowskiego socjolo-

2 Podejście Z. Muszyńskiego, związane z charakterystyką szkół naukowych, wpisuje się raczej w strukturalne niż w genetyczne rozumienie tego terminu. To rozróżnienie przywołał Jerzy Szacki w swoim artykule O szkołach naukowych (Zarys problematyki) pisząc, że w podejściu genetycznym istotna jest przede wszystkim geneza poglądów, a nie ich treść. W strukturalnym sposobie rozumienia pojęcia „szkoły naukowe” uwypukla się to, że „[...] «szkoła» to grupa ludzi zajmujących się określoną problematyką wspólną, reprezentujących wyróżniającą się w jakiś sposób orientację teoretyczną i (lub) metodologiczną, pozostających w stosunkach oddziaływania wzajemnego, uznających autorytety tych samych osób, korzystających z podobnych wzorców postępowania badawczego itp." (Szacki 1975: 7).

3 W Przedmowie do tego tomu Jan Szczepański napisał że „[...] udoskonalenie metod ankietowych, a zwłaszcza szerokie stosowanie techniki wywiadu dla ustalenia postaw i opinii, postawiło niezwykle ostro zagadnienie, w jakiej mierze w sformułowaniach słownych badanych ludzi przejawiają się adekwatnie ich rzeczywiste postawy i opinie" (Szczepański 1966: 6) wyrażając tym samym nadzieję, że prace metodologiczne pozwolą poznawać i kontrolować wpływ czynników zakłócających zbieranie materiałów, chociaż zapewne bardziej wartościowe dla socjologii jako nauki byłoby wyeliminowanie tych zakłóceń: „Jest to także bardzo dawne marzenie badaczy zjawisk społecznych, żeby wypracować techniki i narzędzia badawcze pozwalające wyeliminować wszystkie przesłony wynikające czy to z natury ludzkiej, czy z natury faktów społecznych, istniejące między badaczem a faktami i modyfikujące czy też deformujące obraz tych faktów w świadomości badaczy" (Szczepański 1966:7-8). 
gów w pracach szkoły brali udział również ówcześni studenci socjologii ${ }^{4}$, którzy uczęszczali na zajęcia prowadzone przez profesorów oraz uczestniczyli w praktykach studenckich (np. w Dobrzelowie koło Bełchatowa), w czasie których wdrażano charakterystyczne dla łódzkiego podejścia badawczego kanony pracy terenowej i kontaktu z respondentami. Współpraca dwóch zespołów metodologów i stojących na ich czele socjologów owocowała podejmowaniem wspólnych badań, spotkaniami i naukowymi dyskusjami na temat projektów, koncepcji i rezultatów prób metodologicznych, a także publikacjami - w postaci kolejnych tomów Analiz i prób..., wydawanych zeszytów $Z$ metodologii i metodyki socjologicznych badań terenowych oraz artykułów publikowanych w czasopismach naukowych. Określenie początku działalności szkoły nie jest trudne, ale kłopotów nastręcza próba oznaczenia daty zakończenia jej trwania. Takich „końców” można wskazać co najmniej kilka: (1) początki lat 80. XX w., kiedy Jan Lutyński częściej w swej refleksji socjologicznej podejmował tematy społeczno-polityczne, a Zygmunt Gostkowski, który przeniósł się do Francji, gdzie został zatrudniony w UNESCO, poświęcał czas na zgłębianie zagadnienia stosowania wskaźników statystycznych, opisujących stan zasobów ludzi w krajach słabo rozwiniętych; (2) rok 1988, kiedy umarł Jan Lutyński; (3) początek lat 90., gdy na skutek oszczędności finansowych IFiS PAN zlikwidował swoje zamiejscowe ośrodki, w tym również łódzki Zakład Metodologii Badań Socjologicznych; (4) opublikowanie przez wychowanków tej szkoły lub ich uczniów artykułów dotyczących zagadnień podejmowanych przez jej twórców: w 1999 r. ukazał się artykuł Anny Kubiak oraz Ilony Przybyłowskiej, w którym autorki omawiają kwestie dotyczące klasyfikacji pytań kwestionariuszowych Jana Lutyńskiego, a całkiem niedawno, bo w 2015 r. artykuł na temat nowej klasyfikacji technik otrzymywania materiałów w socjologii (Krzewińska, Grzeszkiewicz-Radulska 2013); (5) opublikowanie XII tomu Analiz i prób technik badawczych w socjologii (Grzeszkiewicz-Radulska 2009). Chcąc w sposób jednoznaczny określić czas trwania szkoły, należałoby uznać za koniec aktywnej działalności nad wspólnymi projektami (a tym samym koniec łódzkiej szkoły metodologicznej sensu stricto) rok 1988, kiedy zmarł jej twórca - Jan Lutyński. Do przyjęcia tej daty skłania również fakt, że w latach 1966-1988 podejmowano najbardziej intensywne przedsięwzięcia badawcze, realizowano duży projekt we Włocławku i w Łodzi, opublikowano 6 tomów serii wydawniczej (łącznie z tomem piątym, prezentują-

4 Istotny jest fakt, że niektórzy z tych studentów jako późniejsi samodzielni badacze pozostali wierni założeniom i wskazówkom łódzkiej szkoły metodologicznej. W swojej pracy naukowej i realizowanych przez siebie projektach badawczych wprost odwoływali się - i czynią to nadal - do tradycji metodologicznej tódzkiej szkoły metodologicznej. Jedna z uczestniczek tych praktyk tak wspomina tamte „formujące” doświadczenia: „Jako studenci byliśmy uczeni bardzo odpowiedzialnego, świadomego i krytycznego podchodzenia do badań empirycznych. Takim «poligonem» były nasze praktyki studenckie w Bełchatowie w roku 1962 lub 1963, w momencie poprzedzającym intensywne uprzemysłowienie tego sennego wówczas miasteczka i jego rolniczego otoczenia" (http://polpan.org/wp-content/uploads/2014/04/ Wywiad_prof_Krystyna_Janicka.pdf). 
cym koncepcję procedur weryfikacyjnych, do którego treści będziemy odwoływać się w tym rozdziale).

$\mathrm{Na}$ wyjaśnienie zasługuje jeszcze kwestia związana z postacią mistrza w przypadku łódzkiej szkoły metodologicznej. Przyznając słuszność poglądowi Andrzeja P. Wejlanda, który Z. Gostkowskiemu przypisuje określenie pola badawczego socjologii empirycznej, ale zdecydowanie stwierdza, że „łódzka szkoła metodologiczna to szkoła Jana Lutyńskiego" (Wejland 2004: 210), uznajemy, że jej mistrzem był J. Lutyński. Na niego wskazują również inni uczniowie i współpracownicy obydwu socjologów. Nie umniejsza to jednak zasług Z. Gostkowskiego, który był inicjatorem, redaktorem i współredaktorem kolejnych tomów Analiz i prób technik badawczych $w$ socjologii.

To właśnie ta seria wydawnicza - nazwana przez nas „tubą” publikacyjną (Grzeszkiewicz-Radulska, Krzewińska 2015: 34) - pozwalała na prezentację odrębności metodologicznej łódzkich socjologów (spis tomów w zestawieniu poniżej) $)^{5}$. Chociaż poszczególne prace różnią się tematyką, sposobem strukturyzowania problemów i stylem pisania, to jednak pokazują odrębność tej grupy badaczy. Większość poruszanych tematów ma empiryczne zakotwiczenie w badaniach własnych lub w badaniach innych socjologów, nad którymi autor tekstu prowadzi pogłębione studia metodologiczne. Przeprowadzane przez autorów badania cechują się dociekliwością, podejmowaniem trudnych, czasochłonnych i pracochłonnych analiz. Łączy je wspólny background metodologiczny, wynikający z tego, że wszyscy badacze są absolwentami studiów socjologicznych w Uniwersytecie Łódzkim. To samo wykształcenie oznacza nie tylko wspólnych nauczycieli, lecz także czytane podczas studiów lektury, przyswojony warsztat metodologiczny, prowadzone wspólnie pierwsze wprawki badawcze, uczestnictwo w obozach naukowych, zbieranie materiałów podczas pracy przy realizowanych projektach. Tak kształtowana socjologiczna tożsamość nie miała zbyt wielu „konkurencyjnych” punktów odniesienia: dostępność zagranicznych prac metodologicznych była niewielka, a poza warszawskim zespołem Stefana Nowaka nie było w Polsce zespołów badawczych zainteresowanych przede wszystkim zagadnieniami metodologicznymi. To powodowało wtórne wzmocnienie tożsamości: badacze w swoich pracach metodologicznych odwoływali się przede wszystkim do tekstów kolegów z tej samej szkoły naukowej. W taki sposób kształtowało się podobieństwo poglądów w zakresie założeń teoretycznych i metodologicznych oraz podobieństwo zainteresowań naukowych.

5 Należy jednak podkreślić, że obydwie wspomniane serie wydawnicze - Analizy i próby... oraz Z zagadnień metodologicznych... - nie zawierają wszystkich prac socjologów z tódzkiej szkoły metodologicznej. Obok książek i artykułów zamieszczonych w tych dwóch cyklach, ogłoszono drukiem - co wylicza Krystyna Lutyńska - „[...] 20 książek (w tym 8 o charakterze podręcznikowym), nie licząc artykułów i studiów, które ukazały się zarówno w polskich, jak i zagranicznych czasopismach" (Lutyńska 1992: 199). 
TOM I - 1966 - Gostkowski Zygmunt (red.): Analizy i próby technik badawczych w socjologii. Wrocław-Warszawa-Kraków: Ossolineum, 377 s. (11 artykułów)

TOM II - 1968 - Gostkowski Zygmunt, Lutyński Jan (red.): Analizy i próby technik badawczych $w$ socjologii. Wrocław-Warszawa-Kraków: Ossolineum, 292 s. (9 artykułów)

TOM III - 1970 - Gostkowski Zygmunt, Lutyński Jan (red.): Analizy i próby technik badawczych $w$ socjologii. Wrocław-Warszawa-Kraków: Ossolineum, 416 s. (10 artykułów)

TOM IV - 1972 - Gostkowski Zygmunt, Lutyński Jan (red.): Analizy i próby technik badawczych $w$ socjologii. Wywiad kwestionariuszowy $w$ świetle badań metodologicznych. Wrocław-Warszawa-Kraków-Gdańsk: Ossolineum, 534 s. (16 artykułów)

TOM V - 1975 - Gostkowski Zygmunt, Lutyński Jan (red.): Analizy i próby technik badawczych w socjologii. Studia pilotażowe i analizy weryfikacyjne. Wrocław-Warszawa-Kraków-Gdańsk: Ossolineum, 598 s. (15 artykułów)

TOM VI - 1986 - Lutyńska Krystyna, Lutyński Jan (red.): Analizy i próby technik badawczych $w$ socjologii. Daniłowicz Paweł, Sztabiński Paweł B.: Zmienne osobowe w badaniach socjologicznych. Analizy weryfikacyjne. Wrocław-Warszawa-Kraków-Gdańsk-Łódź: Ossolineum, 259 s. (monografia)

TOM VII - 1989 - Gostkowski Zygmunt (red.): Analizy i próby technik badawczych w socjologii. Społeczne obrazy i stereotypy chłopa, urzędnika i robotnika. Studia eksploracyjne. Wrocław-Warszawa-Kraków-Gdańsk-Łódź: Ossolineum, 427 s. (8 artykułów)

TOM VIII - 1990 - Gostkowski Zygmunt (red.): Analizy i próby technik badawczych $w$ socjologii. Wrocław-Warszawa-Kraków: Ossolineum, 286 s. (7 artykułów)

TOM IX - 1992 - Gostkowski Zygmunt (red.): Analizy i próby technik badawczych $w$ socjologii. Problemy humanizacji procesu badawczego. Warszawa: Wydawnictwo IFiS PAN, 166 s. (7 artykułów)

TOM X - 2001 - Gostkowski Zygmunt, Daniłowicz Paweł (red.): Analizy i próby technik badawczych $w$ socjologii. Sondaże opinii społecznej. Samowiedza współczesnych społeczeństw. Łódź: Wydawnictwo IFiS PAN, 260 s. (8 artykułów) 
TOM XI - 2006 - Gostkowski Zygmunt, Kubiak Anna (red.): Analizy i próby technik badawczych $w$ socjologii. Krzewińska Aneta, O socjologicznym wywiadzie kwestionariuszowym: psychologia poznawcza Norberta Schwarza i jej badawcze zastosowanie $w$ warunkach polskich. Łódź: ŁTN, 245 s. (monografia)

TOM XII - 2009 - Kubiak Anna (red.): Analizy i próby technik badawczych w socjologii. Grzeszkiewicz-Radulska Katarzyna, Respondenci niedostępni w badaniach sondażowych. Łódź: Wydawnictwo UŁ, 384 s. (monografia)

\subsection{Przedmiot zainteresowań socjologów z tódzkiej szkoły metodologicznej}

Przedmiotem zainteresowania socjologów skupionych w łódzkiej szkole metodologicznej była, co oczywiste, metodologia badań społecznych, ze szczególnym naciskiem na metody używane w socjologii. Jednak nie wszystkie zagadnienia metodologiczne były równie często podejmowane i szczegółowo badane. Można zatem wyróżnić te dominujące, będące przedmiotem analiz i studiów empirycznych.

Próbę stworzenia takiej problemowej charakterystyki orientacji metodologicznych łódzkiego ośrodka podjęli J. Lutyński (1990, 1993) i Krystyna Lutyńska (1992). Każde z tych opracowań w trochę inny sposób ujmuje zainteresowania łódzkich metodologów, a różnic tych należy upatrywać przede wszystkim w tym, jaki czas i jaką grupę badaczy wzięto pod uwagę. Jan Lutyński w obydwu swoich artykułach opisuje dokonania łódzkiej szkoły metodologicznej i pokrótce odnosi się do badań prowadzonych przez socjologów z łódzkiego ośrodka, podczas gdy K. Lutyńska ogniskuje swoją uwagę wokół działalności Zakładu Metodologii Badań Socjologicznych IFiS PAN.

Zainteresowania pracowników tego zakładu (częściowo podzielane również przez pracowników Uniwersytetu Łódzkiego, którzy stanowili drugą „gałąź” łódzkiej szkoły metodologicznej) oscylują wokół - jak pisze K. Lutyńska - trzech zasadniczych grup zagadnień, do których należą: „1. metodologia i metodyka badań socjologicznych w Polsce (przede wszystkim badań kwestionariuszowych); 2. postrzeganie grup i kategorii społecznych; 3. problematyka konstrukcji wskaźników i ich wykorzystania w pozaankietowych badaniach zależności między zmiennymi" (1992). Najważniejsze, będące przedmiotem najobszerniejszych studiów i publikacji są zagadnienia związane z badaniami socjologicznymi, a w szczególności z wywiadami kwestionariuszowymi (chociaż i z samowypełnianymi ankietami), które poddawano analizom, dogłębnie je krytykując, ale również próbując wypracować pewne procedury podnoszące ich jakość. Ta szczególna uwaga skupiona na tego typu badaniach wiązała się z żywionym już na przełomie lat 60. i 70. przekona- 
niem, że badania surveyowe ${ }^{6}$, w których materiały zbierane są za pomocą kwestionariuszy, będą się prężnie rozwijały. Podjęte w tych czasach prace dotyczyły m.in. akulturacji badań sondażowych, społecznych uwarunkowań sytuacji wywiadu, wartości danych uzyskiwanych w trakcie takich badań, efektu ankieterskiego, aspektów etycznych, badań pilotażowych itp. Szczególnie należy podkreślić fakt, że problematyka związana z metodologią i metodyką badań socjologicznych była obecna przez cały czas istnienia Zakładu. Drugi zbiór zagadnień, który pojawił się później, był związany z badaniem sposobu postrzegania grup i kategorii społecznych. Realizowano wtedy projekt dotyczący stereotypów i obrazów społecznych chłopa, robotnika i urzędnika powiązany z refleksją metodologiczną na temat stosowanych technik i metod do badania stereotypów. Trzecia grupa zagadnień, którymi się zajmowano, obejmowała przede wszystkim dane pozaankietowe i stanowiła wynik współpracy Z. Gostkowskiego z UNESCO. Przedmiotem analiz stały się wówczas wskaźniki (odnoszące się do zasobów ludzkich, będących czynnikami społeczno-gospodarczymi w badaniu krajów słabo rozwiniętych, nierównomierności w rozwoju społecznym i kulturalnym, poziomu wykształcenia, działalności badawczo-naukowej i technologicznej), sposoby konstrukcji tych wskaźników i możliwości ich wykorzystania w międzynarodowych badaniach porównawczych. Jeśli na łódzką szkołę metodologiczną spojrzymy szerzej, czyli weźmiemy pod uwagę orientację teoretyczno-metodologiczną badaczy - jej twórców, J. Lutyńskiego i Z. Gostkowskiego, a także ich współpracowników i uczniów - to przekonamy się, że prowadzona przez nich naukowa refleksja jest najbliższa rozważaniom w nurcie scjentystycznym (co dostrzegał również Lutyński). Scjentystyczne podejście przejawia się w próbach uporządkowania, ujednolicania, kontrolowania, udoskonalania procedury badawczej (w szczególności w stosowaniu standaryzowanych technik) i włącza się w refleksję związaną z odrębnością, istnieniem osobliwości nie dających się pominąć w naukach społecznych ${ }^{7}$. Biorąc pod uwagę wprowadzony przez E. Mokrzyckiego podział na metodologię wewnętrzną i zewnętrzną (Mokrzycki 1980: 149-150), można stwierdzić, że badania prowadzone w łódzkiej szkole metodologicznej wpisują się w nurt dociekań związanych z szukaniem rozwiązań, tropów i podpowiedzi w obrębie własnej dyscypliny naukowej. Prace łódzkich badaczy niewątpliwie należą do metodologii wewnętrznej.

6 Należy podkreślić, że łódzcy metodolodzy byli dość krytycznie nastawieni do surveyów, ale to nastawienie - zdaniem Jana Lutyńskiego - bardziej krytyczne, niż gdzie indziej, „[...] przyczyniło się w jakimś stopniu do podwyższenia poziomu tego rodzaju badań w Łodzi w stosunku do ogólnokrajowego standardu w zakresie zdobywania danych" (Lutyński 1993: 19).

7 Do osobliwości nauk społecznych Stanisław Ossowski zaliczył: „[...] 1) z dawna zaobserwowany wpływ rezultatów badań na rzeczywistość, do której wnioski z badań mają się odnosić, 2) bezpośredni wpływ samych czynności badawczych na badaną rzeczywistość, 3) konflikt pomiędzy postulatem systematyczności badań i postulatem ubiegania się o wnioski ogólne, nie ograniczone wyznacznikami historycznymi, 4) konflikt pomiędzy ograniczeniem się do metod standaryzowanych a miarodajnością wskaźników i subtelnością problematyki, 5) udział doświadczenia wewnętrznego w praktyce badawczej” (Ossowski 2001: 181). 
Najważniejszym elementem badań socjologicznych jest, dla przedstawicieli łódzkiej szkoły, proces powstawania danych i jego poszczególne etapy. Dominującą procedurę badawczą, pozwalającą na studia nad tym procesem, stanowi pewna odmiana metodologii, metodologia empiryczna, zakładająca „oparcie się w próbach doskonalenia warsztatu badawczego na specjalnie prowadzonych badaniach o charakterze metodologicznym" (Lutyński 1990). Techniką badawczą najczęściej poddawaną analizie przez łódzkich socjologów był wywiad kwestionariuszowy. Uwzględniano czynniki wpływające na dane uzyskiwane dzięki stosowaniu go, wśród których znalazły się: sytuacja społeczno-polityczna i gospodarcza kraju, sytuacje różnych kategorii respondentów, zachowanie i błędy popełniane przez ankieterów, cechy sytuacji wywiadu itp. Oprócz tego dokonywano porównań technik badawczych (wywiadów kwestionariuszowych i technik ankietowych) oraz różnych typów pytań (otwartych i zamkniętych). Istotny wydawał się także problem oceny wartości danych uzyskanych za pomocą różnych technik badawczych. Aby taką ocenę przeprowadzić, opracowano dwie procedury:

- weryfikację zewnętrzną, bazującą na weryfikacji dokumentalnej i pogłębionym wywiadzie weryfikacyjnym;

- weryfikację wewnętrzną, odnoszącą się do oceny procesu badawczego ${ }^{8}$.

Ostatnie akapity odnoszą się do prób określenia pola zainteresowań łódzkich metodologów, podejmowanych przez współtwórcę łódzkiej szkoły metodologicznej oraz jej wieloletnią współpracownicę. Można więc przyjąć, że to podsumowania dokonane od środka. Wydaje się jednak zasadne przeprowadzenie takiej oceny z pozycji nieco bardziej zewnętrznych. W artykule $O$ tym, jak napisać biografię naukowa (łódzka szkoła metodologiczna) określiłyśmy swoje miejsce/stanowisko wobec łódzkiej szkoły metodologicznej:

Zatem jesteśmy pracownicami Katedry Metod i Technik Badań Społecznych, w której w różnych okresach pracowali twórcy szkoły Lutyński i Gostkowski, i która jest głównym spadkobiercą zarówno myśli, jak i „ducha” łódzkiej szkoły metodologicznej. Jesteśmy związane z miejscem, w którym nadal zawodowo pracują: bezpośrednia uczennica Jana Lutyńskiego, dwie osoby, których promotorem rozpraw doktorskich był Zygmunt Gostkowski, a w odbywających się zebraniach naukowych uczestniczą socjologowie związani z mistrzem Lutyńskim. [...] Co więcej, jesteśmy „pośrednimi uczennicami” Lutyńskiego i Gostkowskiego - wszak opiekunami naszych rozpraw doktorskich byli ich uczniowie. Nasza metodologiczna „socjalizacja” przebiegała wśród uczniów szkoły i na ich tekstach naukowych. A wreszcie, przygotowane przez nas doktoraty zostały opublikowane w kolejnych tomach Analiz i prób... [Krzewińska 2006, Grzeszkiewicz-Radulska 2009] - to nie tylko uznanie poziomu naszej dojrzałości intelektualnej za odpowiedni, ale może to także - i przede wszystkim - symboliczne włączenie do wspólnoty. [...]. Jesteśmy zatem ulokowane wewnątrz badanego układu, a gdyby próbować dookreślać miejsce, to raczej byłybyśmy na obrzeżach centrum (Grzeszkiewicz-Radulska, Krzewińska 2015: 34).

Mimo wszystko jednak naszą perspektywę uznajemy za zewnętrzną.

8 Więcej na ten temat piszemy w kolejnym podrozdziale. 
Do przeprowadzenia tej analizy można zapewne użyć różnych wymiarów. My podzielimy aktywność badawczą szkoły na dwie zasadnicze kategorie: ogólną i szczegółową, a w ich obrębie wyszczególnimy podkategorie. Ogólna to badania ilościowe i jakościowe, a w szczegółowej znajdą się odniesienia do elementów metodyki badań, takich jak np. stosowanie danej techniki otrzymywania materiałów, warunki stosowania danej techniki oraz tematyka konkretnych badań (np. badanie stereotypów, badanie konsumpcji kulturalnej). W tej stosunkowo prostej analizie zawartości posłużymy się artykułami opublikowanymi w dwóch seriach wydawniczych: Analizach i próbach technik badawczych w socjologii ${ }^{9}$ oraz w $\mathrm{Za}$ gadnieniach $z$ metodologii i metodyki socjologicznych badań terenowych. Zaznaczamy, że dany artykuł może być jednocześnie zaliczony do więcej niż jednej kategorii, gdy opisane są w nim np. dwie techniki: ilościowa i jakościowa (weryfikacja danych pochodzących $\mathrm{z}$ wywiadów kwestionariuszowych za pomocą obserwacji uczestniczącej) lub gdy obok dyrektyw dotyczących sposobów prowadzenia badań z wykorzystaniem danej techniki podejmowana jest również pogłębiona refleksja metodologiczna, pozwalająca określić granice stosowalności danej techniki.

Spójrzmy na tabele 1-4, pokazujące wyniki przeglądu, zaczynającego się od serii wydawniczej Analizy i próby technik badawczych w socjologii, w której zdecydowanie przeważają artykuły prezentujące podejście ilościowe w badaniach socjologicznych. Różnica pomiędzy liczbą doniesień naukowych o metodach/technikach jakościowych w stosunku do ilościowych jest jak 1 do 4.

Tabela 1. Opis rodzaju metod $w$ artykułach zamieszczonych w tomach I-X Analiz i prób technik badawczych w socjologii

\begin{tabular}{|c|c|}
\hline Metody & Liczba artykułów \\
\hline Ilościowe & 82 \\
\hline Jakościowe & 20 \\
\hline Razem & 102 \\
\hline
\end{tabular}

Źródto: opracowanie własne.

Jeśli weźmiemy pod uwagę tematykę artykułów, to przeważają te prezentujące perspektywę metodologiczną i jest ich prawie dwa razy więcej niż artykułów odnoszących się do samej metodyki prowadzenia badań społecznych. Należy również odnotować, że często autorzy nie poprzestają jedynie na przekazaniu zaleceń metodycznych, ale formułują wnioski o większym stopniu ogólności, podejmując refleksję metodologiczną, odnoszącą się np. do warunków stosowania danej techniki badawczej.

9 Z analizy zostaną wyłączone dwa ostatnie tomy, ponieważ zostały opublikowane po długiej przerwie, a dodatkowo nie są przez nas zaliczane do publikacji wchodzącej do dorobku tódzkiej szkoły metodologicznej, chociaż zdecydowanie prezentują „ducha” tej szkoły. 
Tabela 2. Tematyka artykułów opublikowanych w tomach I-X Analiz i prób technik badawczych w socjologii

\begin{tabular}{|c|c|}
\hline Temat artykułu & Liczba artykułów \\
\hline Metodyka & 44 \\
\hline Metodologia & 79 \\
\hline Inny & 45 \\
\hline Razem & 168 \\
\hline
\end{tabular}

Źródto: opracowanie własne.

Analiza artykułów zawartych w zeszytach naukowych $Z$ metodologii i metodyki socjologicznych badań terenowych potwierdziła zaobserwowaną i opisaną tendencję odnoszoną do Analiz i prób technik badawczych w socjologii, dotyczącą rodzaju badań ilościowych i jakościowych. Także w tej serii wydawniczej dominują techniki ilościowe, przy czym artykułów im poświęconych jest trzy razy więcej niż odnoszących się do badań jakościowych.

Tabela 3. Opis rodzaju metod $w$ artykułach zamieszczonych w tomach I-X

Z metodologii i metodyki socjologicznych badań terenowych

\begin{tabular}{|c|c|}
\hline Metody & Liczba artykułów \\
\hline Ilościowe & 39 \\
\hline Jakościowe & 13 \\
\hline Razem & 52 \\
\hline
\end{tabular}

Źródto: opracowanie własne.

Inaczej wygląda problematyka artykułów, bowiem przeważają te, które prezentują refleksję metodyczną, natomiast odnoszących się do warstwy metodologicznej jest mniej i - co warte podkreślenia - w 13 przypadkach na 22 współwystępuje ona $\mathrm{z}$ instrukcjami, rozważaniami i dyrektywami metodycznymi.

Tabela 4. Tematyka artykułów opublikowanych $w$ tomach I-X $Z$ metodologii i metodyki socjologicznych badań terenowych

\begin{tabular}{|c|c|}
\hline Temat artykułu & Liczba artykułów \\
\hline Metodyka & 29 \\
\hline Metodologia & 22 \\
\hline Inny & 12 \\
\hline Razem & 63 \\
\hline
\end{tabular}

Źródło: opracowanie własne. 
Gdyby próbować podsumowywać kolejne tomy Analiz i prób... ${ }^{10}, \mathrm{z}$ jednoczesnym wskazaniem podejmowanych $\mathrm{w}$ nich tematów przewodnich, można stwierdzić, że tom pierwszy „[...] koncentrował się na problemach wywiadu” (Gostkowski, Lutyński 1968: 5). Drugi tom był poświęcony przede wszystkim ankiecie wypełnianej, gdyż ta technika, zdaniem redaktorów tomu, nie stała się do momentu jego wydania przedmiotem analiz metodologicznych, chociaż była wtedy dość często stosowana. W kolejnej publikacji z tej serii podjęto refleksję metodologiczną nad spójnością lub rozbieżnością modelu sytuacji badawczej projektowanej przez badacza, przełożeniem tej sytuacji na rzeczywistość oraz wiarygodnością odpowiedzi udzielonych przez respondentów w trakcie badań. Miało to oddźwięk w tytułach dwóch części, z których pierwszy brzmiał: Projektowane a rzeczywiste zachowania respondentów i ankieterów w sytuacji wywiadu, a drugi: Problemy oceny wiarygodności danych $z$ wywiadów $w$ różnych sytuacjach społecznych. W tomie czwartym uwaga autorów artykułów skupiała się na problematyce wywiadu kwestionariuszowego, przy czym w pierwszej części tomu opublikowano materiały dotyczące ogólnych problemów tego typu wywiadu, a część druga zawiera studia prezentujące wywiady prowadzone $\mathrm{z}$ wybranymi kategoriami respondentów. Tom piąty - z perspektywy podejmowanej w tym opracowaniu problematyki najważniejszy - dotyczy analiz weryfikacyjnych. Kolejny tom ma charakter dwuautorskiej monografii, w której Paweł Daniłowicz i Paweł B. Sztabiński, kontynuując refleksje dotyczące weryfikacji, zajmują się doskonaleniem narzędzi badawczych, ze szczególnym uwzględnieniem danych metryczkowych. Monotematyczny tom siódmy zawiera artykuły z kręgu metodologicznej problematyki badania obrazów społecznych i stereotypów: chłopów, robotników oraz urzędników. „Charakter tych ośmiu studiów różni się znacznie od prac zawartych w poprzednich tomach Analiz i prób...; są to bowiem studia zarówno merytoryczne, jak i metodologiczne; można by je określić mianem studiów czy badań eksploracyjnych" (Gostkowski 1989: 5). Tom ósmy poświęcony jest procesowi badawczemu, na który patrzy się jak na pewien proces społeczny, wiarygodności uzyskiwanych w tym procesie danych oraz skalom i wskaźnikom, które konstruuje się na podstawie uzyskanego materiału. Dziewiąty tom ukazuje kwestie humanizacji procesu badawczego, przy czym w pierwszej części tego opracowania podejmuje się ogólną refleksję na temat humanizacji, podmiotowości i partnerstwa między badaczem $\mathrm{i}$ badanym $\mathrm{w}$ badaniach socjologicznych, a w drugiej prezentuje się propozycje

10 Podsumowanie wątków problematycznych podejmowanych w łódzkiej szkole metodologicznej, ograniczyłyśmy do serii Analizy i próby..., pomijając zupełnie drugi cykl wydawniczy Z metodologii... z dwóch podwodów: pierwsza z wymienionych tu serii jest ważniejsza, zawiera bardziej reprezentatywne, istotniejsze dla socjologów wchodzących w skład tej szkoły prace, a po drugie kolejne tomy zeszytów $Z$ metodologii... rzadko kiedy są spójne tematycznie. Krystyna Lutyńska w trakcie przeprowadzanego z nią wywiadu swobodnego stwierdziła nawet, że publikowano tam prace, które niejako „nie zmieścity się” w Analizach i próbach... Należy jednak podkreślić, że tematyka artykułów opublikowanych w zeszytach naukowych Z metodologii... jest identyczna z opisywaną tu problematyką. 
technik i zabiegów badawczych, dzięki którym te humanizujące postulaty można by realizować. Ostatnia część serii jest zbiorem artykułów odnoszących się do metodologicznych problemów, generowanych podczas realizacji badań oraz sposobów prezentacji wyników sondaży w prasie.

Dość zbieżny - również problemowy - jest sposób zaprezentowania tematyki poruszonej na 3,5 tys. stron serii wydawniczej Analizy i próby... oraz XI tomu tej serii autorstwa Z. Gostkowskiego, który pisze:

W kolejnych tomach starano się w sposób bardziej pogłębiony przedstawić między innymi: 1. analizy weryfikacyjne takie, jak ocena i porównanie rezultatów badawczych opartych na danych uzyskiwanych za pomocą różnych technik [...], 2. społeczną sytuację wywiadu [...], 3. ocenę wiarygodności danych odnoszących się do zmiennych osobowych respondentów, uzyskiwanych drogą wywiadów [...], 4. studia nad pilotażem badawczym [...], 5. analizy zachowań respondentów i ankieterów w sytuacji wywiadu [...], 6. Specyfikę ankiety wypełnianej przez respondentów [...], 7. Kulturowy i społeczny kontekst wywiadu socjologicznego [...], 8. Wiarygodność uzyskiwanych w wywiadzie informacji pierwotnych oraz skal i wskaźników konstruowanych na ich podstawie [...], 9. Wyniki studiów eksploracyjnych nad społecznymi stereotypami chłopa, urzędnika i robotnika w Polsce [...], 10. Kwestia humanizacji poznawczej i moralnej procedur badawczych stosowanych w socjologii, 11. Czy wreszcie sondaże opinii jako zjawisko społeczne w naszym kraju [...] (Gostkowski 2006: 9-10).

Niezależnie od sposobu analizowania treści opracowanych w łódzkiej szkole metodologicznej, zawsze w takim zestawieniu problemowym znajdą się kwestie związane z wartością danych uzyskiwanych w badaniach socjologicznych i technikami weryfikacji tych danych. Założeniom metodologicznym oraz procedurom weryfikacji danych będzie poświęcona dalsza część tego rozdziału i pozostała część tomu.

\subsection{Analizy weryfikacyjne - koncepcja teoretyczna Jana Lutyńskiego}

Jan Lutyński w przywoływanym już tekście podsumowującym prace metodologiczne prowadzone $\mathrm{w}$ łódzkim środowisku socjologicznym napisał, że jednym z "niedomagań socjologii” (Lutyński 1998: 28) jest brak wypracowanych metod, służących do oceny wartości otrzymywanych w trakcie badań danych. Odróżnia to socjologię od innych nauk humanistycznych, w tym psychologii i historii, które takie metody wypracowały. Badacz proponuje zatem, by wypracować na gruncie socjologii metody, za pomocą których będzie można przeprowadzać weryfikację zewnętrzną lub wewnętrzną, przy czym proponuje, by weryfikacją nazywać 
wszystkie „(a)nalizy zmierzające do sformułowania jakiejkolwiek oceny wiarygodności wyników liczbowych" (Lutyński 1994: 21211).

Weryfikacja zewnętrzna - pisząc w dużym skrócie - ma polegać na zestawieniu informacji uzyskiwanych od respondentów w toku badań (np. w trakcie prowadzonych wywiadów kwestionariuszowych) z informacjami pochodzącymi z innych źródeł, które powinny być bardziej wiarygodne, pewniejsze niż badanie oparte na interrogacji. Dzięki temu socjolog może zarejestrować pojawienie się błędu indywidualnego, będącego nieprawdziwą jednostkową informacją. Po zsumowaniu wszystkich indywidualnych błędów będzie można obliczyć, ile w sumie osób w danym badaniu podało nieprawdziwe informacje, czyli oszacować wielkość błędu brutto. Jeżeli informacje podawane przez ankietowanego mogą być związane z zawyżaniem lub zaniżaniem pewnych wartości (np. wysokości zarobków, czasu przebywania na zwolnieniu lekarskim itp.), można obliczyć tzw. błąd netto, będący rezultatem znoszenia się błędów indywidualnych. Z taką sytuacją mamy do czynienia wtedy, gdy część badanych zawyżyłaby swoje zarobki, a część podała zbyt niską ich wartość. Różnica między błędami brutto i netto została nazwana błędem wyrównanym, „[...] który czasami może być bardzo duży, mimo że błąd netto jest minimalny. Błąd wyrównany wpływa w znacznym stopniu na wysokość, a nawet kierunek (jeśli jest duży) korelacji danej zmiennej z innymi" (Lutyński 1990: 29). Takie obliczenia wielkości poszczególnych błędów można robić tylko w sytuacji, gdy informacje zewnętrzne służące do weryfikacji (czyli weryfikatory) są pewne, tzn. zgodne z prawdą. Innym sposobem weryfikacji zaliczanym również do kategorii zewnętrznej może być analiza korelacji, kiedy badacz sprawdza, czy weryfikowane zmienne korelują z innymi, a na podstawie wcześniej przeprowadzonych badań wiadomo, że takie korelacje występują oraz czy dane dotyczące weryfikatora (drugiej zmiennej wprowadzonej do analiz korelacyjnych) są pewne. Celem weryfikacji zewnętrznej jest sprawdzenie wartości otrzymanych danych, a także ocena narzędzi, za pomocą których zebrano te dane.

Weryfikacja wewnętrzna skupia się na ocenie procesu otrzymywania materiałów bez odwoływania się do jakichkolwiek weryfikatorów zewnętrznych. Przyjmowane w tej perspektywie założenie jest następujące: „jeśli proces formowania się informacji był prawidłowy, wartościowy musi być i jego rezultat, to jest sama informacja” (Lutyński 1990: 32). Aby proces zdobywania danych mógł być poddany skrupulatnej analizie, należy zbudować model stanowiący wzór prawidłowego przebiegu procesu uzyskiwania odpowiedzi od respondenta na pytanie zadane podczas badania. Jan Lutyński opracował trzy koncepcje pytania jako narzędzia badawczego: testową, wskaźnikową oraz tradycyjno-informacyjną (Lutyński 1978; Kubiak, Przybyłowska 1999), a ich szczegółowa analiza i krytyka pozwoliły mu na wypracowanie tzw. rozszerzonej informacyjnej koncepcji pytania jako narzędzia, o czym dokładniej piszemy w dalszej części tego rozdziału.

11 Przywoływany tutaj artykuł został po raz pierwszy opublikowany pod tym samym tytułem w V tomie Analiz i prób...(Lutyński 1975). 


\subsubsection{Założenia metodologiczne prowadzenia analiz weryfikacyjnych}

U podstaw analiz weryfikacyjnych, szczególnie w odniesieniu do danych uzyskiwanych za pomocą wywiadu kwestionariuszowego, leży kilka założeń. Po pierwsze, źródeł błędów dotyczących całej zbiorowości należy upatrywać w błędach jednostkowych pochodzących od pojedynczych respondentów. Specyfiką badań prowadzonych $\mathrm{z}$ wykorzystaniem wywiadów kwestionariuszowych jest bowiem to, że na podstawie informacji od pojedynczych (bardzo często losowo dobranych) osób staramy się wyprowadzić wnioski (uogólniając te jednostkowe wyniki) o populacji, której jednostka jest reprezentantem. Po drugie, rezultaty badań często obarczone są błędami o charakterze systematycznym i związane są z powtarzaniem tych samych czynności/poszukiwań. Co więcej, nie da się ich wyeliminować przy użyciu odpowiednich procedur statystycznych, jak np. w naukach przyrodniczych. Po trzecie, inaczej niż w psychologii (szczególnie w stosowanych przez nią testach), w socjologii jedna poszukiwana informacja związana jest najczęściej z pojedynczym pytaniem, a nie z baterią pytań testowych, których wynik się zlicza. Socjolog ma zazwyczaj do czynienia $\mathrm{z}$ takimi narzędziami badawczymi, w których pojedyncze pytanie związane jest $\mathrm{z}$ pojedynczą poszukiwaną informacją $\mathrm{w}$ oderwaniu od innych odpowiedzi na pozostałe pytania zawarte w narzędziu. Pociąga to za sobą jeszcze taką niedogodność, że każde z pytań kwestionariusza może być obarczone innym błędem (zniekształceniem), a więc trudno jest opracować jedną uwspólnioną, zbiorczą ocenę całego narzędzia w badaniach socjologicznych, podczas gdy taką ocenę można opracować dla testów psychologicznych, w skład których wchodzą poszczególne pytania (itemy). Po czwarte, wywiady kwestionariuszowe dają możliwość gromadzenia informacji nie ograniczając się tylko do odpowiedzi na poszczególne pytania, ale dzięki obecności ankietera można również analizować sam proces udzielania odpowiedzi, a nawet szerzej - społeczną sytuację wywiadu. I wreszcie, po piąte, niektóre informacje pochodzące $\mathrm{z}$ wywiadów kwestionariuszowych można również zdobywać, posługując się innymi technikami otrzymywania materiałów, czy wręcz innymi źródłami, np. podczas obserwacji uczestniczących, samowypełnianych ankiet, analizy dokumentów osobistych itp. Niektóre z tych alternatywnych sposobów pozwalają na zdobycie danych lepszej jakości, a za użyciem wywiadów kwestionariuszowych przemawia przede wszystkim fakt, że stosując je można w dość krótkim czasie przebadać stosunkowo dużą liczbę respondentów, uzyskując od nich różnorodne informacje.

W wyniku analizy tych pięciu opisanych założeń zostały opracowane dwie metody analiz weryfikacyjnych, które omówimy w kolejnych podrozdziałach. 


\subsubsection{Weryfikacja zewnętrzna - procedury, metody, ograniczenia}

Należy zacząć od tego, że weryfikację zewnętrznąa ${ }^{12}$ zastosowano w łódzkiej szkole metodologicznej w kilku badaniach metodologicznych, weryfikując informacje:

- dotyczące wizyt w poradniach rejonowych celem uzyskania porady lekarskiej uzyskane od 635 osób (Lutyńska, Szeszenia 1972);

- na temat form uczestnictwa w kulturze (dane od 180 badanych) (Stefanowska 1986);

- o zarobkach (dane od 892 osób pochodzące z kilku badań) (Lutyńska 1975);

- dane osobowe (o 600 osobach) dotyczące m.in. wykształcenia respondentów oraz ich współmałżonków, wieku i wykonywanego zawodu (Daniłowicz, Sztabiński 1986);

- o osobach skazanych za przestępstwa (Pełka-Sługocka 1970).

W większości badań - poza dotyczącymi uczestnictwa w kulturze, w których jako metodę weryfikacyjną zastosowano ukrytą obserwację - weryfikatorami były dane zawarte w dokumentach. Badacze z łódzkiego ośrodka przeprowadzili dwa metodologiczne badania, których celem było sprawdzenie i ocena stosowanych metod weryfikacyjnych opartych na wykorzystaniu wywiadów kwestionariuszowych. Faza terenowa pierwszego badań miała miejsce we Włocławku, latem 1973 r., choć prace konceptualizacyjne rozpoczęto już rok wcześniej. Drugie badania odbyły się w Łodzi w 1976 r.

Wyróżniono trzy typy analiz weryfikacyjnych: typ 1 - z zastosowaniem pewnego (wiarygodnego) sposobu otrzymywania danych; typ 2 - wykorzystujące korelacje danych; typ 3 - oparte na porównywaniu wyników niepewnych. Podstawą do ich wyróżnienia było spełnianie bądź niespełnianie dwóch warunków: „1. (i)nformacje uzyskane różnymi drogami odnoszą się do jednostek badania z tej samej zbiorowości, zidentyfikowanych ponadto przez badacza; 2 . są to informacje analogiczne pod względem treści, tj. stanowią one rozstrzygnięcie tych samych pytań (oczywiście odpowiedzi udzielane na te pytania w odniesieniu do danej jednostki mogą być różne)" (Lutyński 1994: 221). Jeśli odniesiemy te warunki do typów obserwacji, to wyniki powiązań między nimi można zaprezentować w postaci tabelarycznej (tabela 5).

Analizy weryfikacyjne $z$ zastosowaniem pewnego sposobu otrzymywania danych są - zdaniem J. Lutyńskiego - najbardziej cenne. Stanowią rodzaj weryfikacji, w której danym zapisanym w wypełnionych wywiadach kwestionariuszowych towarzyszą informacje zebrane za pomocą innych metod, z innych źródeł, ale odnoszące się do tych samych jednostek badania. Oto kilka przykładów: deklaracjom na temat zażywania substancji psychoaktywnych będą towarzyszyły analizy chemiczne krwi, moczu itp.; odpowiedzi, w których respondent podaje

12 Przykłady weryfikacji zewnętrznej, prowadzonej w badaniach we Włocławku, zostały opisane przez J. Koniarka w artykule Weryfikacja zewnętrzna informacji uzyskanych w wywiadzie kwestionariuszowym (1975). 
wysokość zarobków zestawia się z listami płac uzyskanymi od pracodawcy. Tego typu analizy weryfikacyjne pozwalają na ocenę, w jakiej liczbie jednostek badania uzyskaliśmy błędne informacje (czyli np. ile osób podało nieprawdziwą wysokość zarobków), a także - jeśli pozwala na to skala, na której dokonywany jest pomiar jak duży jest każdy błąd (czyli o ile zadeklarowane wynagrodzenie różni się od rzeczywistych zarobków). Dlatego właśnie można obliczyć błędy ${ }^{13}$ : brutto (całkowity popełniony błąd dla całej zbiorowości bez uwzględnienia kierunku odchylenia), netto (suma błędów indywidualnych z uwzględnieniem kierunku) oraz wyrównane (różnica między błędem netto i brutto).

Tabela 5. Typy analiz weryfikacji zewnętrznej

\begin{tabular}{|c|c|c|}
\hline \multirow{2}{*}{$\begin{array}{c}\text { Typ weryfikacji } \\
\text { zewnętrznej }\end{array}$} & $\begin{array}{c}|c| \\
\text { Warunki, które muszą być spełnione w poszczególnych typach } \\
\text { analizy weryfikacyjnej }\end{array}$ \\
\cline { 2 - 3 } & $\begin{array}{c}\text { informacje odnoszą się } \\
\text { z tej samej zbiorowości }\end{array}$ & $\begin{array}{c}\text { informacje są analogiczne } \\
\text { pod względem treści }\end{array}$ \\
\hline Typ 1 & spełnia & spełnia \\
\hline Typ 2 & nie spełnia & spełnia \\
\hline Typ 3 & spełnia & nie spetnia \\
\hline
\end{tabular}

Źródło: opracowanie własne.

Analizy wykorzystujące korelacje danych nie pozwalają na obliczenie wielkości błędu, który popełniono, gromadząc dane z wykorzystaniem do tego wywiadów kwestionariuszowych. W tym przypadku wynik dotyczący występowania i rozkładu jakiejś cechy w zbiorowości ocenia się, korelując ją z inną zbadaną cechą. Sensowność tych analiz jest gwarantowana przez to, że według wcześniej posiadanej wiedzy korelacja ta występuje. Wiedza o tym nie jest bardzo dokładna, więc wykorzystując ją można określić, czy błąd został popełniony, ale niemożliwe jest oszacowanie wielkości tego błędu. Możliwe staje się sformułowanie wniosków o następującej treści: „[...] wystąpiła oczekiwana korelacja, to prawdopodobnie znaczna część zaklasyfikowań jednostek badania, na których podstawie przyjęto weryfikowany wynik, jest właściwa. [...] Gdyby się natomiast okazało, że korelacja taka nie wystąpiła, wówczas znaczna część zaklasyfikowań jednostek ze względu na jedną lub obydwie skorelowane cechy jest błędna" (Lutyński 1994: 227). Dodatkowym czynnikiem wpływającym na sensowność podejmowania tego typu weryfikacji jest siła korelacji między zmiennymi - jeśli jest bardzo znaczna, weryfikacja jest zasadna.

13 Osoby zainteresowane bardziej szczegółowym omówieniem tych błędów oraz przykładami prezentującymi różne przypadki stosunków rozmiarów poszczególnych błędów między sobą odsyłamy do tekstu źródłowego Jana Lutyńskiego (1994: 222-225). 
Analizy weryfikacyjne oparte na porównaniu wyników niepewnych dzielą się na kilka podtypów, do których można zaliczyć:

1. Zbieranie tych samych informacji dwoma sposobami, przy czym każdy sposób - zdaniem badacza - jest niepewny, np. gdy zadajemy te same pytania dotyczące wychowania dzieci obojgu rodzicom w dwóch osobnych wywiadach.

2. Zbieranie tych samych informacji za pomocą dwóch niepewnych technik w dwóch porównywalnych zbiorowościach z założeniem, że dla każdej ze zbiorowości stosuje się tylko jedną technikę lub odmianę danej techniki (inne wersje tego samego kwestionariusza). Tego typu badania często prowadzi się w ramach eksperymentów metodologicznych, gdy sprawdza się np. dwie wersje pytania celem wykrycia efektów pierwszeństwa, świeżości itp. (zob. Krzewińska 2006; Sułek 2001; Schwarz i in. 1989).

3. Badacz zbiera informacje od tej samej grupy respondentów, wykorzystując do tego dwie różne techniki jednocześnie, przyjmując, że jedna z nich jest bardziej wiarygodna. W badaniach dotyczących religijności informacje uzyskuje się za pomocą wywiadów kwestionariuszowych i wywiadów swobodnych, ale przyjmuje się, że wywiad swobodny dostarcza bardziej pewnych danych o badanym i dlatego traktuje się go jako technikę pewniejszą.

4. Bada się dwie zbiorowości (odpowiednio dobrane, a przez to porównywalne) za pomocą dwóch różnych technik, przyjmując (bądź sprawdzając to po zakończeniu badań), że wynikom otrzymanym za pomocą jednej z tych technik można ufać w większym stopniu, a więc traktować je jako bardziej pewne. Z tego typu badaniami można mieć do czynienia w przypadku studiów metodologicznych, kiedy porównuje się dwie techniki (lub więcej) poprzez zestawianie uzyskanych za ich pomocą wyników ${ }^{14}$.

Zastosowanie którejkolwiek z tych czterech odmian analiz weryfikacyjnych opartych na porównaniu wyników niepewnych pozwala na obliczenie różnic w pomiarach za pomocą dwóch technik. Przyjmuje się, że jeśli różnice nie pojawiły się, to obydwa sposoby zbierania informacji są wolne od błędów, a jeśli różnice wystąpiły - jeden z wyników jest obciążony błędem. Wielkości możliwych błędów oraz sposoby ich interpretacji dokładniej opisuje J. Lutyński w artykule poświęconym procedurom weryfikacyjnym (1994: 232-235).

Należy jeszcze krótko opisać technikę pogłębionego wywiadu weryfikacyjnego, która została opracowana na użytek weryfikacji zewnętrznej. Był on stosowany zarówno w przypadku pytań o opinię, jak i pytań o fakty, a jego zasadniczym celem było uzyskanie ponownej odpowiedzi respondenta na pytanie, które wcześniej już mu zadano i na które już raz odpowiadał. W trakcie takiego wywiadu ankieter

14 Takie porównanie technik (CAPI oraz trzech odmian ankiety CAWI - z logo, ze zdjęciem ankietera, z nagranym filmem, w którym ankieter czyta pytania z kwestionariusza) zaplanowano w projekcie realizowanym ze środków NCN: Wpływ zabiegów humanizowania procedury badawczej w ankiecie internetowej CAWI na wartość uzyskiwanych danych; umowa nr UMO-2014/15/B/HS6/01386, którego kierownikiem jest Katarzyna Grzeszkiewicz-Radulska. 
niejako ułatwiał respondentowi poprawne wykonanie stawianego przed nim zadania, czyli udzielenie odpowiedzi na pytanie zgodnie z normatywnym modelem (poprawnego) udzielania odpowiedzi, co często było jednoznaczne z rozłożeniem „pytania na elementy prostsze” (Koniarek 1975: 527). Dlatego też ankieter mógł wyjaśnić terminy, które zostały użyte w pytaniu, opowiedzieć, co respondent ma dokładnie zrobić (np. przypomnieć sobie, porównać), by nie tylko udzielił odpowiedzi, lecz także, by była ona przemyślana.

Kończąc charakterystykę trzech typów analiz weryfikacyjnych, trzeba zadać pytanie: czy wszystkie należy rozwijać, czy skupiać się tylko na tych, które pozwalają na liczbowe określenie występowania błędów, w dodatku z dużą pewnością? Otóż, jak pisze J. Lutyński, skupianie wysiłków tylko na analizach weryfikacyjnych z zastosowaniem pewnego sposobu otrzymywania danych doprowadziłoby do braku rozwoju $\mathrm{w}$ tej dziedzinie, ponieważ: $\mathrm{w}$ wielu sytuacjach (np. w przypadku przeżyć psychicznych) nie można uzyskać pewnych danych, nawet, gdy podejmie się dość duży wysiłek. Odwoływanie się do informacji pochodzących z innych źródeł zawsze jest związane z podjęciem dodatkowych badań, czasami bardzo kosztownych (w przypadku analiz weryfikacyjnych opartych na korelacjach zmienne pochodzą $\mathrm{z}$ tego samego badania). Sposoby weryfikacji zewnętrznej, wykorzystujące porównywanie wyników niepewnych, dają możliwość wykrycia innych źródeł błędów, które są interesujące ze względu na inne metodologiczne cele, np. badanie efektu ankieterskiego, badanie efektów związanych z konstrukcją kwestionariusza, czy wreszcie porównania technik.

\subsubsection{Weryfikacja wewnętrzna - procedury, metody, ograniczenia}

Omawianie weryfikacji wewnętrznej trzeba zacząć od opisu stworzonej przez J. Lutyńskiego koncepcji pytania kwestionariuszowego jako narzędzia badawczego, w której podstawę do wyróżnienia czterech koncepcji: testowej, wskaźnikowej, tradycyjnej informacyjnej i rozszerzonej informacyjnej koncepcji pytania, było kilka kryteriów (zamieszczonych w tabeli 6).

Zatrzymajmy się jeszcze przez chwilę na rozszerzonej informacyjnej koncepcji pytania kwestionariuszowego jako narzędzia badawczego i prześledźmy proces przechodzenia od pytania zadanego respondentowi do uzyskania informacji o badanym zjawisku (proces ten został bardzo skrótowo przedstawiony w tabeli 6). Jan Lutyński sformułował kilka założeń, które powinny zostać spełnione, by można było orzekać o badanych zjawiskach na podstawie deklaracji respondentów. Założenia te mogą mieć postać definicji lub twierdzeń empirycznych składających się na model pytania jako narzędzia badawczego ${ }^{15} \mathrm{i}$ dotyczą one:

15 Jan Lutyński proponował, by badacze budowali takie modele dla każdego pytania w kwestionariuszu, a jeśli nie potrafią tego zrobić, to może być sygnał, że pytanie nie jest dobrym narzędziem. 
- [...] przebiegu procesu komunikowania (np. że pytanie przeczytano właściwie respondentowi, że dokładnie zanotowano jego odpowiedź, że była to odpowiedź respondenta, a nie członka jego rodziny, że odpowiedź ta została poprawnie zaklasyfikowana przez kodera);

- procesów psychicznych respondenta, np. że respondent zrozumiał pytanie zgodnie $z$ intencją badacza, dokonał wszystkich zabiegów wymagających sformułowania stanowiska (takich, jak przypomnienie sobie, wyobrażenie, uogólnienie, syntetyzowanie) i stanowisko to zgodnie z prawdą zwerbalizował;

- stosunku sytuacji problemowej wywołanej przez pytanie do sytuacji występujących poza wywiadem, w życiu respondenta - chodzi o to, czy respondent odpowiadając na pytanie w kwestionariuszu przedstawia nam trwałą opinię reprezentatywną dla sytuacji spoza wywiadu;

- rzeczywistych prawidłowości czy związków występujących pomiędzy zjawiskami interesującymi badacza (Kubiak, Przybyłowska 1999: 105-106).

Tabela 6. Koncepcje pytania kwestionariuszowego jako narzędzia badawczego oraz kryteria służące do rozróżnienia tych koncepcji

\begin{tabular}{|c|c|c|c|c|}
\hline \multirow{2}{*}{$\begin{array}{l}\text { Kryteria służą- } \\
\text { ce do odróżnie- } \\
\text { nia koncepcji }\end{array}$} & \multicolumn{4}{|c|}{ Koncepcja pytania jako narzędzia badawczego } \\
\hline & testowa & wskaźnikowa & $\begin{array}{c}\text { tradycyjna } \\
\text { informacyjna }\end{array}$ & $\begin{array}{l}\text { rozszerzona } \\
\text { informacyjna }\end{array}$ \\
\hline 1 & 2 & 3 & 4 & 5 \\
\hline $\begin{array}{l}\text { Pytanie jest żą- } \\
\text { daniem informa- } \\
\text { cji o badanym } \\
\text { zjawisku }\end{array}$ & $\begin{array}{l}\text { Pojedyncze } \\
\text { pytanie nie } \\
\text { jest żądaniem } \\
\text { informacji o ba- } \\
\text { danym zjawisku, } \\
\text { o którym ma } \\
\text { świadczyć łącz- } \\
\text { na odpowiedź } \\
\text { na wszystkie } \\
\text { pytania w teście }\end{array}$ & $\begin{array}{l}\text { Odpowiedź na } \\
\text { pytanie dostar- } \\
\text { cza informacji } \\
\text { o wskaźniku, } \\
\text { a nie o indica- } \\
\text { tum, które jest } \\
\text { badanym zjawi- } \\
\text { skiem. }\end{array}$ & $\begin{array}{l}\text { Pytanie jest } \\
\text { żądaniem } \\
\text { semantycznej } \\
\text { (dającej się } \\
\text { ocenić w kate- } \\
\text { goriach prawda/ } \\
\text { fałsz) informacji } \\
\text { o badanym } \\
\text { zjawisku }\end{array}$ & $\begin{array}{l}\text { Pytanie nie musi } \\
\text { żądać wprost } \\
\text { informacji o ba- } \\
\text { danym zjawisku }\end{array}$ \\
\hline $\begin{array}{l}\text { Określenie } \\
\text { informacji przed } \\
\text { przystąpieniem } \\
\text { do badania }\end{array}$ & $\begin{array}{l}\text { Poszukiwana in- } \\
\text { formacja znana } \\
\text { przed sformuło- } \\
\text { waniem pytania }\end{array}$ & $\begin{array}{l}\text { Powinno być } \\
\text { zdefiniowane } \\
\text { indicatum przed } \\
\text { przystąpieniem } \\
\text { do badania (po- } \\
\text { stulatywne) }\end{array}$ & $\begin{array}{l}\text { Informacja jest } \\
\text { sprecyzowana } \\
\text { przed przystą- } \\
\text { pieniem do ba- } \\
\text { dania }\end{array}$ & $\begin{array}{l}\text { Zjawisko musi } \\
\text { być określone } \\
\text { przed rozpoczę- } \\
\text { ciem badań }\end{array}$ \\
\hline $\begin{array}{l}\text { Pytanie pełni sa- } \\
\text { modzielną rolę } \\
\text { versus pytanie } \\
\text { jest elementem } \\
\text { baterii pytań }\end{array}$ & $\begin{array}{l}\text { Pytanie jako } \\
\text { item w teście }\end{array}$ & $\begin{array}{l}\text { Często do okre- } \\
\text { ślenia jednego } \\
\text { indicatum bierze } \\
\text { się pod uwagę } \\
\text { wiele wskaźni- } \\
\text { ków (baterię) }\end{array}$ & $\begin{array}{l}\text { Każde pytanie } \\
\text { jest samodzielne } \\
\text { w kwestiona- } \\
\text { riuszu }\end{array}$ & $\begin{array}{l}\text { Pytanie ma } \\
\text { bardzo złożoną } \\
\text { strukturę, na któ- } \\
\text { rą składają się } \\
\text { pytania: w kwe- } \\
\text { stionariuszu, } \\
\text { pytanie kodera } \\
\text { i jednostkowe } \\
\text { pytanie badacza }\end{array}$ \\
\hline
\end{tabular}


Tabela 6 (cd.)

\begin{tabular}{|c|c|c|c|c|}
\hline 1 & 2 & 3 & 4 & 5 \\
\hline $\begin{array}{l}\text { Założenie przyj- } \\
\text { mowanie przy } \\
\text { przechodzeniu } \\
\text { od odpowiedzi } \\
\text { respondenta } \\
\text { do sformułowa- } \\
\text { nia sądu o bada- } \\
\text { nym zjawisku }\end{array}$ & $\begin{array}{l}\text { Przejście } \\
\text { od odpowiedzi } \\
\text { na poszczególne } \\
\text { itemy do przypi- } \\
\text { sania badanemu } \\
\text { jakiejś wartości } \\
\text { odpowiadającej } \\
\text { badanej cesze } \\
\text { opiera się na } \\
\text { założeniu, że ten } \\
\text { zbiór itemów } \\
\text { jest testem rze- } \\
\text { telnym i trafnym }\end{array}$ & $\begin{array}{l}\text { Przejście od od- } \\
\text { powiedzi na } \\
\text { pytania do wnio- } \\
\text { skowania } \\
\text { o wystąpieniu } \\
\text { indicatum opiera } \\
\text { się na założeniu, } \\
\text { że wskaźniki } \\
\text { są właściwie } \\
\text { dobrane i na } \\
\text { podstawie ich } \\
\text { wystąpienia } \\
\text { można mówić } \\
\text { o wystąpieniu } \\
\text { (nigdy ze 100\% } \\
\text { pewnością) } \\
\text { indicatum }\end{array}$ & $\begin{array}{l}\text { Przejście pomię- } \\
\text { dzy odpowiedzią } \\
\text { badanego a są- } \\
\text { dem o zjawisku } \\
\text { jest bardzo pro- } \\
\text { ste, gdyż infor- } \\
\text { macja dotycząca } \\
\text { badanego jest } \\
\text { prawie tożsama } \\
\text { z informacją } \\
\text { o badanym } \\
\text { zjawisku }\end{array}$ & $\begin{array}{l}\text { Przy prze- } \\
\text { chodzeniu } \\
\text { od odpowiedzi } \\
\text { udzielonej przez } \\
\text { respondenta } \\
\text { do odpowiedzi } \\
\text { na jednostkowe } \\
\text { pytanie badacza } \\
\text { musi wystąpić } \\
\text { wiele założeń }\end{array}$ \\
\hline $\begin{array}{l}\text { Istnienie możli- } \\
\text { wości empirycz- } \\
\text { nej weryfikacji } \\
\text { założeń przyj- } \\
\text { mowanych przy } \\
\text { przechodzeniu } \\
\text { od odpowiedzi } \\
\text { respondenta } \\
\text { do sformułowa- } \\
\text { nia sądu o bada- } \\
\text { nym zjawisku }\end{array}$ & $\begin{array}{l}\text { Istnieją procedu- } \\
\text { ry pozwalające } \\
\text { określić trafność } \\
\text { i rzetelność testu }\end{array}$ & $\begin{array}{l}\text { Bardzo często } \\
\text { brak dobrego } \\
\text { zdefiniowania } \\
\text { indicatum przed } \\
\text { przystąpieniem } \\
\text { do badania } \\
\text { powoduje, } \\
\text { że w analizie } \\
\text { korelacyjnej } \\
\text { prowadzonej } \\
\text { ex post ustala } \\
\text { się wystąpienie } \\
\text { indicatum }\end{array}$ & $\begin{array}{l}\text { Nie ma możliwo- } \\
\text { ści oszacowania } \\
\text { błędu popeł- } \\
\text { nianego przy } \\
\text { przechodzeniu } \\
\text { z informacji } \\
\text { jednostkowej na } \\
\text { informacje o ba- } \\
\text { danym zjawisku. } \\
\text { Można liczyć } \\
\text { błąd dla całego } \\
\text { wywiadu, a nie } \\
\text { dla pojedyncze- } \\
\text { go pytania }\end{array}$ & $\begin{array}{l}\text { Przy przyjściu } \\
\text { pomiędzy } \\
\text { tymi dwoma } \\
\text { odpowiedziami } \\
\text { popełnia się } \\
\text { minimalny błąd, } \\
\text { który można } \\
\text { pominąć w tym } \\
\text { rozumowaniu }\end{array}$ \\
\hline
\end{tabular}

Źródło: opracowanie własne na podstawie tekstów: Lutyński (1970) i Kubiak, Przybyłowska (1999).

W rozszerzonej informacyjnej koncepcji pytania kwestionariuszowego jako narzędzia badawczego znalazło się również miejsce na weryfikację, która powinna być prowadzona przed przystąpieniem do fazy terenowej badań. Można zastosować weryfikację zewnętrzną ma podstawie dokumentów, obserwację oraz procedurę weryfikacji wewnętrznej (np. wywiad o wywiadzie). Zanim przejdziemy do omówienia tej metody, czytelnikowi należy się jeszcze kilka wyjaśnień dotyczących samej weryfikacji wewnętrznej.

Aby liczbowo wyrazić ocenę wyniku badań, w których zastosowano wywiad kwestionariuszowy stanowiący efekt weryfikacji wewnętrznej, należy zbudować model prawidłowego przebiegu procesu otrzymywania informacji. J. Lutyński opracował metodę konstruowania takiego modelu, którą oparł na procedurze 
wnioskowania o indicatum na podstawie wskaźników (Mokrzycki 1971: 71-72). Model formowania się jednostkowej informacji za każdym razem miał być konstruowany dla pojedynczego pytania kwestionariuszowego i uwzględniał cały proces badawczy od chwili sformułowania przez badacza pytania z kwestionariusza do stwierdzenia, że w przypadku danego badanego wystąpił określony stan rzeczy. Pierwszym etapem prac było wymienienie kolejnych etapów procesu otrzymywania informacji. Etapy te rozpisywano, uwzględniając przekazy między osobami: badacza - ankietera - respondenta - kodera, co wyglądało w następujący sposób:

[...] I. pytanie sformułowane przez badacza jako pytanie kwestionariuszowe, II. pytanie wydrukowane (napisane) w tekście kwestionariusza, III. pytanie zadane respondentowi. IV. odpowiedź (reakcja słowna lub milczenie) respondenta, V. zapis odpowiedzi respondenta, VI. symbol klasyfikacyjny kodera wraz z interpretacją. Ostatni, VII przekaz stanowi otrzymana informacja (Lutyński 1994: 248).

Następnym krokiem było sformułowanie twierdzeń odnoszących się do poszczególnych, przebiegających w prawidłowy sposób etapów procesu uzyskiwania odpowiedzi na pytanie z kwestionariusza. Twierdzenia te dotyczyły m.in.: identyczności pytania z kwestionariusza i pytania sformułowanego przez badacza, równoważności pytania zadanego przez ankietera i pytania zawartego w kwestionariuszu, autentyczności zapisu odpowiedzi udzielonej przez respondenta na zadane pytanie, prawidłowości zapisu odpowiedzi, poprawności klasyfikacji odpowiedzi, którą posługuje się koder, poprawności procedury zaklasyfikowania odpowiedzi przez kodera. Na na tym nie kończy się budowa takiego modelu, bowiem należy jeszcze uwzględnić inne elementy wchodzące w skład procesu, np. respondenta i jego wewnętrzne reakcje pojawiające się w związku z zadaniem mu pytania. Szczegółową analizę reakcji badanego na zadanie mu pytania i związane $\mathrm{z}$ tym udzielanie odpowiedzi na pytania kwestionariuszowe opisała B. Tuchańska (1975), wyróżniając kilka etapów. Respondent musi usłyszeć całe pytanie, które powinno dotrzeć do jego świadomości, następnie powinien je zrozumieć i zaakceptować, czyli uznać zawarte w pytaniu założenia (empiryczne - odnoszące się do badanej rzeczywistości, pragmatyczne - powiązane z osobą respondenta, logiczne - związane z procesem rozumienia pytania). Następnie badany powinien zająć się formowaniem swojego stanowiska i zwerbalizowaniem odpowiedzi. Na każdym etapie tego modelu mogą wystąpić pewne zakłócenia czy nieprawidłowości, które spowodują, że respondent albo nie odpowie, albo udzieli odpowiedzi nieistotnej ${ }^{16}$ lub nietrafnej ${ }^{17}$. Lista tych zakłóceń jest dość długa, dlatego wymieniamy tylko kilka najbardziej typowych: odbiór pyta-

16 Odpowiedź istotna to przynosząca poszukiwaną informację, a więc nieistotna to taka, która tej poszukiwanej informacji nie przynosi.

17 Odpowiedź nietrafna to taka, która nie przynosi prawdziwej poszukiwanej informacji w przeciwieństwie do trafnej, która daje prawdziwą poszukiwaną informację. 
nia może być zakłócony, respondent może nie zrozumieć niektórych słów, całego pytania lub też operacji myślowej, którą ma wykonać (np. przypomnienie sobie czegoś, porównanie dwóch sytuacji itp.), w przygotowanych odpowiedziach nie ma takiej, która odpowiada sytuacji badanego, pojawiły się niekorzystne emocje spowodowane drażliwością pytania itp.

Normatywny model formowania się jednostkowej informacji, obok elementów odnoszących się do respondenta i jego reakcji na pytanie, został uzupełniony o elementy związane ze stosunkiem pomiędzy sytuacją wywiadu a sytuacjami innymi (niepowiązanymi z wywiadem, do których jednak odnosi się poszukiwana informacja ${ }^{18}$ oraz o charakterystyki opisujące prawidłowości zjawisk poza wywia$\operatorname{dem}^{19}$. Niezmiernie istotny jest fakt, że model udzielania odpowiedzi na pytanie z kwestionariusza nie jest identyczny w stosunku do każdego pytania. Metodolog określając to, w jaki sposób udzielano odpowiedzi na dane pytanie, za każdym razem buduje taki model od początku. Wybiera te elementy, które wystąpiły w konkretnej sytuacji (np. nie uwzględni w analizie twierdzeń dotyczących zakłóceń wpływających na zrozumienie pytania, jeśli proces tego rozumienia przebiegał bez żadnych problemów).

Pozostaje jeszcze odpowiedzieć na pytanie, skąd wziąć informacje dotyczące poszczególnych elementów składających się na ten model. Twierdzenia dotyczące pewnych prawidłowości występowania zjawisk poza wywiadem powinny być uzasadnione wcześniej, najlepiej na podstawie danych empirycznych (np. pochodzących z innych badań). Informacje na temat podobieństwa między sytuacją wywiadu a sytuacjami pozabadawczymi - kiedy badany dzieli się swoimi poglądami, opiniami, opowiada o swoich zachowaniach - powinny pochodzić z dodatkowych informacji od ankieterów (ankiety do ankieterów, uwagi do wywiadów, adnotacje w trakcie wywiadów) oraz nagranego wywiadu. Dane na temat sposobu klasyfikowania odpowiedzi respondenta można pozyskać, analizując dokumenty związane $\mathrm{z}$ instrukcją do wywiadu i wstępnym opracowaniem materiałów, natomiast dane na temat pracy kodera - dokonując kontroli logicznej przygotowanej bazy danych. Zdobycie wszystkich tych informacji jest czasochłonne, ale możliwe do przeprowadzenia. Najwięcej trudności sprawia dotarcie do wewnętrznych reakcji respondenta i jego procesów psychicznych. Tutaj z pomocą przychodzi zastosowanie techniki weryfikacyjnej nazwanej wywiadem o wywiadzie, która ma na celu odtworzenie sposobu, $\mathrm{w}$ jaki badany odpowiadał na pytania $\mathrm{w}$ trakcie wywiadu kwestionariuszowego.

18 Wskazany element jest związany z tym, na ile odpowiedzi respondenta są spójne z poglądami, jakie posiada badany w danej kwestii. Inaczej mówiąc, czy zaprezentował on swoją prawdziwą opinię i identycznie odpowiedziałby na podobne pytanie - w innej niż wywiad - sytuacji, czy też podzielit się opinią oficjalną, a może skonstruowaną „na poczekaniu” na potrzeby rozmowy z ankieterem.

19 Odnosi się to do sytuacji, w której przyjęte przez badacza miary rzeczywiście odzwierciedlają badane zjawisko, np. na ile czas poświęcony na czytanie w gazecie działu dotyczącego spraw politycznych może świadczyć o stopniu zainteresowania polityką (Lutyński 1994: 256). 
Ilona Przybyłowska tak charakteryzuje tę technikę:

(w)ywiadem o wywiadzie nazwaliśmy rozmowę z respondentem na temat przebiegu reakcji wewnętrznej respondenta na pytanie kwestionariusza. Jej celem było uzyskanie danych umożliwiających: - ocenę wartości istotnej odpowiedzi respondenta na pytanie kwestionariusza w kategoriach: prawidłowa, a więc trafna, nietrafna względnie trafna przypadkowo;

- ustalenie nieistotności odpowiedzi respondenta na pytanie zadane w wywiadzie zasadniczym (Przybyłowska 1975: 457).

Wywiad o wywiadzie był klasyfikowany jako wywiad swobodny, ze standaryzowaną listą poszukiwanych informacji (z modyfikacją polegającą na przygotowaniu wzorów pytań do badanych), co oznacza, że na poziomie zbierania materiałów jest techniką o niskim stopniu standaryzacji, ale na poziomie ich opracowania charakteryzuje się wysokim poziomem standaryzacji, ponieważ jego wyniki są opracowywane ilościowo (Przybyłowska 1978). Do realizacji takiego wywiadu potrzebne są: zamknięta lista jednostkowych pytań badacza, karty pytań, schematy toku wywiadu (w postaci graficznej) oraz wspomniane już wzory pytań do respondentów ${ }^{20}$. Po przeprowadzeniu tych wywiadów uzyskane informacje były zestawiane $\mathrm{z}$ modelem udzielania odpowiedzi na pytanie i na tej podstawie orzekano, czy respondent reagował w sposób prawidłowy, czy nieprawidłowy. A. Kubiak oceniła stosowanie wywiadu o wywiadzie jako bardzo owocne, gdyż „[...] dostarczył wielu opisowych informacji o sposobach rozumienia pytań przez respondentów i sposobach formowania przez nich odpowiedzi" (Kubiak 2008: 16).

J. Lutyński zauważał ograniczenia i problemy, towarzyszące stosowaniu metod weryfikacji wewnętrznej. W zakończeniu swojego artykułu pisał m.in. o trudnościach stosowania tej procedury w przypadkach, gdy jedną informację uzyskuje się za pomocą kilku pytań problemach i osiąga się wystarczająco pewne dane potwierdzające prawidłowy przebieg wewnętrznej reakcji respondenta $\mathrm{w}$ trakcie udzielania odpowiedzi na pytanie kwestionariuszowe. Zwracał uwagę na niemożność zastosowania tej procedury w badaniach masowych i ograniczanie jej aplikacji tylko do specjalnych metodologicznych prób empirycznych, w odniesieniu do kilku zaledwie pytań. Widział jednak potrzebę jej wykorzystania i stosowania kilku procedur weryfikacyjnych w trakcie jednego badania.

20 Osoby zainteresowane szczegółami dotyczącymi zarówno fazy przygotowania, realizacji tych wywiadów, jak i ich oceną metodologiczną należy odesłać do tekstu artykułu llony Przybytowskiej (1975). 


\subsection{Analizy weryfikacyjne $z$ dzisiejszej perspektywy - ocena współpracowników i uczniów Jana Lutyńskiego}

Zanim oddamy głos współpracownikom i uczniom Jana Lutyńskiego, którzy ocenią koncepcję analizy weryfikacyjnej z dzisiejszej perspektywy, sprawdzimy, co napisał o niej sam jej twórca w krótkim podsumowaniu dotyczącym badań weryfikacyjnych, opublikowanym w 1990 r., już po jego śmierci (Lutyński 1990). Wskazał tam trzy ważne elementy:

1. Pracochłonność, trudność prowadzenia, tylko częściowa skuteczność wypracowanych i stosowanych metod weryfikacyjnych. Ta ostatnia uwaga odnosiła się przede wszystkim do wywiadu o wywiadzie i pogłębionego wywiadu weryfikacyjnego. Zdaniem Lutyńskiego, wymagały one dokładniejszego i lepszego przygotowania w celu uzyskania potwierdzenia teoretycznego dla wypracowanego modelu.

2. Owocność wywiadów o wywiadzie i wywiadów pogłębionych, gdyż korelują one z wynikami testów psychologicznych (wywiad o wywiadzie) i weryfikacją zewnętrzną za pomocą danych zawartych w dokumentach (wywiad pogłębiony). Dodatkowo wywiad o wywiadzie pozwolił na uzyskanie informacji na temat rozumienia przez respondenta poszczególnych pytań kwestionariusza, co zaowocowało skonstruowaniem skali do określania trudności pytań. Po dołączeniu do niego informacji zaczerpniętych $\mathrm{z}$ innych metod wykorzystano go do wskazania źródeł braków informacji i udzielania nieistotnych odpowiedzi. Cennym odkryciem było również to, „[...] jaki udział w niepowodzeniach w stosowaniu pytań i pojawianiu się błędów informacji mają ankieterzy i różnorodne błędy w ich postępowaniu. Ten udział jest duży. Wyniki badań wskazują więc na potrzebę dokładniejszego ich szkolenia i określają ich kierunki” (Lutyński 1990: 37).

3. Możliwość dokładniejszego niż przedtem określenia wartości pytań, będących narzędziami otrzymywania informacji. Uwaga ta odnosi się szczególnie do pytań o opinie, w stosunku do których nie można było stosować weryfikacji zewnętrznej.

Jak widać, ocena koncepcji analiz weryfikacyjnych nie jestem jednoznaczna nawet dla jej autora. Zaproponowane przez niego procedury weryfikacji zewnętrznej i wewnętrznej, pomimo dużych nakładów pracy i czasu, nie przyniosły spodziewanych rezultatów, czyli nie pozwoliły na wypracowanie dającej się stosować (realizowalnej) metody weryfikacji.

W trakcie wywiadów swobodnych, prowadzonych ze współpracownikami i uczniami ${ }^{21}$ profesorów Gostkowskiego i Lutyńskiego, którym zadano pytania

21 Wywiadów udzielili: Krystyna Lutyńska (KL), Kazimierz Maciej Słomczyński (KMS), Andrzej Paweł Wejland (APW), Anna Kubiak (AK), Ilona Przybyłowska (IP), Paweł Daniłowicz (PD), 
o ocenę analiz weryfikacyjnych z dzisiejszej perspektywy oraz możliwość powtórzenia, kontynuowania tych analiz obecnie, uzyskano opinie zbieżne ze sformułowanymi przez J. Lutyńskiego. Warto wymienić kilka wątków, które pojawiły się w refleksjach zapytanych osób:

1. Ogrom pracy, która była związana z prowadzeniem tych badań i możliwościami realizacyjnymi tego typu badań obecnie.

2. Elementy więziotwórcze i wspólnotowe dla łódzkiej szkoły naukowej.

3. Wysoki stopień trudności zadań stawianych przed badanymi i nadmierne zaangażowanie ich w proces zbierania materiałów.

4. Błędy występujące w założeniach i dotyczące elementów składowych tej koncepcji.

5. Perspektywy paradygmatyczne prowadzenia takich badań.

Pierwszy element, na który wskazywali wszyscy nasi rozmówcy, to ogrom pracy podczas realizacji badań, będących podstawą do analiz weryfikacyjnych, niezmiernie wydłużający poszczególne etapy postępowania badawczego. W każdym z badań (zarówno tych we Włocławku, jak i tych w Łodzi) poświęcano mnóstwo czasu na przygotowywanie modeli poszczególnych pytań, zbieranie materiałów podstawowych (prowadzenie wywiadów kwestionariuszowych) i dodatkowych, potrzebnych do analiz weryfikacyjnych (prowadzenie wywiadów pogłębionych, wywiadów o wywiadach, docieranie do danych zapisanych w dokumentach), a następnie na spisywanie i analizowanie tych materiałów.

[...] to wymagało niezwykłego trudu. To wymagało pracy całego zespołu przez całe lata. Wszyscy byli zaangażowani na całe dni roboty, nie na chwilę. Ogromna praca. (APW)

Tak, jak zostały wymyślone metody weryfikacji, to one sa bardzo trudne do zrealizowania i sa to bardzo kosztowne badania, [...] i sa bardzo czasochtonne. (IP)

Każdy respondent miał taka teczkę, a my potem na piechotę przepisywaliśmy i kodowaliśmy. To wszystko było dramatyczne. Bardzo obciązajace wyzwanie. (AK)

Zdaniem rozmówców, powtórzenie tych badań dziś byłoby właściwie niemożliwe. Ze względu na czasochłonność, inny sposób organizacji nauki (system finansowania badań, czas trwania projektów badawczych, tworzenie tymczasowych zespołów badawczych, angażowanie się w kilka projektów jednocześnie), kosztowność tych badań, inny stosunek do badań społecznych (inaczej postrzegano badania społeczne, chętniej brano w nich udział) oraz inne podejście badaczy do danego problemu badawczego (ówczesne pełne zaangażowanie w projekt, wiarę w pomysł oceniono jako niemożliwe do powtórzenia).

Wszyscy weszli w ten program Lutyńskiego z petnym przekonaniem. Mogli sobie ponarzekać, że to strasznie ciężkie, trudne, ale była jakaś perspektywa. (APW)

Andrzej Rostocki (AR) i Franciszek Sztabiński (FSz). W nawiasach umieszczono inicjały, które zostały użyte w dalszej części tego rozdziału do oznaczenia osób, których wypowiedzi cytujemy. 
System grantowy, który narzuca reżim badawczy, komercjalizacja badań nie pozwala na takie badania. To jest taki metodologiczny eksces, kiedy ta refleksja metodologiczna ma być równoległa, a nawet ma wyprzedzać myślenie badacza o calym projekcie i ma być wmontowana w cała procedurę badawczą. Badania miały wtedy odświętny charakter, było ich kilka w roku i nie funkcjonowały w takim otoczeniu. Można było wypracować zupetnie inny styl pracy z ankieterami, inne budowanie wejścia czy aranżacji wywiadu. (AK)

Ta praca i godziny spędzane przy projektowaniu, realizacji i opracowaniu wyników badań miały tę dobrą stronę, że budowały relacje w grupie badaczy. Właściwie we wszystkich wywiadach prowadzonych z osobami pracującymi przy projekcie dotyczącym analiz weryfikacyjnych mówiono o tym, że cały czas dyskutowano o założeniach projektu, spędzano długie godziny na wypracowywaniu pomysłów i krytycznej ich analizie. Te wszystkie naukowe działania nie byłyby możliwe, gdyby między członkami zespołu badawczego nie istniały przyjacielskie relacje. W wywiadach mówiono bardzo dużo właśnie o tych kontaktach, koleżeńskich i ciepłych relacjach oraz o atmosferze tworzonej przez J. Lutyńskiego.

Myśmy ze sobą godzinami rozmawiali. (AK)

Wielokrotnie zwracano uwagę na nadmierne zaangażowanie osób badanych i obciążanie ich zadaniami, którym wielokrotnie nie były w stanie sprostać. Przypomnijmy tylko, że w pełnym programie analiz weryfikacyjnych, obejmujących wszystkie elementy weryfikacji wewnętrznej i zewnętrznej, od każdego respondenta oczekiwano: udzielenia odpowiedzi na pytania w wywiadzie kwestionariuszowym, wzięcia udziału w pogłębionym wywiadzie weryfikacyjnym, w trakcie którego ankieter przedstawiał elementy składające się na proces poprawnego udzielania odpowiedzi (np. wyjaśniał terminy, udzielał wskazówek, co respondent powinien zrobić), odpowiedzenia na pytania w wywiadzie o wywiadzie dotyczącym próby rekonstrukcji sposobu odpowiadania na pytanie (badany opowiadał, co się z nim „działo”, gdy zadawano mu pytania z kwestionariusza i co po kolei robił, by na nie odpowiedzieć), rozwiązywał również test słownikowy po to, by sprawdzić rozumienie terminów użytych w pytaniach, wypełniał też testy psychologiczne. Zdaniem jednego z rozmówców, również badani nie do końca byli chyba świadomi tego, co ich czeka (choć nie można tu mówić o nieetyczności: badani dobrowolnie godzili się na udział w tym metodologicznym przedsięwzięciu i mogli w każdej chwili z niego zrezygnować). Również z powodu stopnia zaangażowania badanych trudno sobie wyobrazić powtórzenie tego typu badań dzisiaj.

Teraz badania robi się trudniej, więc i te badania z tego punktu widzenia byłyby trudniejsze. Gdzie znajdziesz ochotników na takie pogłębione rozmowy? (APW)

Ja bym to zrobił teraz inaczej, tak bym nie męczył człowieka. (PD)

To budziło mój opór. My chcemy wypracować pewne reguły, a my tych respondentów „katowaliśmy”. Bo to był wywiad, wywiad o wywiadzie, byty testy. (AK) 
Najwięcej krytycznych wypowiedzi dotyczyło elementów składających się na koncepcję analiz weryfikacyjnych w kontekście perspektyw paradygmatycznych. Podważano sensowność prowadzenia dzisiaj tego typu analiz w świetle aktualnych nastawień teoretycznych i przyjmowanych paradygmatów. Niewątpliwe koncepcja wypracowana przez J. Lutyńskiego mieściła się w paradygmacie normatywnym, dominującym w socjologii w początkowym okresie istnienia i pracy łódzkiej szkoły metodologicznej. Dziś, gdy do głosu doszedł też paradygmat interpretatywny, znacznie bardziej popularny od normatywnego, zakładanie istnienia jakiejś zewnętrznej rzeczywistości, do której można dotrzeć za pomocą pytań zadawanych badanym wydaje się niemożliwe do zrealizowania.

Możliwe to one sa zawsze do przeprowadzenia. Tylko czy jest sens takie badania prowadzić... bo z punktu widzenia drugiego paradygmatu ja bym tych badań już nie robił. Ktoś może by mógł takie badania zrobić $w$ przekonaniu, że stary paradygmat działa, że powinien działać, weryfikacja jest rzecza potrzebna. (APW)

Oprócz tych fundamentalnych wątpliwości pojawiły się zastrzeżenia odnoszące się do konkretnych elementów analiz weryfikacyjnych oraz do prób uchwycenia całościowego sensu prowadzenia tego typu analiz. Mówiono zatem o tym, że skonstruowany model udzielania odpowiedzi w wywiadzie kwestionariuszowym uwzględniał zbyt wiele czynników, które nie dawały się potem badać i kontrolować. Podnoszono również sprawę bezsensowności pytania badanych po upływie jakiegoś czasu od badania o pewne elementy związane $z$ udzielaniem przez nich odpowiedzi na pytania. Wskazywano, że respondent rzadko kiedy uświadamiał je sobie. Podkreślano, że jakąś nadzieję wiązano z weryfikacją zewnętrzną, opartą na dokumentach, jednak koszty związane $\mathrm{z}$ dotarciem do tych danych były zbyt duże.

Tam założeń po drodze było zbyt dużo. Konstrukcja metodologiczna, która pokazywała słabość samej siebie, niepewność samej siebie. [...] Ten program był przeciążony intelektualnie, ta myśla o uporzadkowaniu logicznym, o wysterylizowaniu tego, a to jest bardziej zabrudzone, bardziej niejednoznaczne. (APW)

Osobiście nie jestem przekonany, żeby sens miała ta weryfikacja wewnętrzna w takim wywiadzie po wywiadzie, gdzie jest próba odtworzenia tego, co człowiek myślał odpowiadają na pytania. To ewentualnie miałoby sens to, co się często w wywiadach kognitywnych robi-głośne myślenie. (FSz) Myśmy myśleli, że uda się znaleźć jakieś związki między tymi wyrafinowanymi metodami a jakimiś bardziej prostymi i że w masowym stosowaniu, np. test rozumienia słów wystarczy za wywiad o wywiadzie. Ale tych zwiazków myśmy w tych badaniach nie złapali (może dlatego, że zbiorowości były zbyt małe). Nie było możliwości rozpętania tych badań na szersza skalę, bo już nie było środków i sił, żeby to wszystko zrobić. (IP)

Część dotycząca weryfikacji zewnętrznej wzbudziła zainteresowanie. IFiS PAN sfinansował badania na ten temat, które z P. Sztabińskim przeprowadziłem. Oni zgodzili się na całe badania, i żeby za to płacić, dotyczace faktów zewnętrznych tzw. mocnych zmiennych. Tamte pozostałe przestały ich interesować. (PD) 
Tam się próbowało czegoś w moim przekonaniu niemożliwego, mianowicie złapania oddziaływania bardzo wielu różnych zmiennych. Przecież te procedury byly takie quasi-eksperymentalne. Tu się coś włączało, tu się coś wyłączało, ale tak naprawdę to mieliśmy świadomość, że to jednocześnie oddziałuje te 1000 czynników i my nie jesteśmy w stanie tego kontrolować. (AK)

Przyglądając się wszystkim tym uwagom i refleksjom, należy zadać pytanie o jakąś globalną ocenę podejścia do weryfikacji, wypracowaną przez zespół kierowany przez J. Lutyńskiego. Bezwzględnie należy uznać za sukces badaczy należących do łódzkiej szkoły metodologicznej fakt, że zrealizowali oni duże badania, które pokazały ich sposób myślenia o badaniach socjologicznych. Dodatkowo uwrażliwiały ich na pewne istotne kwestie, dotyczące samego procesu badawczego, pozwoliły np. odpowiedzieć na pytania:

- Z jaką koncepcją pytania jako narzędzia badawczego ma do czynienia socjolog w konkretnym badaniu?

- Czy jest w stanie zbudować model udzielania odpowiedzi na dane pytanie?

- Na jakiej podstawie będzie w stanie przejść od odpowiedzi respondenta do stwierdzenia, że miały miejsce pewne fakty?

Dodatkowym atutem tych badań była ich atrakcyjność i to, że stanowiły intelektualne wyzwanie dla ich realizatorów.

Kiedy badacz tworzy narzędzia to odwołanie się do koncepcji pytań jako narzędzi badawczych Lutyńskiego jest jak najbardziej zdrowe i wskazane, ale same procedury weryfikacyjne wydaja mi się nierealistyczne. (AK)

Właściwie wskazówka, która płynęła z tych badań była taka, że trzeba taki model pytania spróbować, żeby sobie uświadomić, czego się wymaga od respondenta i na poziomie rozważań czysto teoretycznych można się zorientować, czy to jest sensowne, czy to nie sa zbyt duże wymagania. (IP)

Po zakończeniu badań weryfikacyjnych prowadzonych w Łodzi idea weryfikacji nie została już nigdy podjęta przez zespół Lutyńskiego. Napisano kilka opracowań na temat tego badania, ale nie miały one całościowego charakteru (jak piąty tom Analiz i prób technik badawczych w socjologii, poświęcony badaniom z Włocławka). Nikt inny nie posługiwał się tą metodą, prawdopodobnie ze względu na ponadprzeciętnie skomplikowaną procedurę i wielość wyzwań realizacyjnych. Nie oznacza to jednak, że metodolodzy zupełnie zarzucili weryfikowanie danych uzyskiwanych w badaniach socjologicznych. Takie próby są podejmowane do dziś. Jedną z metod - winiety zakotwiczające - prezentują kolejne rozdziały tej książki. 


\section{Nowe możliwości weryfikacji wewnętrznej. Winiety zakotwiczające jako technika obiektywizacji samoocen respondentów w badaniach sondażowych}

Sondaż od lat pozostaje jednym z głównych sposobów zbierania informacji w wielu naukach społecznych, badaniach opinii publicznej, badaniach rynkowych czy statystycznych itd. Jego mocną stroną, która decyduje o wysokiej pozycji wśród innych metod badawczych jest, po pierwsze, możliwość szybkiego zebrania i opracowania materiałów, możliwe przede wszystkim dlatego, że w narzędziu - kwestionariuszu wywiadu lub ankiety - przeważają pytania zamknięte. Przekłada się to na drugą zaletę, czyli możliwość opracowania materiałów w sposób ilościowy, a więc podania wyników w skwantyfikowanej postaci. Kwestionariusz jako rodzaj znormalizowanego formularza jest też narzędziem silnie ujednolicającym sytuację badawczą - te same pytania, w tej samej kolejności są zadawane każdemu respondentowi, który może się wypowiedzieć jedynie poprzez wybór odpowiedzi przygotowanych przez badacza. Postępowanie przebiega zatem bardzo podobnie w odniesieniu do każdej badanej jednostki, dzięki czemu materiały stają się porównywalne - zyskuje się większą pewność, że różnice w odpowiedziach respondentów wynikają z ich różnych postaw, opinii, doświadczeń, a nie różnych warunków badania. Sondaż realizuje się na dużych reprezentatywnych próbach, dlatego wyniki mogą być uogólnione na populację, z której pochodzi próba.

Trzeba mieć jednak na względzie to, że wyniki badań sondażowych są obarczone różnego rodzaju błędami. Na pierwszy rzut oka stanowi to poważny zarzut przeciw metodzie. Naiwnie jednak byłoby sądzić, że istnieją metody idealne, przynoszące rezultaty wolne od zniekształceń, dlatego właściwym przedmiotem zainteresowania powinien być raczej problem, jak dalece te zniekształcenia są rozpoznane. Wymienione cechy sondażu, $w$ tym przede wszystkim wysoki stopień standaryzacji, niewątpliwie sprzyjają prowadzeniu empirycznych badań nad metodą. Metodologia badań sondażowych jest dziedziną bardzo rozwiniętą, o długich tradycjach badawczych, 
nie tylko zresztą w USA, lecz także w Polsce. Nie będzie przesady w stwierdzeniu, że sondaż jest metodą najlepiej zbadaną, mówiąc inaczej - najbardziej metodologicznie rozpoznaną spośród innych stosowanych w badaniach społecznych.

Zgodnie z klasyczną już pozycją literaturową Roberta M. Grovesa Survey errors and survey costs (1989), błędy obarczające wyniki sondażu można podzielić na dwie zasadnicze grupy: błędy związane z próbą oraz błędy pomiaru. Do pierwszej grupy zalicza się błędy losowania próby, pokrycia oraz braku odpowiedzi, w drugiej zaś znajdują się błędy związane z osobą ankietera, respondenta, techniką gromadzenia danych oraz kwestionariuszem.

Błąd, któremu poświęcamy uwagę w tej części książki, należy do grupy błędów pomiaru i jest związany z osobą respondenta. Respondent może być źródłem różnego rodzaju zniekształceń. Prawdopodobnie do najczęściej poddawanych empirycznym badaniom w tej grupie należy błąd społecznej poprawności (ang. social desirability bias), który jest efektem skłonności do udzielania społecznie akceptowanych odpowiedzi. Błędy związane z motywacją, przetwarzaniem i przechowywaniem informacji oraz formowaniem odpowiedzi też należą do często badanych i omawianych w literaturze przedmiotu (zob. Krosnick 1991, 1999). Nas interesować będzie jeszcze inny problem - zniekształcenie polegające na zróżnicowanym sposobie posługiwania się skalą odpowiedzi do wyboru, w przypadku, kiedy pytanie wymaga od respondenta dokonania samooceny (ang. response category differential item functioning). Problem odnosi się do zjawiska zaobserwowanego już dawno, którego nie potrafiono jednak wcześniej ani zmierzyć, ani mu zaradzić. W rozdziale przedstawiamy dokładnie istotę tego błędu, a także technikę winiet zakotwiczających (ang. anchoring vignettes), która jest pomysłowym sposobem jego identyfikacji oraz korekty (King i in. 2004). Jako kompleksowa propozycja metodyczna jest to technika rozbudowana i dość złożona. Składa się na nią bowiem określony sposób zbierania danych, a także ich opracowania, przy czym jej autorzy zaproponowali aż dwie statystyczne metody analizy (korekty) danych (nieparametryczną i parametryczną) oraz opracowali komputerowe narzędzie analityczne umożliwiające wykorzystanie tych metod w praktyce - pakiet anchors w programie R (Wand i in. 2011). Biorąc pod uwagę niewielkie, jak się wydaje, zainteresowanie tą metodologiczną innowacją wśród polskich sondażystów, stawiamy sobie za cel jej dokładne przestudiowanie i omówienie.

\subsection{Błąd, jakim mogą być obciążone samooceny}

Pytanie żądające od respondenta dokonania samooceny posiadanej cechy przy użyciu skali porządkowej (np. skali Likerta) to bardzo często spotykany typ pytania kwestionariuszowego. Mimo że samoocena jest $\mathrm{z}$ gruntu subiektywna, w praktyce badawczej bywa wykorzystywana jako wskaźnik obiektywnej rzeczywistości. 
Uzasadnieniem dla takiej praktyki jest, po pierwsze, trudność w zdobyciu zewnętrznych pomiarów informujących o prawdziwych wartościach cechy. Przykładowo, chcąc uzyskać informacje na temat stanu zdrowia członków jakiejś populacji, badacze społeczni będą skłonni odwoływać się do najbardziej dostępnych im źródeł informacji, tj. poproszą samych respondentów o dokonanie samooceny w tym zakresie (np. za pomocą pytania: Jak ocenia P. swój stan zdrowia? Czy jest on bardzo dobry, raczej dobry, raczej zły, czy bardzo zły?). Alternatywą dla takiego postępowania byłoby zdobycie medycznych pomiarów, co znacznie podwyższyłoby koszty badania, o ile w ogóle byłoby możliwe (np. z powodu obostrzeń prawnych). Po drugie, są przypadki, w których nie ma alternatywy dla pytań o samoocenę. Kiedy badana jest cecha, $\mathrm{z}$ definicji związana tylko ze sferą świadomościową, to nie istnieje dla niej ani fizycznie, ani nawet potencjalnie żadne zewnętrzne źródło informacji. Przykładem może być poczucie wpływu na rządzących (ang. external political efficacy ${ }^{1}$ ) - w odniesieniu do tej cechy trudno nawet wyobrazić sobie ewentualne zabiegi badawcze, które miałyby polegać na wywołaniu określonych zachowań i pozwolić na uzewnętrznienie badanej własności tak, aby stała się mierzalna w bezpośrednim, fizycznym teście².

Wskaźnikowanie o obiektywnej, prawdziwej wartości cechy na podstawie samooceny ma swoje oczywiste ograniczenia, jakimi są chociażby zgrubność pomiaru i deklaratywny charakter danych. Przystając na te niedogodności, badacze oczekują korzyści, jaką będzie możliwość dokonywania porównań między jednostkami. Historia badań sondażowych pokazuje, że oczekiwanie to nie zawsze znajduje uzasadnienie, bowiem $\mathrm{w}$ wielu przypadkach samooceny respondentów są obarczone dodatkowym, specyficznym błędem.

Ilustracją błędu, jaki mogą zawierać samooceny, niech będzie następujący przykład: dwie osoby, którym w takim samym stopniu sprawia trudność wchodzenie po schodach, różnie oceniają swoje problemy z poruszaniem się - 90-latek ocenia je jako „łagodne”, a 40-latek jako „umiarkowane” (por. Salomon i in. 2004). Taka rozbieżność w ocenie rzeczywistości, na pozór niewyglądająca ani groźnie, ani zaskakująco, może być jednak powodem otrzymywania co najmniej zastanawiających rezultatów badań. Oto zgodnie z wynikami jednego sondażu, Chińczycy okazują się mieć większe poczucie wpływu na rządzących niż obywatele

1 W badaniach prowadzonych przez Kinga i Wanda (2006) poczucie wpływu na rządzących było mierzone za pomocą pytania żądającego dokonania samooceny: How much say do you have in getting the government to address issues that interest you? (1) no say, (2) little say, (3) some say, (4) a lot of say, (5) unlimited say. W innych badaniach sondażowych cechę tę często się mierzy stosunkiem respondentów do takich stwierdzeń jak: Przedstawiciele władz nie przejmuja się tym co myśla ludzie tacy jak ja; Ludzie tacy jak ja nie mają nic do powiedzenia w kwestii tego co robi rząd (por. Skarżyńska, Chmielewski 1994; Abramson, Aldrich 1982; Przybysz 2004; Korzeniowski 1997; Miszalska 1996).

2 Takie zachowania jak uczestnictwo w wyborach, pisanie listów i petycji do władz, angażowanie się w kampanie polityczne czy prowadzenie we własnych kręgach dyskusji na tematy polityczne są korelatami tej cechy, a nie składnikami definiensu. 
bardziej demokratycznego Meksyku. Paradoks ten zainspirował Gary’ego Kinga i jego współpracowników do opracowania prezentowanej w tej pracy techniki winiet zakotwiczających (King i in. 2004). Inne przykłady - istnieje sporo doniesień mówiących, że zależność między stanem zdrowia i jego samooceną bywa odwrotnie proporcjonalna - np. porównania między mężczyznami z Wielkiej Brytanii i Stanów Zjednoczonych (Banks i in. 2006) czy porównania między mieszkańcami różnych regionów Indii (Sen 2002, za: King i in. 2004) pokazują, że zdrowsi respondenci oceniają swój stan zdrowia gorzej niż respondenci mający więcej problemów zdrowotnych. Z punktu widzenia trafności pomiaru możemy więc mówić o wystąpieniu błędu.

W literaturze błąd ten bywa różnie nazywany i ujmowany, niemniej jego definicje są równoważne. Differential item functioning (w skrócie DIF) powstaje wtedy, gdy dwie osoby posiadające tę samą wartość cechy mają różne prawdopodobieństwa dostarczenia takiej samej odpowiedzi (Hopkins, King 2010). Wynika on z systematycznych różnic w sposobie posługiwania się odpowiedziami do wyboru, tworzącymi skalę porządkową (np. bardzo dobrze, raczej dobrze, raczej źle, bardzo źle). $\mathrm{Z}$ tego powodu bład jest dookreślany jako response category DIF, co znaczy, że jest związany tylko z rozwijającą, a nie podstawową częścią pytania, innymi słowy nie wynika on $\mathrm{z}$ różnego rozumienia treści pytania (czyli nie jest to tzw. stem DIF) (King i in. 2004; King, Wand 2006). Inne spotykane w piśmiennictwie nazwy tego błędu to reporting heterogeneity (Bago d'Uva i in. 2009) czy rating style (Grol-Prokopczyk i in. 2011). Używając języka socjologicznego, można powiedzieć, że istotą tego błędu jest to, że ludzie różnią się posiadanymi standardami oceny - mają zróżnicowane normy i oczekiwania odnośnie do tego, co to jest dobry stan (w jakiejś dziedzinie), a od jakiego poziomu zaczyna się stan zły czy niesatysfakcjonujący. Zjawisko przykładania własnych miar przy dokonywaniu oceny ma swoje źródło w uwarunkowaniach kulturowych i zróżnicowaniach społeczno-demograficznych. Jego konsekwencją jest natomiast nieporównywalność wyników (jeśli traktować je jako wskaźniki prawdziwej wartości cechy). Ten sposób ujęcia błędu oddają inne jego nazwy, takie jak interpersonal/inter-group/ cross-cultural incomparability (King i in. 2004; King, Wand 2006).

Zaproponowanym przez G. Kinga i J. Wanda remedium na response category DIF jest technika winiet zakotwiczających (King, Wand 2006; King i in. 2004). Technika ta robi maksymalny użytek $\mathrm{z}$ danych opartych na interrogacji - wykorzystuje dane wewnętrzne (sondażowe), które dzięki winietom pełnią funkcję zewnętrznej „kotwicy", czyli obiektywnego pomiaru. Metoda proponuje więc alternatywę dla zewnętrznego źródła informacji w sytuacji, gdy nie można z niego skorzystać. Dzięki możliwości odwołania się do tak rozumianego „standardu” technika pozwala nie tylko sprawdzić, czy samooceny są obarczone błędem, lecz także skorygować go. Mówiąc krócej, technika umożliwia obiektywizację samoocen.

Korekta dokonywana jest na etapie opracowania materiałów. Celem nie jest skonstruowanie idealnego pytania, które pozwalałoby wyeliminować błąd $w$ fazie formułowania odpowiedzi - uważa się, że taki cel jest niemożliwy do osiągnięcia. Mówiąc 
inaczej, nie jesteśmy w stanie zapobiegać wystąpieniu tego błędu, natomiast możemy podjąć próbę oczyszczenia z niego danych, pozwalające wyeliminować lub ograniczyć go na etapie obliczeń, gdy dysponujemy odpowiednimi materiałami.

\subsection{Konstrukcja narzędzia}

Materiały, których wymaga technika winiet zakotwiczających, obejmują odpowiedzi respondentów na pytanie żądające dostarczenia samooceny oraz odpowiedzi na pytania $\mathrm{z}$ winietami. Winiety są historyjkami, mającymi przedstawiać konkretne sytuacje hipotetycznych osób i prezentować różne poziomy badanej cechy. O winietach można inaczej powiedzieć, że są to operacyjne definicje różnych realizacji zmiennej. Zadanie, które stawiane jest przed badanym polega na tym, aby ocenił on swój poziom cechy oraz poziom cechy osoby przedstawionej w winiecie za pomocą tej samej skali. Na rysunku 1. przedstawiono strukturę przykładowego kwestionariusza, w którym zastosowano omawianą technikę.

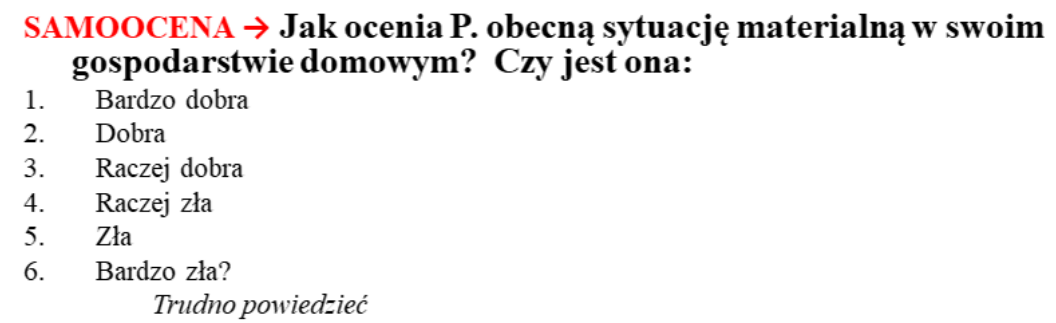

WINIETA $\rightarrow$ W rodzinie NOWAKÓW wystarcza pieniędzy na jedzenie i oplaty, ale nie stać już ich na nowe ubrania, ani sprzęty do domu. Jak P. ocenia sytuację materialną tej rodziny? Czy jest ona:

1. Bardzo dobra

2. Dobra

3. Raczej dobra

4. Raczej zła

5. Zła

6. Bardzo zła?

Trudno powiedzieć

WINIETA $\rightarrow$ Rodzinie PIOTROWSKICH bez problemu wystarcza na podstawowe wydatki. Mogą sobie także pozwolić na kupno różnych markowych produktów. W każdym miesiącu odkładają na konto okolo 2 tys. zlotych. Jak P. ocenia sytuację materialną tej rodziny? Czy jest ona:

Rysunek 1. Struktura narzędzia wykorzystującego technikę winiet zakotwiczających (na przykładzie badań nad sytuacją materialną) Źródło: opracowanie własne. 
Odpowiedź na pytanie, ile winiet powinno się zamieścić zależy od kilku czynników. Zasadniczy dylemat w podjęciu decyzji wyznacza problem - dużo informacji (więcej winiet) versus małe koszty (mniej winiet). Metoda jako taka nie narzuca ograniczeń odnośnie do liczby winiet - $\mathrm{w}$ wariancie minimum wystarczy jedna, choć nie jest to opcja polecana z uwagi na małą efektywność. Szukając rozwiązania optymalnego, należy rozważyć, z jakim rodzajem populacji mamy do czynienia. W badaniu populacji heterogenicznej (zróżnicowanej pod względem badanej cechy) będzie potrzebna większa liczba winiet niż w przypadku homogenicznej. Podobnie przypuszczenie, że członkowie populacji mogą znacząco różnić się standardami oceny jest przesłanką do zastosowania większej liczby winiet (Anchoring... 2009). Dla przykładu można podać, że w sondażach WHO, a więc prowadzonych w populacji maksymalnie zróżnicowanej, do badania jednej cechy stosuje się zwykle od 5 do 7 winiet, w niektórych przypadkach nawet 12 (Anchoring... 2009).

Problemem częściowo związanym z liczbą winiet jest kwestia ich mocy dyskryminacyjnej. Winiety o dużej mocy dyskryminacyjnej, a więc przynoszące dużo informacji, to - najogólniej rzecz ujmując - takie, które prezentują poziomy cechy występujące $\mathrm{w}$ badanej populacji oraz $\mathrm{w}$ niewielkim stopniu od nich odstające. Uzyskane dane nie będą miały żadnej wartości, jeżeli okaże się, że winiety odbiegają znacząco od sytuacji charakterystycznych dla danej zbiorowości i zupełnie nie pasują do jej członków (Anchoring... 2009). Ustalanie mocy dyskryminacyjnej winiet może nastąpić podczas badania próbnego przeprowadzonego na małej, ale reprezentatywnej próbce. Dzięki temu badaniu można porównać poszczególne zestawy i sprawdzić, czy określoną moc dyskryminacyjną da się uzyskać, stosując jakiś inny, mniej liczebny wariant.

Liczba winiet zależy też od planowanego sposobu opracowania danych. Metoda nieparametryczna wymaga zebrania pomiarów dla winiet od wszystkich jednostek w próbie. Z kolei metoda parametryczna jest bardziej efektywna pod tym względem i zakłada, że pytania $\mathrm{z}$ winietami można zadać tylko części respondentów (np. 1/4 próby). To przy okazji oznacza, że badacz mógłby w kilku podpróbkach zastosować różne zestawy winiet, zwiększając w ten sposób ich ogólną liczbę (Anchoring... 2009).

Czy istnieje jakaś zasada, która mówi o relacji między liczbą winiet a liczbą proponowanych odpowiedzi do wyboru? Zdaniem autorów techniki, nie istnieje żaden konieczny związek między tymi wielkościami - liczba winiet może być mniejsza bądź większa niż liczba punktów skali (Anchoring... 2009). W tym miejscu można spróbować uzupełnić, mówiąc, że bardziej optymalny wydaje się wariant, w którym liczba odpowiedzi do wyboru jest większa niż liczba winiet - takie rozwiązanie sprzyja wychwytywaniu różnic między winietami, jeśli są przez respondentów dostrzegane. Natomiast przy wąskim zakresie skali może się zdarzyć, że winiety postrzegane jako różniące się poziomem cechy zostaną „na siłę" tak samo ocenione (ma to większe znaczenie przy nieparametrycznej metodzie korekty błędu).

Kolejna kwestia dotyczy tego, $\mathrm{w}$ jakim porządku winiety (pytania $\mathrm{z}$ winieta$\mathrm{mi}$ ) powinny być prezentowane respondentom. Najlepszym rozwiązaniem byłoby 
zastosowanie rotacji, która powoduje, że porządek dla każdego respondenta jest wyznaczany przez mechanizm losowy. Jeżeli nie jest to możliwe, jak w przypadku badań prowadzonych za pomocą kwestionariuszy w papierowej formie, gdzie każdy respondent otrzyma zestaw z jednakową kolejnością, to należy zadbać o to, aby winiety nie były prezentowane $\mathrm{w}$ formie uporządkowanego (rosnąco lub malejąco) kontinuum. Zalecenie to podyktowane jest chęcią przeciwdziałania tendencji, w której respondent, zamiast dokonywać oceny, zacznie mechanicznie przyporządkowywać następującym po sobie winietom kolejne punkty skali (wg zasady: winieta pierwsza $\rightarrow$ odpowiedź pierwsza, winieta druga $\rightarrow$ odpowiedź druga, itd.).

Jeżeli chodzi o kolejność głównych składowych narzędzia, pierwotnie zalecano porządek: najpierw samoocena, a potem winiety (King i in. 2004; King, Wand 2006). W ostatnim czasie uzyskano empiryczne przesłanki na rzecz rozwiązania odwrotnego (Hopkins, King 2010) - zostaną one przedstawione w dalszej części pracy.

\subsection{Założenia techniki}

Zgodnie z koncepcją autorów, technika jest oparta na dwóch podstawowych założeniach. Przed ich zaprezentowaniem warto odwołać się do wyrażenia, które w uproszczony sposób przedstawia ideę metody. Zgodnie z rysunkiem 2, różnice między respondentami w samoocenie wynikają $\mathrm{z}$ dwóch powodów: różnic w zakresie prawdziwej wartości cechy oraz różnic w standardach oceny. Innymi słowy, samoocena zawiera w sobie informację o prawdziwej wartości cechy, która jest obarczona błędem. Jeśli nie mielibyśmy dodatkowego źródła informacji, nie byłoby możliwe oddzielenie od siebie tych dwóch składników. Tym dodatkowym źródłem są winiety, które mierzą błąd. Korekta polega więc na „odjęciu” od siebie tych dwóch pomiarów (wzór przedstawiony na rysunku ma wartość jedynie poglądową). Aby jednak wynikiem „różnicy” mogła być wartość prawdziwa, muszą być spełnione dwa warunki.

Pierwszy - obydwa wyrażenia odnoszące się do błędu muszą być tożsame $($ DIF przy samoocenie $=$ DIF przy winietach). To głosi założenie o konsekwencji odpowiedzi (ang. response consistency), zgodnie z którym każdy respondent przykłada konsekwentnie te same standardy oceny, kiedy ocenia siebie oraz osoby przedstawione w winietach (w skrócie - założenie RC). Przypadki, w których założenie nie będzie spełnione obejmują, zdaniem autorów, sytuacje ekstremalne - mogą one wynikać z kompleksu niższości (respondent zawsze ocenia siebie niżej niż innych), myślenia życzeniowego lub zbytniego optymizmu (reakcja odwrotna) itd. (Anchoring... 2009: 7).

Drugi - zróżnicowanie w ocenie winiet musi wynikać tylko z DIF, tzn. że (pomijając błędy losowe) różnice nie mogą wynikać z błędu polegającego na 
różnym rozumieniu treści winiety (winiety są wolne od stem DIF). Dlatego założenie o ekwiwalentności winiety (ang. vignette equivalence) głosi, że każdy respondent przypisuje treści winiety to samo znaczenie, a dokładniej - poziom cechy przedstawionej $\mathrm{w}$ winiecie jest przez każdego respondenta odbierany $\mathrm{w}$ ten sam sposób (w skrócie - założenie VE). Założenie nie będzie spełnione w przypadku, gdy w ramach badania, np. poczucia wpływu na rządzących, część respondentów uzna, że winiety opisują wpływ poprzez wybory, a część - wpływ poprzez indywidualne znajomości i koneksje (King i in. 2004: 194). Hanna Grol-Prokopczyk podaje przykład umieszczenia w winiecie osoby $\mathrm{z}$ nadwagą - w jednych kulturach może być ona uznana za kogoś, kto ma problemy zdrowotne, a w innych jako ktoś będący okazem zdrowia (2011). Ten dodatkowy przykład stanowi ważne uzupełnienie i pozwala na wyodrębnienie w założeniu VE niejako dwóch warunków.

\title{
Skąd się biorą różnice między respondentami
}

\author{
w samoocenie? \\ $\downarrow$ \\ w ocenie winiet? \\ $\downarrow$ \\ Wartość prawdziwa (A) \\ $+$ \\ DIF \\ DIF

$$
(\mathrm{A}+\mathrm{DIF})-\mathrm{DIF}=\mathrm{A}
$$ \\ Rysunek 2. Idea korekty błędu dokonywanej za pomocą winiet \\ Źródto: opracowanie własne.
}

Przykład zaproponowany przez twórców odnosi się do warunku, który można nazwać zgodnością konkretyzacji. Zgodnie z nim, sens terminu oznaczającego badaną cechę, zawarty w pytaniu o samoocenę, jest konkretyzowany (definiowany) przez badacza i respondenta za pomocą tych samych wymiarów (dostępnych doświadczeniu zjawisk). Taka zgodność w sposobie definiowania nie będzie mieć miejsca, jeśli - tu można dać kolejny przykład - badany jest problem nadużywania alkoholu, przy czym respondent, dokonując samooceny, „operacjonalizuje” go sobie jako przypadki oficjalnie nałożonych sankcji (utrata prawa jazdy, nagana w pracy itp.), a badacz w winietach ujmuje w kategoriach częstości i ilości wypijanego alkoholu. To samo znaczenie terminu musi być podzielane przez wszystkich 
- jeżeli twierdzi się, że dzięki winietom wiadomo, co respondent ma na myśli, mówiąc np. raczej dobra, to dlatego, że z tożsamości odpowiedzi (na pytanie o samoocenę i pytanie $z$ winietą) wnioskuje się o tożsamości przypadków - respondenta i osoby przedstawionej w winiecie.

Z kolei przykład H. Grol-Prokopczyk mówi o zgodności wartościowania. Jeżeli byłby rozpatrywany przypadek, w którym narzędzie składa się - przykładowo $-z$ trzech winiet, to warunek ten głosiłby, że w odpowiedziach respondentów istnieje zgoda co do tego, która winieta wyraża najniższy, która wyższy, a która najwyższy poziom cechy. Mówiąc inaczej, wszyscy osiągają jedno następujące uporządkowanie: $\mathrm{W}_{1}<\mathrm{W}_{2}<\mathrm{W}_{3}$. Należy zauważyć, że zgodność wartościowania nie wyklucza występowania DIF - warunek jest spełniony zarówno przez układ odpowiedzi „1, 2, 3”, jak i „2, 3, 5”, itd. Dopiero przy spełnieniu obu tych warunków, składających się na założenie VE, winiety tworzą jednowymiarową skalę.

Spełnienie założeń - przynajmniej częściowo - jest pod kontrolą badacza. Przytaczane niżej zalecenia, które mają wspomóc realizację założeń, można więc potraktować jako dodatkowe dyrektywy odnoszące się do konstruowania narzędzia.

Aby zwiększyć szansę spełnienia założenia o konsekwencji odpowiedzi (RC), tzn. skłonić respondenta, aby stosował taką samą miarę, kiedy ocenia siebie i osobę w winiecie, należy osobę tę przedstawić w taki sposób, aby była ona podobna do respondenta - stąd zalecenie, aby używać w winietach imion typowych dla badanej populacji i zgodnych z płcią respondenta oraz unikać szczegółów niepasujących, które odwodziłyby go od chęci postawienia się na miejscu osoby w winiecie (Anchoring... 2009).

Podstawowym warunkiem spełnienia założenia o ekwiwalentności (VE) jest przedstawienie w winietach sytuacji możliwie najbardziej jasnych i konkretnych, odnoszących się do doświadczenia - operowanie abstraktami grozi dodatkowymi rozbieżnościami w interpretacjach. Zaleca się, aby później przetestować winiety w badaniu pilotażowym w celu sprawdzenia, czy przedstawionym w nim opisom przypisywane jest spójne znaczenie (King i in. 2004).

W końcu, dla spełnienia warunku, który nazwano zgodnością konkretyzacji, albo sens terminu (odnoszącego się do badanej cechy) powinien być wyjaśniony respondentowi w pytaniu mierzącym samoocenę, albo należy zamienić kolejność i najpierw zadać pytania z winietami, a później pytanie o samoocenę. To drugie rozwiązanie zostało pozytywnie przetestowane przez autorów techniki w późniejszym czasie. Opiera się ono na wykorzystywaniu tzw. efektu kontekstu (a dokładniej - efektu asymilacji ${ }^{3}$ ), który polega na tym, że informacje z wcześniejszego pytania stają się podstawą do sformułowania odpowiedzi na pytania kolejne. Oczekuje się zatem, że winiety „narzucą” respondentowi pożądany sposób rozumienia terminu w pytaniu z samooceną (Hopkins, King 2010). W odniesieniu do tego pomysłu można jednak wysunąć pewną uwagę - w przypadku, gdy przewiduje się zastosowanie winiet jedynie dla części respondentów (co dopuszcza parametryczna metoda opracowania), pozostała część badanych nie będzie poddana działaniu uwrażliwiającego

3 Więcej na temat efektu asymilacji pisze A. Krzewińska (2006). 
kontekstu. Powstaje w tej sytuacji zasadnicza wątpliwość, czy samooceny uzyskane innymi sposobami ( $\mathrm{z}$ „bodźcem” i bez niego) są nadal porównywalne.

Założenia są empirycznie sprawdzalne, przy czym testy na spełnienie założeń RC i VE są różnie peracjonalizowane - w zależności od metody opracowania. Testowanie założenia RC zwykle jednak wymaga dostępu do obiektywnych danych. Na koniec można wspomnieć, że w ostatnim czasie nastąpił rozwój w dziedzinie konstruowania testów - inni badacze zaproponowali własne, bardziej restrykcyjne sprawdziany.

\subsection{Nieparametryczna metoda opracowania materiatów - modele relatywnych rang}

Ideę nieparametrycznej metody opracowania materiałów można łatwo przedstawić, odwołując się do przykładów. Rysunki 3-4 stanowią ilustrację odpowiedzi respondentów na pytanie żądające dostarczenia samooceny sytuacji materialnej we własnym gospodarstwie domowym oraz na pytanie z winietą (tylko jedną - dla uproszczenia przykładu). Winieta przedstawia rodzinę Nowaków, w której wystarcza pieniędzy jedynie na jedzenie i opłaty.

\section{Respondent 1}

Respondent 2

Respondent 3

SAMOOCENA: Jak ocenia P. obecną sytuację materialną w swoim gospodarstwie domowym? Czy jest ona:

\begin{tabular}{|l|} 
6. Bardzo dobra \\
5. Dobra \\
4. Raczej do bra \\
3. Raczej zła \\
2. Zła \\
1. Bardzo zła? \\
$\quad$ Trudno powiedzieć \\
\hline
\end{tabular}

6. Bardzo dobra

5. Dobra

4. Raczej dobra

3. Raczej zła

2. $\mathrm{Zla}$

1. Bardzo zła? Trudnopowiedzieć
6. Bardzo dobra

5. Dobra

4. Raczej dobra

3. Raczej zła

2. Zła

1. Bardzo zła? Trudnopowiedzieć

WINIETA: W rodzinie Nowaków wystarcza pieniędzy na jedzenie i oplaty, ale nie stać już ich na nowe ubrania, ani sprzęty do domu. Jak P. ocenia sytuację materialną tej rodziny? Czy jest ona:

6. Bardzo dobra
5. Dobra
4. Raczej dobra
3. Raczej zła
2. Zła
1. Bardzo zła?
$\quad$ Trudno powiedzieć

Samoocena $<$ winieta

$$
\mathrm{C}=\mathbf{1}
$$
6. Bardzo dobra
5. Dobra
4. Raczej dobra
3. Raczej zła
2. Zła
1. Bardzo zła? Trudno powiedzieć

Samoocena $=$ winieta $\mathrm{C}=\mathbf{2}$
6. Bardzo dobra

5. Dobra

4. Raczej dobra

3. Raczej zła

2. Zla

1. Bardzo zła? Trudno powiedzieć

Samoocena $>$ winieta $\mathrm{C}=\mathbf{3}$

Rysunek 3. Hipotetyczne odpowiedzi respondentów 1-3 Źródto: opracowanie własne. 


\section{Respondent 4}

Respondent 5

Respondent 6

SAMOOCENA: Jak ocenia P. obecną sytuację materialną w swoim gospodar-stwie domowym? Czy jest ona:

6. Bardzo dobra
5. Dobra
4. Raczej dobra
3. Raczej zła
2. Zła
1. Bardzo zła?
$\quad$ Trudno powiedzieć

6. Bardzo dobra
5. Dobra
4. Raczej dobra
3. Raczej zła
2. Zla
1. Bardzo zła?
$\quad$ Trudnopowiedzieć

6. Bardzo dobra

5. Dobra

4. Raczej dobra

3. Raczej zła

2. Zła

1. Bardzo zla? Trudno powiedzieć

WINIETA: W rodzinie Nowaków wystarcza pieniędzy na jedzenie i opłaty, ale nie stać już ich na nowe ubrania, ani sprzęty do domu. Jak P. ocenia sytuację materialną tej rodziny? Czy jest ona:

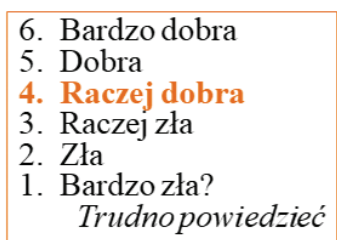

Samoocena $=$ winieta

6. Bardzo dobra
5. Dobra
4. Raczej dobra
3. Raczej zła
2. Zla
1. Bardzo zła?
$\quad$ Trudno powiedzieć

Samoocena $=$ winieta
6. Bardzo dobra
5. Dobra
4. Raczej dobra
3. Raczej zła
2. Zła
1. Bardzo zla? Trudno powiedzieć

Samoocena $=$ winieta

Rysunek 4. Hipotetyczne odpowiedzi respondentów 4-6 Źródto: opracowanie własne.

Zgodnie z rysunkiem 3., wszyscy trzej respondenci oceniają swoją sytuację tak samo jako raczej dobrą. Sugeruje to, że wartość prawdziwa cechy jest w przypadku tych trzech respondentów jednakowa. Dzięki zamieszczeniu pytania $\mathrm{z}$ winietą dostajemy nowe informacje, pozwalające na weryfikację tego wniosku. Okazuje się, że każdy respondent inaczej ocenia sytuację w rodzinie Nowaków - poziom materialny przedstawiony $\mathrm{w}$ winiecie $\mathrm{w}$ różnym stopniu satysfakcjonuje poszczególnych badanych. Innymi słowy, mają oni różne standardy oceny - najniższe standardy ma respondent 1 ., dla którego dysponowanie środkami na jedzenie i opłaty oznacza sytuację „dobrą"; z kolei najwyższe standardy ma respondent 3., dla którego taka sytuacja jest niesatysfakcjonująca i ocenia ją jako „złą”. Dotychczasowa korzyść, jaka wyniknęła z posłużenia się pytaniem $\mathrm{z}$ winietą polegała na sprawdzeniu ( $\mathrm{tu}$ - potwierdzeniu) istnienia DIF.

Następnie pytanie $\mathrm{z}$ winietą zostanie wykorzystane do skorygowania błędu. Analizując sekwencję odpowiedzi każdego respondenta dostrzegamy, że respondent 1 ocenia swoją sytuację gorzej, respondent 2. tak samo, a respondent 3. lepiej niż sytuację w rodzinie Nowaków. Informacje te są utrwalane za pomocą nowej zmiennej - skali $C$, na której ranga odzwierciedla pozycję respondenta względem winiety. Jak więc widać, prawdziwa wartość cechy jest ustalana (konstruowana) jako relacja między samooceną a winietą opisującą pewien wymierny, obiektywny stan. Zgodnie z przykładem na rysunku, skorygowana wartość cechy dla respondenta 1 . wynosi $c=1$, dla respondenta 2 . $c=2$, a respondent 3 otrzymuje rangę $c=3$. 
Na rysunku 4. przedstawiono przypadek odwrotny - wyjściowe samooceny sugerują, że sytuacja materialna w gospodarstwach domowych trzech respondentów jest różna. Odpowiedzi na pytania z winietą ujawniają, podobnie jak w poprzednim przypadku, że respondenci różnią się standardami oceny. Dzięki winietom jednocześnie wiemy, jaką sytuację mają na myśli respondenci, kiedy dokonują samooceny. W tym przypadku okazuje się, że sytuacja materialna w gospodarstwie domowym każdego z respondentów odpowiada sytuacji w rodzinie Nowaków, innymi słowy, wszyscy oni reprezentują ten sam poziom cechy $(c=2)$. Warto zauważyć, że omawiany przykład stanowi bezpośrednią ilustrację definicji błędu (DIF-u ${ }^{4}$.

Przydatny okazać się może jeszcze inny sposób zilustrowania przypadków respondentów 1-3 oraz 4-6. Na rysunkach - odpowiednio - 5. i 6. przedstawiono skalę odpowiedzi na pytanie o samoocenę. Udzielone odpowiedzi zaznaczono poprzez podkreślenie liczby odpowiadającej wybranemu przez respondenta punktowi na skali.

Górna część każdego rysunku jest ilustracją rutynowo przyjmowanego przez badaczy milczącego założenia, że respondenci nie różnią się standardami oceny. W tym układzie „linijką” do pomiaru badanego zjawiska jest po prostu dostarczona do odpowiedzi skala ocen, ponieważ dla każdego respondenta (a także badacza) rozpoczyna się ona $\mathrm{w}$ tym samym punkcie i wybrany punkt (np. 4. - raczej dobra) oznacza dla każdego to samo. Uściślając, założenie nie sprowadza się tylko do semantycznej zgodności w odniesieniu do etykiety (zgodność by nie zachodziła, gdyby np. raczej dobra była rozumiana przez niektórych jako „chyba dobra”, „średnia”, itp.). Chodzi także o to, co „stoi za” etykietą, czyli o konkretny, fizyczny stan rzeczy, który w odniesieniu do interesującej badacza cechy pojawia się w wyobrażeniu respondenta. Korespondencja między etykietą a stojącym za nią obrazem mogłaby przykładowo zrealizować się w ten sposób, że raczej dobra sytuacja materialna oznacza dla każdego respondenta stan, w którym pieniędzy wystarcza na jedzenie i opłaty, ale już nie na nowe ubrania, sprzęt do domu i na to, by oszczędzać. W świetle tego, co zostało napisane, brak zróżnicowania standardów oceny jawi się jako dość mocne założenie.

W dolnej części każdego rysunku graficznie oddano zjawisko występowania zróżnicowanych standardów oceny. Skala odpowiedzi przekazana responden-

4 Kontynuując przykład z rysunku 4, można przeanalizować, jak wyglądałyby wyniki samooceny skorygowanej, jeżeli błąd by nie wystąpit, a więc wszyscy respondenci w ten sam sposób oceniliby winietę. Na ile nowa zmienna odzwierciedlitaby pierwotne uporządkowanie samoocen? Odpowiedź na to pytanie zależy od mocy dyskryminacyjnej winiety. W omawianym przykładzie winieta miałaby największą moc dyskryminacyjną, jeśli wyrażany przez nią poziom cechy zostałby przez wszystkich oceniony jako „zły” - wtedy kontinuum samooceny skorygowanej byłoby w całości pokryte i jednocześnie rozkład byłby równomierny $(R 1 \rightarrow c=3 ; R 2 \rightarrow c=2 ; R 3 \rightarrow c=1)$. Winieta miałaby najmniejszą moc dyskryminacyjną, gdyby w ocenie respondentów wyrażała „dobrą” albo „bardzo dobrą” sytuację materialną - wtedy rozkład skumulowałby się w jednym punkcie i każdy respondent otrzymałby tę samą rangę $(c=1)$. Jak więc widać, mimo braku błędu, pomiar na skali samooceny skorygowanej może tracić na dokładności, jeżeli winieta nie ma zdolności różnicowania. 
tom przestaje być dla badacza „linijką”, użytecznym narzędziem pomiaru badanej cechy, ponieważ każdy z nich posługuje się nią inaczej. Wprawdzie wszyscy tak samo rozumieją etykiety skali, ale dla każdego zaczyna się ona w innym punkcie, tak, jakby pozbawiona była wspólnego dla wszystkich zera - skale „rozjeżdżają się”. Badacz potrzebuje w tej sytuacji nowej „linijki” z jakimś wspólnym punktem odniesienia. Kluczowa jest tu rola winiet (winiety), dzięki którym badacz sprawdza, czy wystąpił problem zróżnicowanych standardów oceny, chwyta ewentualny „rozjazd” oraz zyskuje nową „linijkę” (skala C).

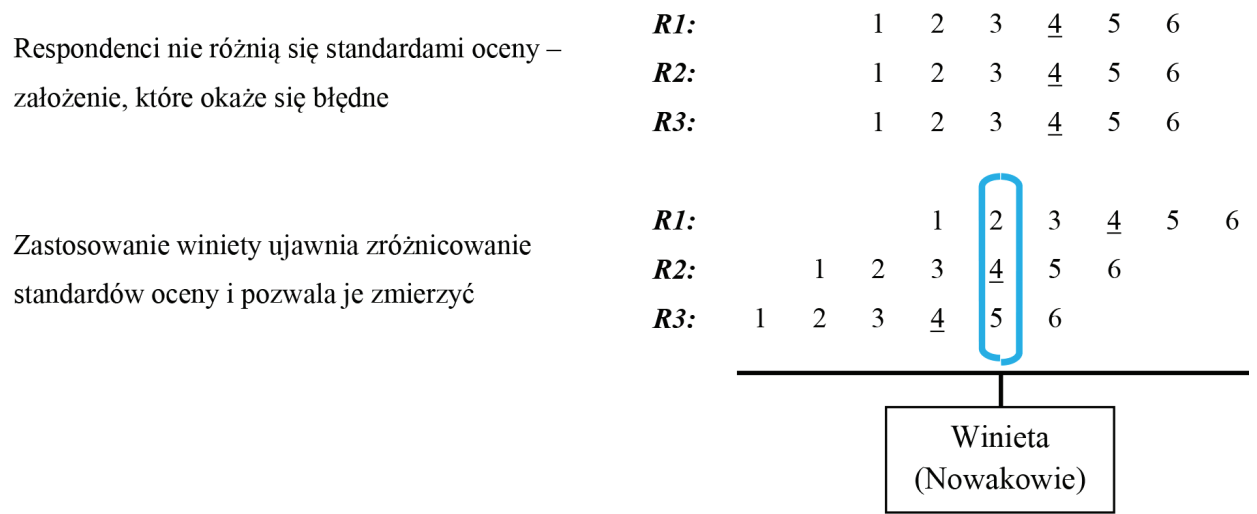

Rysunek 5. Ilustracja idei działania winiet na przykładzie odpowiedzi respondentów 1-3

Źródło: opracowanie własne na podstawie danych z rys. 3

Respondenci nie różnią się standardami oceny założenie, które okaże się błędne

Zastosowanie winiety ujawnia zróżnicowanie standardów oceny i pozwala je zmierzyć

$\begin{array}{lllllll}R 4: & 1 & 2 & 3 & \underline{4} & 5 & 6 \\ \text { R5: } & 1 & \underline{2} & 3 & 4 & 5 & 6 \\ \text { R6: } & 1 & 2 & 3 & 4 & 5 & 6\end{array}$

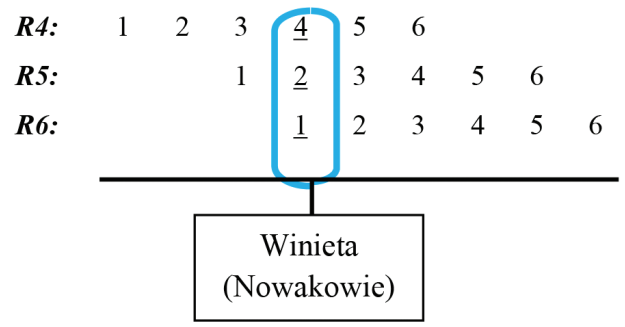

Rysunek 6. Ilustracja idei działania winiet na przykładzie odpowiedzi respondentów 4-6 Źródło: opracowanie własne na podstawie danych z rys. 4.

Sposób konstrukcji zmiennej $C$, czyli skali samooceny skorygowanej lub, jeszcze inaczej, samooceny zakotwiczonej w winietach, dokładniej przedstawiono na rys. 7. Wartości nowo powstałej zmiennej, wyrażające natężenie cechy u respondenta, można ogólnie ująć jako poniżej poziomu prezentowanego w winiecie, na 
tym samym poziomie albo powyżej tego poziomu. Jak widać, zmienna informuje o RELACJACH między rangami, czyli między samooceną i oceną winiety (ocenami winiet) i jest wynikiem operacji polegającej na przekodowaniu danych. Przyjmuje się zasadę, zgodnie z którą wyższe punkty skali mają świadczyć o większym natężeniu cechy.

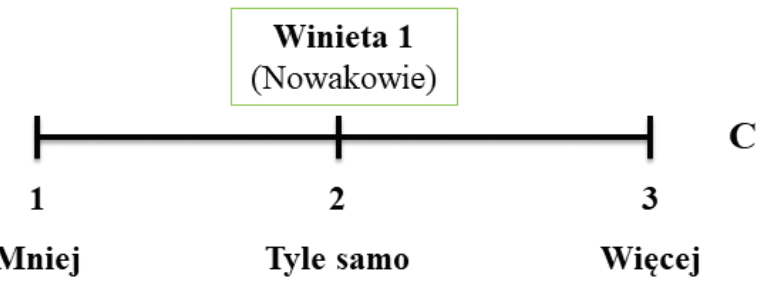

Winiety ułożone w porządku odzwierciedlającym natężenie cechy:

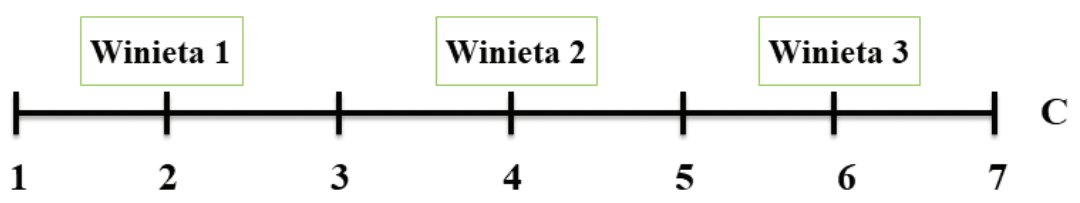

Rysunek 7. Konstrukcja zmiennej C w przypadku jednej oraz trzech winiet Źródło: opracowanie własne.

Metodę tę można też przedstawić w sposób bardziej sformalizowany (King, Wand 2006: 5). Niech $J$ oznacza liczbę winiet, $y$ odpowiedź na pytanie żądające dokonania samooceny, a $z_{1}, \ldots, z_{J}$ oznaczają odpowiedzi na pytania wymagające oceny winiet. Rozpiętość skali $C$ (liczba punktów na skali) określona jest wzorem $2 J+1$. Dla respondentów, którzy uporządkowali winiety zgodnie z zasadą $z_{j-1}<z_{j}$, gdzie $j=2, \ldots, J$, skala $C$ samooceny skorygowanej przyjmuje następujące wartości:

$$
C=\begin{aligned}
& 2 \\
& \ldots \\
& 2 J+1
\end{aligned}\left\{\begin{array}{l}
\text { jeśli } y<z_{1} \\
\text { jeśli } y=z_{1} \\
\text { jeśli } z_{1}<y<z_{2} \\
\ldots \\
\text { jeśli } y>z_{1}
\end{array}\right.
$$

Jak unaocznia powyższy fragment, gdy użyto dwóch lub więcej pytań z winietami, kontinuum samooceny skorygowanej musi być oparte na jednym konkretnym porządku ułożenia winiet. Na rysunku 7., upraszczając nieco, powiedziano, że chodzi o porządek wyznaczony przez poziom natężenia cechy. W praktyce nie 
musi być to uporządkowanie dokonane ex ante przez badacza - ostatecznym źródłem porządku są dominujące oceny respondentów, które mogą (lecz nie muszą) pokrywać się z wyobrażeniem badacza na ten temat.

Wraz ze wzrostem liczby winiet, narzędzie potencjalnie przynosi więcej informacji (zyskuje większą moc dyskryminacyjną) - rozszerza się zakres skali, co pozwala lepiej różnicować członków populacji pod kątem badanej cechy. Z drugiej strony, duża liczba winiet to nie tylko zwiększone koszty badania, lecz także pewne potencjalne trudności na etapie opracowania materiałów, polegające na wystąpieniu tzw. powiązań oraz błędnych uporządkowań. Powiązanie (ang. tie) oznacza sytuację, w której respondent przypisuje tę samą rangę co najmniej dwóm winietom (wg respondenta, winiety nie różnią się pod względem natężenia cechy). Przez błędne uporządkowanie (ang. misordering) rozumie się przypadek, w którym respondent przypisuje winietom rangi w sposób, który nie odpowiada oczekiwanemu (lub dominującemu) uporządkowaniu (wg respondenta, winieta 2. przedstawia niższy poziom cechy niż winieta 1.).

Powiązania oraz błędne uporządkowania stanowią problem $\mathrm{z}$ dwóch powodów. Po pierwsze, takie odstępstwa (od „poprawnego” uszeregowania) nie muszą układać się w jeden wzór - odpowiedzi respondentów zwykle tworzą co najmniej kilka różnych uporządkowań winiet. Zadaniem badacza staje się więc ustalenie tego dominującego, w którym jest najmniejsza liczba zaburzeń. Poza tym samo pojawienie się odstępstw powinno wzbudzić czujność badacza, gdyż przypadki te mogą świadczyć o niespełnieniu założenia VE. Można przypomnieć - metoda zakłada, że nawet jeżeli każdy respondent „posługuje się” swoim specyficznym DIF-em, to jednak istnieje zgoda co do tego, która winieta wyraża najwyższy poziom cechy, która w kolejności niższy, itd. (DIF nie uniemożliwia osiągnięcia jednego uporządkowania ${ }^{5}$ ). Jednocześnie jednak wystąpienie powiązań i błędnych uporządkowań nie może być rygorystycznie traktowane jako test na spełnienie założenia VE, ponieważ metoda nieparametryczna nie jest w stanie uchwycić odstępstw o charakterze losowym. Należy też wziąć pod uwagę, że narzędzia, w których liczba winiet jest większa niż liczba odpowiedzi do wyboru, będą w sposób nieunikniony generować powiązania. $\mathrm{W}$ efekcie przyjmuje się tu dość liberalne podejście, zgodnie z którym dla pary winiet liczba błędnych uporządkowań nie powinna przekroczyć liczby uporządkowań poprawnych. Akceptowane jest też rozwiązanie polegające na usunięciu (z obliczeń) winiet, dla których odnotowano dużą liczbę odstępstw (por. Wand i in. 2011).

Drugi problem pojawia się wtedy, gdy samoocena respondenta „wpada” w powiązanie lub błędne uporządkowanie (respondent przypisuję tę samą rangę sobie, co powiązanym lub błędnie uporządkowanym winietom, względnie - samoocena leży pomiędzy błędnie uporządkowanymi winietami). Taka sytuacja powoduje, że wynik samooceny skorygowanej staje się przedziałem wartości (wektorem), np. $c=\{2,3,4,5\}$, a nie pojedynczą wartością skalarną. Problem ten jest dokładnie

5 Zob. rysunki 5-6. 
unaoczniony w tabeli 7., w której przedstawiono wszystkie możliwe warianty uporządkowań dla dwóch winiet.

Tabela 7. Wartości estymatora $C$ dla wszystkich możliwych układów odpowiedzi obejmujących samoocenę oraz ocenę dwóch winiet (przy oczekiwanym uporządkowaniu $z_{1}<z_{2}$ )

\begin{tabular}{|c|c|c|c|c|c|c|c|}
\hline $\begin{array}{c}\text { Numer } \\
\text { przykładu }\end{array}$ & $\begin{array}{c}\text { Układ } \\
\text { odpowiedzi }\end{array}$ & $\boldsymbol{y}<\boldsymbol{z}_{\mathbf{1}}$ & $\boldsymbol{y}=\boldsymbol{z}_{\mathbf{1}}$ & $\boldsymbol{z}_{\mathbf{1}}<\boldsymbol{y}<\mathbf{z}_{\mathbf{2}}$ & $\boldsymbol{y}=\mathbf{z}_{\mathbf{2}}$ & $\boldsymbol{y} \boldsymbol{>} \boldsymbol{z}_{\mathbf{2}}$ & $\boldsymbol{c}$ \\
\hline 1 & $y<z_{1}<z_{2}$ & 1 & 0 & 0 & 0 & 0 & $\{1\}$ \\
\hline 2 & $y=z_{1}<z_{2}$ & 0 & 1 & 0 & 0 & 0 & $\{2\}$ \\
\hline 3 & $z_{1}<y<z_{2}$ & 0 & 0 & 1 & 0 & 0 & $\{3\}$ \\
\hline 4 & $z_{1}<y=z_{2}$ & 0 & 0 & 0 & 1 & 0 & $\{4\}$ \\
\hline 5 & $z_{1}<z_{2}<y$ & 0 & 0 & 0 & 0 & 1 & $\{5\}$ \\
\hline 6 & $y<z_{1}=z_{2}$ & 1 & 0 & 0 & 0 & 0 & $\{1\}$ \\
\hline 7 & $y=z_{1}=z_{2}$ & 0 & 1 & 0 & 1 & 0 & $\{2,3,4\}$ \\
\hline 8 & $z_{1}=z_{2}<y$ & 0 & 0 & 0 & 0 & 1 & $\{5\}$ \\
\hline 9 & $y<z_{2}<z_{1}$ & 1 & 0 & 0 & 0 & 0 & $\{1\}$ \\
\hline 10 & $y=z_{2}<z_{1}$ & 1 & 0 & 0 & 1 & 0 & $\{1,2,3,4\}$ \\
\hline 11 & $z_{2}<y<z_{1}$ & 1 & 0 & 0 & 0 & 1 & $\{1,2,3,4,5\}$ \\
\hline 12 & $z_{2}<y=z_{1}$ & 0 & 1 & 0 & 0 & 1 & $\{2,3,4,5\}$ \\
\hline 13 & $z_{2}<z_{1}<y$ & 0 & 0 & 0 & 0 & 1 & $\{5\}$ \\
\hline
\end{tabular}

Źródto: (King, Wand 2006: 6).

Przykłady od 1 do 5 obejmują przypadki, w których winiety są poprawnie uporządkowane i niepowiązane, dzięki czemu wynik samooceny skorygowanej jest wartością skalarną (autorzy operują też nazwą uncensored value).

Wiersze 6-8 odnoszą się do powiązań, a przypadki 9-13 do błędnych uporządkowań. Jeżeli samoocena jest „uwikłana” w jedno z takich zaburzeń (przykłady: $7,10,11,12$ ), to estymator C przyjmuje wartość, która jest wektorem (autorzy operują też nazwą censored value). Wynikiem odstępstwa może być też wartość skalarna, o ile samoocena jest wyższa bądź niższa od stanowiących grupę powiązanych lub błędnie uporządkowanych winiet (przykłady: 6, 8, 9, 13). Tę ostatnią sytuację traktuje się jako stosunkowo niegroźną - uważa się za zrozumiałe i akceptowalne, że respondent może nie mieć umiejętności dobrego rozróżniania przypadków, które go nie dotyczą (King, Wand 2006: 6).

Dopóki metoda "generuje" wyniki w postaci wektorów, jest mało skuteczna, a trzeba wziąć pod uwagę, że w praktyce liczba takich wyników może dotyczyć około połowy obserwacji. W tej sytuacji powstaje pytanie, czy można uporać się 
z tym problemem i w jakiś sposób zastąpić wartości wektorowe wartościami skalarnymi. Parametryczny suplement tej metody udostępnia cztery rozwiązania w tym zakresie.

Pierwszy sposób polega na pominięciu obserwacji wektorowych (ang. omitting interval values). Jakkolwiek jest to metoda najprostsza, jest jednocześnie mało efektywna, ponieważ wiąże się z utratą części danych. Co ważniejsze, stoi za nią bardzo mocne założenie mówiące, że obserwacje wektorowe nie wpływają na rozkład badanej cechy (osoby, których wynik jest przedziałem, nie różnią się od osób z wynikiem skalarnym), dlatego można je usunąć na zasadzie ubytków losowych ${ }^{6}$ (Wand i in. 2011).

Drugim rozwiązaniem jest równomierna alokacja (ang. uniform allocation within intervals) - wartości z przedziału (wektora) są rozmieszczane równomiernie wśród wszystkich respondentów z danym wynikiem wektorowym (King, Wand 2006: 7). Można pokazać, na czym dokładniej polega metoda, omawiając schemat postępowania w odniesieniu do jednego respondenta z przykładowym wynikiem $c=\{2,3,4\}$, dla którego chcielibyśmy obliczyć rozkład częstości zmiennej $C$. Przed rozlokowaniem wartości tworzących wektor do klas skalarnych musi być uwzględniona zasada, zgodnie z którą jeden respondent ma jeden „głos”, niezależnie od tego, z ilu wartości składa się jego wynik. W omawianym przykładzie "głos” respondenta zostanie podzielony na trzy części, z której każda otrzyma tę samą wagę. Względna częstość w każdej klasie $(2,3,4)$ będzie zatem wynosiła 0,33. Wynika to z wzoru:

$$
p_{j, m: n}=1 /(n-m+1) \quad \text { dla } \quad j \in\{m, \ldots, n\}
$$

gdzie $p_{j}$ oznacza proporcję obserwacji w klasie $j$ zmiennej $C($ dla $j=1, \ldots, 2 J+1)$, natomiast $m$ to koniec, a $n$ początek przedziału (Wand i in. 2011).

Jak widać, wariant równomiernej alokacji dąży do rozkładu płaskiego (efekt ten byłby najsilniejszy w przypadku, gdyby każdy z respondentów miał wynik będący wektorem o najszerszym możliwym przedziale). To z kolei znaczy, że ten rodzaj dystrybucji „pracuje” na rzecz jak największej mocy dyskryminacyjnej winiet. Kiedy respondenci są równomiernie rozmieszczeni na kontinuum, to rozkład odpowiada równaniu:

$$
p_{1}=p_{2}=\cdots p_{2 J+1}=\frac{1}{2 J+1}
$$

Warto uzupełnić, że miarą mocy dyskryminacyjnej winiet, a więc ich zdolności do różnicowania respondentów, czy jeszcze inaczej - informatywności, jest entropia $(H)$, zdefiniowana za pomocą wzoru:

6 MCAR - missing completely at random. 


$$
H\left(p_{1}, \cdots, p_{j}\right)=-\sum_{(j=1)}^{(2 J+1)} p_{j} \ln \left(p_{j}\right)
$$

gdzie przyjęto, że $-0 \ln (0) \equiv 0$ (ponieważ $\lim _{a \rightarrow 0}+a \ln (1 / a)=0$ ) (King, Wand 2004: 12).

$H$ jest równe zero, wtedy i tylko wtedy, gdy wyniki wszystkich respondentów wpadają do jednej klasy zmiennej $C$ - winieta(y) nie ma wtedy mocy różnicowania $^{7} . H$ przyjmuje wartość maksymalną i równą $\ln (2 J+1)$, kiedy $p_{j}=1 /(2 J+1)$, dla wszystkich $j$ - wtedy winieta(y) ma największą zdolność różnicowania, co daje rozkład równomierny. Jak wynika $\mathrm{z}$ wzoru, maksymalna wartość $H$ rośnie wraz $\mathrm{z}$ liczbą winiet. Omawiany tu wariant dystrybucji można więc inaczej nazwać alokacją przy maksimum entropii. Rozmieszczeniem steruje zasada, aby osiągnąć największą wartość $H$ przy zadanym zestawie winiet.

Trzeci mechanizm - alokacji przy minimum entropii (ang. minimum entropy) - realizuje przeciwną tendencję: wartości wektorowe rozkładane są w sposób odpowiadający najmniejszej mocy dyskryminacyjnej winiet. Algorytm jest zaprojektowany na przyporządkowanie jak największej liczby obserwacji wektorowych do jednej kategorii $j$ zmiennej $C$ (mieszczącej się w zakresie wektora), a konkretnie do tej, która generuje najmniejszą wartość $H$ (Wand i in. 2011).

I w końcu ostatni wariant alokacji, który opiera się na analizie regresji. Jest to uogólnienie modelu probitowego dla zmiennych porządkowych, który został dostosowany do rozwiązania problemu wartości wektorowych - censored ordered probit model - autorska metoda G. Kinga i J. Wanda (King, Wand 2006; Wand i in. 2011). Tym razem dystrybucja wartości $z$ wektora następuje przy uwzględnieniu informacji o proporcji „podobnych” respondentów, dla których wyniki są skalarne (w zakresie wartości wektora). Badacz określa zmienne, ze względu na które ma być szukane to podobieństwo (ang. explanatory variables). Regresja nastawiona jest głównie na prognozę, choć oczywiście istnieje możliwość wykorzystania jej także w celach opisowych (na tych samych zasadach jak w przypadku zwykłego modelu probitowego dla zmiennych porządkowych).

Punktem wyjścia jest tradycyjny model, w którym $C_{i}^{*}$ (dla respondenta $i=1, \ldots, n)$ jest ciągłą i nieobserwowalną zmienną zależną, a $x_{i}$ jest wektorem zmiennych wyjaśniających (do identyfikacji modelu - bez wyrazu wolnego). Zmienna $C_{i}^{*}$ jest modelowana jako mająca warunkowy rozkład normalny ze średnią $x_{i} \beta$ i wariancją równą 1 . Gdyby zmienna $C_{i}^{*}$ była obserwowalna, estymatorem największej wiarygodności beta byłby współczynnik z liniowej regresji $Y_{i}$ względem $x_{i}$.

7 Przykładem może być pytanie z winietą, w którym respondent proszony jest o ocenę kondycji fizycznej osoby, która w tygodniu przebiega dwa maratony. Pytanie zastosowane w badaniu np. populacji dorosłych Polaków przyniosłoby najpewniej rezultat, zgodnie z którym wszyscy badani oceniliby swą kondycję jako gorszą od osoby przedstawionej w winiecie. Jak więc widać, przy konstruowaniu narzędzia nie chodzi o to, aby winiety przedstawiały wszystkie dające się pomyśleć sposoby realizacji cechy, ale tylko te realnie występujące w badanej zbiorowości i nieznacznie od nich różne. 
Zmienna $C_{i}$ obserwowana jest poprzez specyficzny mechanizm, który w przypadku wartości skalarnych wygląda następująco:

$$
C_{i}=c \text { jeżeli } \tau_{(c-1)} \leq C_{i}^{*}<\tau_{c}
$$

przy czym $\tau_{c}$ oznaczają progi (gdzie $\tau_{0}=-\infty ; \tau_{2 J+1}=\infty ; \tau_{c-1}<\tau_{c}$ dla $c=1, \ldots, 2 J+1$ ).

Prawdopodobieństwo obserwowania wyniku w kategorii $c$ opisane jest wzorem:

$$
\operatorname{Pr}\left(C_{i}=c \mid x_{i}\right)=\int_{\tau_{(c-1)}}^{\tau_{c}} N\left(C_{i}^{*} \mid x_{i} \beta\right) d y
$$

Dla wartości wektorowych, równania (5) i (6) zostają zmodyfikowane:

$$
\begin{aligned}
& C_{i}=\{m, \ldots, n\} \text { jeżeli } \tau_{m-1} \leq C_{i}^{*}<\tau_{n} \\
& \operatorname{Pr}\left(C_{i}=\{m, \ldots, n\} \mid x_{1}\right)=\int_{\tau_{m-1}}^{\tau_{n}} N\left(C_{i}^{*} \mid x_{1} \beta\right) d y
\end{aligned}
$$

Powyższe sposoby obliczania prawdopodobieństwa autorzy określają jako bezwarunkowe (ang. unconditional) i proponują jeszcze jedno rozwiązanie.

$$
p_{i j: m: n}=\frac{\operatorname{Pr}\left(C_{i}=j \mid x_{i}\right.}{\operatorname{Pr}\left(C_{i}=\{m, \ldots, n\} \mid x_{i}\right.} \text { dla } j \in\{m, \ldots, n\}
$$

Nowa metoda wyliczenia prawdopodobieństwa, posiadająca lepszą odporność, będzie warunkować prawdopodobieństwo wystąpienia kategorii $c$ od obserwowanej wartości $c_{i}$, i stąd określana jest jako warunkowa (ang. conditional). W tym podejściu, suma prawdopodobieństw normalizowana jest do jedności w obrębie $c_{i}$ oraz do zera poza $c_{i}$. Dla skalarnych wartości $c_{i}$ wyrażenie po prostu zwraca obserwowaną kategorię. Dla wartości wektorowych równanie (9) wyznacza prawdopodobieństwo dla kategorii w obrębie $C_{i}=m, \ldots, n$, gdzie suma prawdopodobieństw wynosi 1.

$\mathrm{Z}$ proponowanych czterech metod rozwiązania problemu występowania wartości wektorowych najbardziej godną polecenia jest, wg autorów, analiza regresji. Wykorzystanie innych sposobów nie może odbywać się automatycznie, ale po uwzględnieniu stojących za nimi założeń i rozważeniu ich adekwatności w stosunku do posiadanych danych empirycznych. Z uwagi na to, że oddziaływanie założeń dotyczy tylko wartości wektorowych (usuwanych ze zbioru bądź na różne sposoby rozlokowywanych do klas skalarnych), oddziaływanie to, a więc zarazem ryzyko błędu, będzie tym większe, im mniej uzyskano na początku skalarnych wartości $c_{i}$. Taki układ będzie też skutkował znacznie różniącymi się od siebie histogramami skonstruowanymi wg poszczególnych metod. 
Przyjmując, że analiza regresji jest metodą najmniej ryzykowną, rozkłady obliczone za pomocą innych sposobów mogą być też uznane za swego rodzaju układy porównawcze. Wtedy dystrybucja na podstawie modelu regresji pozwalałaby sprawdzić, czy któreś z założeń stojących za pozostałymi rozwiązaniami jest trafne. Przykładem mogą być wyniki z rysunku 8 - nie obserwuje się tu podobieństwa między histogramem będącym efektem analizy regresji a pozostałymi wykresami, stąd wniosek, że żadne z branych pod uwagę założeń nie jest prawdziwe.

Bez obserwacji wektorowych

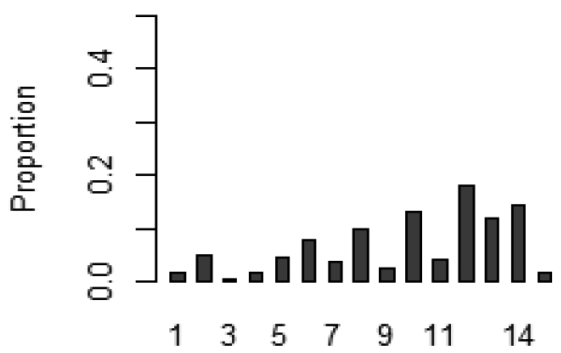

C

\section{Alokacja wg censored ordered probit}

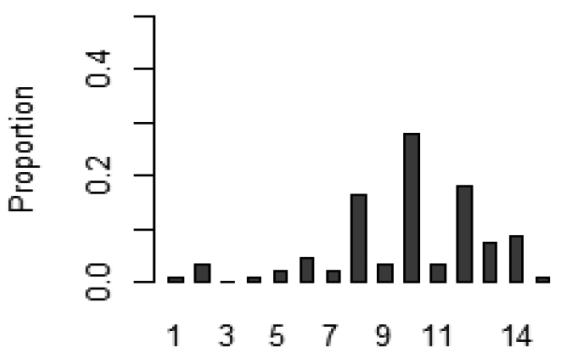

C
Alokacja równomierna

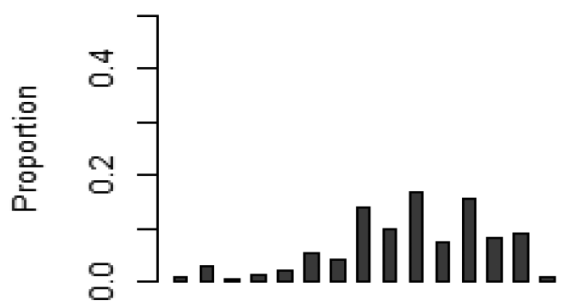

$\begin{array}{lllllll}1 & 3 & 5 & 7 & 9 & 11 & 14\end{array}$

C

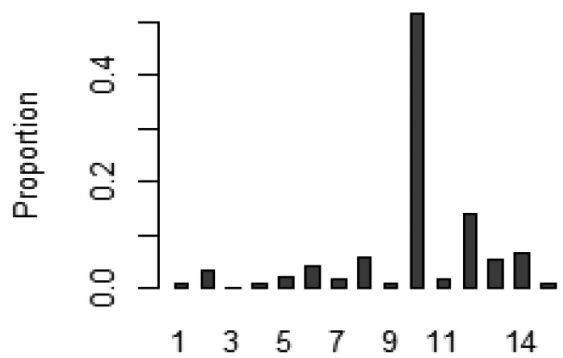

$\mathrm{C}$

Rysunek 8. Empiryczne ilustracje czterech sposobów rozwiązania problemu wartości wektorowych

Źródto: opracowanie własne.

Należy dodać, że rozkłady zmiennej $C$ warto również analizować w podgrupach utworzonych przez zmienną, która wyjaśnia zróżnicowanie standardów oceny (np. typ kultury, narodowość). Jeżeli taka zmienna niosłaby dodatkowo informację o prawdziwych wartościach badanej cechy (np. wiedza o reżimie politycznym i swobodach obywatelskich w Chinach oraz w Meksyku pozwala traktować Chińczyków jako mających mniejszy wpływ na rządzących, a Meksykan - większy), to analizy takie można potraktować jako sprawdzian założenia RC. 


\subsection{Parametryczna metoda opracowania materiałów - model CHOPIT}

Parametryczna metoda opracowania materiałów ma kilka znaczących zalet, które powodują, że generalnie przewyższa ona nieparametryczny odpowiednik. Jak już wcześniej sygnalizowano, omawiając inne problemy - parametryczny wariant pociąga za sobą, po pierwsze, znacznie mniejsze koszty, gdyż dopuszcza zastosowanie winiet jedynie w odniesieniu do losowej podpróbki respondentów albo tylko w badaniu próbnym. To się przekłada na drugą potencjalną zaletę, jaką jest możliwość zastosowania różnych wariantów narzędzia w kilku podpróbach. Po trzecie, uwzględnia błędy o charakterze losowym (ang. random measurement error), jakimi mogą być obarczone odpowiedzi respondentów (King i in. 2004).
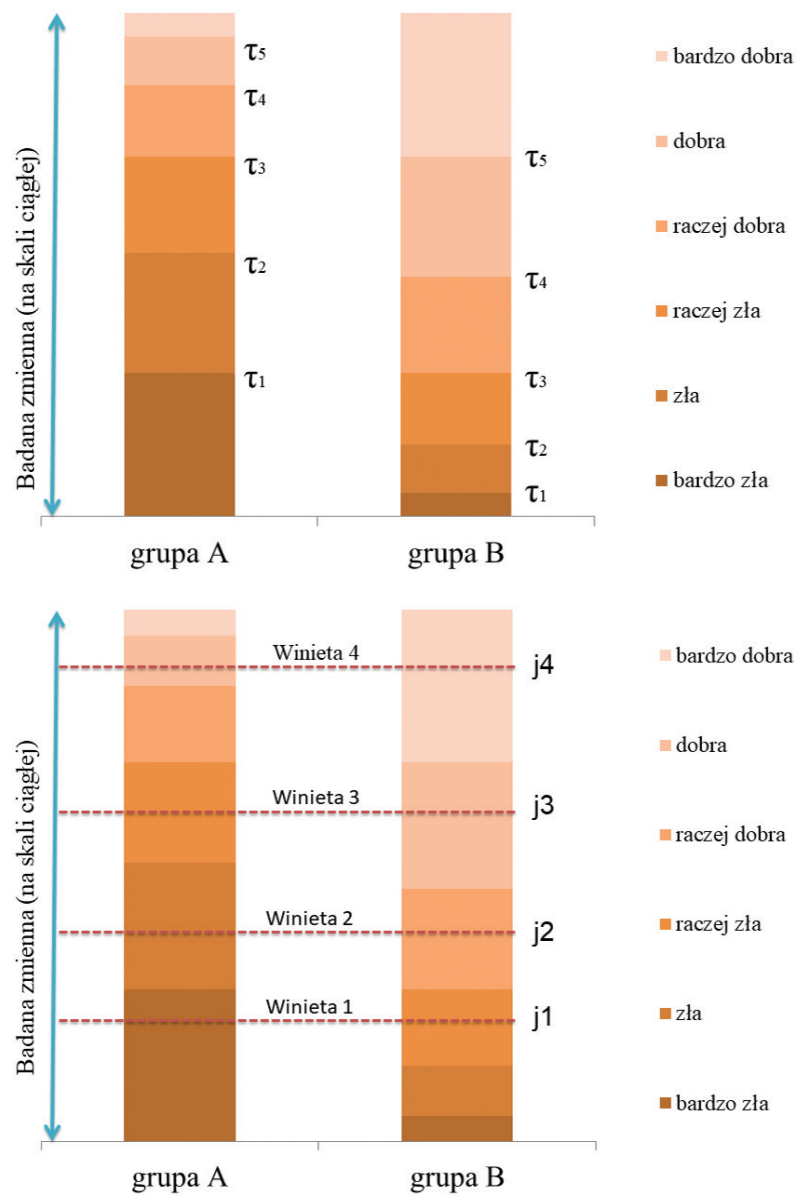

Rysunek 9. Idea korygowania błędu za pomocą metody parametrycznej Źródło: opracowanie własne. 
Compound hierarchical ordered probit model (CHOPIT) jest kolejną autorską metodą G. Kinga i jego współpracowników, która - podobnie jak censored ordered probit model - „wyrasta” z probitowego modelu regresji dla zmiennych porządkowych. Rysunek 9., wraz z komentarzem, może stanowić krótkie wprowadzenie do tej metody.

CHOPIT pozwala na modelowanie błędu jako progów (ang. treshholds) $\left(\tau_{1}, \tau_{2}, \ldots\right)$, którymi różnią się jednostki bądź grupy w postrzeganiu poszczególnych punktów skali. Zgodnie z danymi na rysunku 9., grupa A ma wyżej ulokowane progi (a więc wyższe standardy oceny) w porównaniu z grupą $\mathrm{B}$ - np. to, co dla grupy B oznacza (już) sytuację raczej złą, dla grupy A oznacza (ciągle) sytuację bardzo złą. Technicznie rzecz ujmując, progi są więc punktami odcięcia między dwiema kategoriami odpowiedzi na skali. Identyfikacja tych progów i korekta błędu jest możliwa dzięki winietom. Dla nich również wylicza się wartości (wartości prawdziwe dla osób przedstawionych w winietach, $j_{1}, j_{2}, \ldots$ ), które z założenia (VE) są stałe dla wszystkich respondentów. Wielkości te estymuje się na skali ciągłej i latentnej.

W ramach modelu, dla każdego respondenta i pytania wyróżniana jest wartość prawdziwa (ang. actual) i wartość postrzegana (ang. perceived) badanej cechy, która jest mierzona na skali ciągłej. Na wartość postrzeganą składa się wartość prawdziwa oraz błąd losowy (ang. random measurement error). Wartości prawdziwe są porównywalne, choć nieobserwowalne. Podobnie wartości postrzegane nie mogą być obserwowane, ale są porównywalne, niemniej tylko na poziomie średniej. Model zawiera również wartość zadeklarowaną (ang. reported), która podlega obserwacji i jest mierzona na skali porządkowej. Ponieważ wartości zadeklarowane są obarczone błędem systematycznym (DIF-em), nie mogą być porównywane.

Należy przejść do bardziej formalnego omówienia modelu. Składa się on z dwóch komponentów, z których jeden odnosi się do samooceny, a drugi do winiet.

Komponent modelu odnoszący się do samooceny. Niech $\mu_{i}$ oznacza wartość prawdziwą cechy $\mathrm{u}$ respondenta $i(i=1, \ldots, n)$ mierzoną na skali ciągłej, o nieograniczonych krańcach, jednowymiarowej, na której wyższe wartości świadczą o większym natężeniu cechy. Respondent $i$ postrzega $\mu_{i} z$ losowym błędem.

$$
Y_{i s}^{*} \sim N\left(u_{i}, 1\right)
$$

reprezentuje postrzeganą wartość cechy przez $i$-tego respondenta dla pytania o samoocenę $s(s=1, \ldots, S)$.

Wartości prawdziwe, którymi różnią się jednostki, są funkcją zmiennych wyjaśniających $X_{i}$ oraz niezależnych błędów losowych (nieskorelowanych i normalnych reszt) $\eta_{i}$,

$$
\mu_{i}=X_{i} \beta+\eta_{i}
$$

z parametrem beta (do identyfikacji modelu - bez wyrazu wolnego), gdzie 


$$
\eta_{i} \sim N\left(0, \omega^{2}\right)
$$

reszty są modelowane jako niezależne od $X_{i}$. Jeżeli $S=1$ (co odpowiada jednemu pytaniu o samoocenę), reszty są pomijane, ponieważ wariancja nie może być ustalona.

Wartość $Y_{i s}^{*}$ postrzegana zamienia się $\mathrm{w}$ wartość zadeklarowaną $y_{i s}$ poprzez mechanizm

$$
y_{i s}=k \quad \text { jeśli } \quad \tau_{i s}^{k-1} \leq Y_{i s}^{*}<\tau_{i s}^{k}
$$

gdzie $y_{i s}$ oznaczają progi $\left(\tau_{i s}^{0}=-\infty, \tau_{i s}^{K^{s}}=\infty, \tau_{i s}^{k-1}<\tau_{i s}^{k}\right)$ indeksowane dla kategorii odpowiedzi $k=1, \ldots, K_{s}$ oraz pytań o samoocenę $\left.s=1, \ldots, S\right)$.

Wartości progów, którymi różnią się jednostki, są funkcją zmiennych wyjaśniających $V_{i}$ (które mogą pokrywać się z $X_{i}$ ) oraz nieznanych wektorów parametrów $\gamma_{s}\left(\right.$ ich elementami są wektory $\left.\gamma_{s}^{k}\right)$ :

$$
\begin{aligned}
\tau_{i s}^{1} & =\gamma_{s}^{1} V_{i} \\
\tau_{i s}^{k} & =\tau_{i s}^{k-1}+e^{\left.\gamma_{s}^{k} V_{i}\right)}\left(k=2, \ldots, K_{s}-1\right)
\end{aligned}
$$

Komponent modelu odnoszący się do winiet. Niech $j_{j}$ oznacza prawdziwą wartość cechy mierzonej na skali ciągłej o nieograniczonych krańcach dla osoby przedstawionej $\mathrm{w}$ winiecie $j(j=1, \ldots, J)$. Zgodnie z założeniem VE, poziom cechy, który przedstawia winieta jest podzielany przez wszystkich badanych, dlatego symbol $j_{j}$ nie będzie indeksowany dla respondenta.

Skoro metoda dopuszcza przebadanie winietami jedynie losowej części respondentów, to tacy badani będą indeksowani odrębnym symbolem $l(l=1, \ldots, N)$. Respondent $l$ postrzega $j_{j}$ jedynie $\mathrm{z}$ błędem losowym:

$$
Z_{l j}^{*} \sim N\left(\theta_{j}, \sigma^{2}\right)
$$

Przyjmuje się, że założenie VE będzie spełnione, jeżeli średnie wartości winiet $\left(j_{1}, j_{2}, \ldots\right)$ będą uporządkowane rosnąco (lub malejąco). Do sprawdzianu przydatna też będzie informacja o wielkości wariancji $\sigma^{2}$ (King i in. 2004: 198-199).

Wartość postrzegana winiety zamienia się w wartość zadeklarowaną za pomocą mechanizmu:

$$
z_{l j}=k \quad \text { jeśli } \quad \tau_{l 1}^{k-1} \leq Z_{l j}^{*}<\tau_{l j}^{k}
$$

z progami określonymi przez te same parametry $\gamma_{s}$ oraz te same zmienne wyjaśniające $V_{i}$ co w równaniu (14), z tym, że dla respondentów $l$ : 


$$
\begin{aligned}
& \tau_{l 1}^{1}=\tau_{l}^{1} V_{i} \\
& \tau_{l 1}^{k}=\tau_{l 1}^{k-1}+e^{\gamma_{1}^{k} V_{i}} \quad\left(k=2, \ldots, K_{1}-1\right)
\end{aligned}
$$

Równanie (17) jest sformalizowanym zapisem założenia RC.

Jakkolwiek do diagnozy o wystąpieniu DIF wystarczy analiza wartości progów dla poszczególnych jednostek czy grup, to badacze zwykle wzbogacają swoje analizy o wyniki „klasycznego” modelu probitowego dla zmiennych porządkowych (Bakker i in. 2014; Kristensen, Johansson 2008). Jest to naśladowanie ścieżki, wg której postępowali G. King i in. (2004) w swoim „założycielskim” artykule, wykazując, że CHOPIT, w odróżnieniu od ordered probit, jest zdolny skorygować DIF. Zestawienie wyników obydwu modeli - bazowego i korygującego - jest więc jeszcze innym sposobem zmierzenia błędu.

Ludzie mogą doświadczać tych samych sytuacji, znajdować się w tym samym stanie lub położeniu czy mieć te same cechy co inni, a jednak inaczej je oceniać - ta z jednej strony mało odkrywcza, z drugiej socjologicznie inspirująca konstatacja odnosi się do zjawiska, które jest istotnym zagrożeniem dla trafności pomiaru w badaniach sondażowych i jednym ze źródeł tego, co Jan Lutyński określił mianem pozornej standaryzacji. Zwrócił on uwagę, że kategoryzowanie rzeczywistości za pomocą pytań kwestionariusza, a następnie jej kwantyfikowanie poprzez zliczanie odpowiedzi tego samego typu jest zabiegiem sensownym, o ile jednakowym odpowiedziom odpowiadają jednakowe zjawiska (Lutyński 1994: 123). Błąd, któremu poświęciłyśmy uwagę w tym rozdziale, czyli differential item functioning, uderza w to złożenie, prowadząc do pozornej standaryzacji, przy której jednakowe odpowiedzi nie muszą oznaczać jednakowych zjawisk, a różne odpowiedzi mogą odnosić się do tych samych zjawisk. Trzeba mieć przy tym na względzie, że owo zjawisko zróżnicowanej percepcji jednego stanu rzeczy nie zawsze jest problemem i grozi powstaniem błędu. Zagrożenia takiego nie ma, gdy subiektywne odbicie obiektywnej rzeczywistości interesuje badacza jako zjawisko samo w sobie i pozostaje dla niego ostatecznym przedmiotem dociekań. Natomiast problem powstaje, jeśli zakłada się lub oczekuje, że subiektywna rzeczywistość będzie pozostawać w dość ścisłym związku z obiektywną, dlatego pytając o tę pierwszą można dowiedzieć się czegoś o drugiej. Być może zresztą dla części badaczy istnienie takiego związku stanowi milczące założenie, które ugruntowane jest na przekonaniu o możliwości poznania „nagich faktów”. Charakterystyczne dla takiego podejścia jest pojawiające się w konfrontacji z terenem zdziwienie, że „odbiór rzeczywistości empirycznej może aż tak od niej odstawać" (King i in. 2004: 192).

Do rozwiązania problemu stworzonego przez zjawisko zróżnicowanych standardów oceny wykorzystano wcześniej znane już w badaniach winiety. Warto podkreślić, że winiety - funkcjonujące czasami pod niepozorną nazwą „historyjki” 
- są narzędziem o bardzo dużym potencjale, mającym szereg aplikacji. Pozostając tylko w obszarze badań ilościowych, trzeba powiedzieć, że winiety mają zastosowanie w badaniach pilotażowych, gdzie są wykorzystywane do rozpoznawania desygnatów, jakimi respondenci oznaczają terminy teoretyczne używane w pytaniach (Martin 2006). Inne, bodaj jeszcze cenniejsze zastosowanie winiet ma miejsce na polu badań eksperymentalnych, a także w obrębie różnych modyfikacji łączących eksperyment $\mathrm{z}$ badaniem sondażowym dla pozyskania profitów właściwych dla każdej z tych metod (wysokiej trafności wewnętrznej eksperymentu oraz wysokiej trafności zewnętrznej sondażu dzięki realizacji badania na reprezentatywnej próbie). Winiety służą tu do zaaranżowania przed badanym pewnej hipotetycznej sytuacji, na którą ma zareagować po usłyszeniu pytania, wybierając odpowiedź z dostarczonej listy (np. skali Likerta). Użyteczność winiet polega w tym przypadku na tym, że dają one możliwość zbadania wpływu większej liczby czynników oraz interakcji między nimi, zaś same winiety tworzy się tak, aby zawarte w nich opisy stanowiły kombinacje wartości użytych czynników (przegląd podejść i możliwości w tej dziedzinie zawiera dostarcza praca Atzmüler, Steiner 2010).

Natomiast w technice winiet zakotwiczających wykorzystuje się jeszcze inny zasób możliwości „historyjek”. Tym razem winiety służą do skonstruowania alternatywnej skali do pomiaru badanego zjawiska, która - w odróżnieniu od pierwotnej skali odpowiedzi do wyboru - nie jest obciążona pozorną standaryzacją. Dzieje się tak, ponieważ winiety dają możliwość ujawnienia informacji o fizycznym stanie rzeczywistości, który respondent ma na myśli, kiedy dokonuje jego oceny. Tak więc możemy np. dowiedzieć się, że dobre mieszkaniowe warunki dla rozwoju dziecka to nie to samo dla respondenta A i respondenta B, skoro pierwszy zadowala się posiadaniem przez dziecko własnego łóżka (co opisano w winiecie X), a drugi własnego pokoju (co opisano w winiecie Y). Wiedza ta jest warunkiem przejścia ze skali tworzonej przez odpowiedzi (nie dającej możliwości sensownych porównań) do skali tworzonej przez fizyczne zjawiska lub stany (umożliwiającej porównania między badanymi). Przejście na tę drugą skalę, która tworzy układ umożliwiający uporządkowanie jednostek ze względu na badaną cechę, jest tytułowym zakotwiczaniem pomiaru. Jak widać, dokonuje się ono w dwojakim sensie - dzięki winietom i w winietach.

Na koniec podkreślić trzeba, że wartość pomysłu G. Kinga i jego współpracowników jest tym większa, że dane pozwalające na uwolnienie wyników od błędu zostały otrzymane wewnętrzną, a nie zewnętrzną drogą. Winiety dostarczające danych weryfikujących są elementem badania sondażowego, dlatego należą do tego samego procesu otrzymywania informacji, co dane podlegające weryfikacji. Kontynuując tę myśl, można uznać winiety zakotwiczające za technikę analiz weryfikacji wewnętrznej, z tym zastrzeżeniem, że chodzi o możliwie szerokie rozumienie terminu, który wprowadził J. Lutyński, a nie o jego autorską koncepcję weryfikacji wewnętrznej (zob. Lutyński 1975). Na podobnej zasadzie można uznać wypróbowany w Polsce przez Antoniego Sułka eksperyment $\mathrm{z}$ listą (ang. unmatched count technique) za technikę weryfikacji tego samego rodzaju (Sułek 2012). Obie metody 
są zresztą świetnym przykładem pomysłowości badaczy i znaczących, choć nie tak łatwo dostrzegalnych możliwości, jakie tkwią w danych sondażowych - jak się okazuje nie muszą to być tylko dane wymagające weryfikacji, ale także mające zdolność weryfikowania.

Jakkolwiek omówiona tu technika zapowiada się bardzo obiecująco, to jej ostateczna ocena - tak jak każdej nowej techniki - powinna opierać się dodatkowo na empirycznych danych pochodzących $z$ badań z jej wykorzystaniem. W tym przypadku postulat ten ma nawet większe znaczenie, ponieważ technika winiet zakotwiczających opiera się na dwóch dość mocnych założeniach. Jeżeli nie byłyby one spełnione, oczekiwana korekta błędu nie nastąpi, a zabiegi analityczne mogą być potencjalnie źródłem dodatkowego błędu. Dlatego - by odwołać się do tytułu serii, w której ukazuje się ta publikacja - w tym przypadku nie wystarczy technikę winiet zakotwiczających wypróbować. Potrzebna jest także metodologiczna anali$\mathrm{za}$ - tu akurat poprowadzona pod kątem spełnienia założeń. 


\section{Rozdział 3}

\section{Empiryczne zastosowania techniki winiet zakotwiczających}

Technika winiet zakotwiczających, służąca do korekty błędu powstającego w następstwie przykładania przez respondentów zróżnicowania standardów w trakcie dokonywania samooceny (King i in. 2004), wzbudziła duże zainteresowanie nie tylko badaczy społecznych. Przede wszystkim stworzyła nowe szanse w badaniach epidemiologicznych, gdzie wiele własności dotyczących zdrowia bada się za pomocą samooceny, gdyż jest to jedyny sposób ich poznania albo mniej kosztowny od medycznych testów. Szczególne znaczenie ma to w badaniach międzynarodowych, takich jak prowadzony przez WHO World Health Survey, gdzie problem kulturowego zróżnicowania standardów oceny występuje z całą mocą. Jeśli chodzi o obszar związany ze zdrowiem, technika winiet zakotwiczających była już używana do badania takich cech jak: zdolność poruszania się, ostrość wzroku, zdolność koncentracji i zapamiętywania, dobrostan psychiczny, problemy ze snem, problemy z nadużywaniem alkoholu, ból, problemy ze słuchem, oddychaniem itp. (Salomon i in. 2004; King i in. 2004; Grol-Prokopczyk i in. 2011; Wilgenburg van 2010; Soest i in. 2011).

Sami autorzy techniki unaocznili, że winiety mogą mieć zastosowanie na polu badań politologicznych. Ich studia dotyczyły poczucia wpływu na rządzących i wolności wypowiedzi (King i in. 2004; King, Wand 2006). Z kolei R. Bakker wraz ze współpracownikami badali, czy eksperci z różnych krajów posługują się w ten sam sposób skalą lewicowości-prawicowości w ocenie partii politycznych (2014).

Winiety zaczęli też wykorzystywać socjologowie. Badano np. przyzwolenie na łapownictwo, ulokowanie na drabinie społecznej pod względem sytuacji materialnej, więzi społeczne w środowisku szkolnym oraz autonomię kobiet w podejmowaniu decyzji dotyczących liczby dzieci (http://gking.harvard.edu/vign/eg).

Jeszcze inny obszar zastosowania winiet wiąże się z funkcjonowaniem instytucji, $\mathrm{w}$ jego obrębie podjęto studia m.in. nad zadowoleniem $\mathrm{z}$ usług świadczonych przez placówki medyczne i skutecznością działania instytucji administracji publicznej (http://gking.harvard.edu/vign/eg), zadowoleniem z warunków pracy (Kristensen, Johansson 2008). 
Część badań z wykorzystaniem winiet zakotwiczających ma cel substantywny - technikę traktuje się wtedy jako środek, za pomocą którego można uzyskać wartościowe, wolne od błędu rezultaty badań. W większości tych prac stosuje się parametryczną metodę opracowania materiałów, a same materiały najczęściej pochodzą z badań międzynarodowych. Druga część studiów ma cel metodologiczny, co oznacza, że sama technika - jej procedury, a głównie założenia stają się właściwym przedmiotem badań. Realizacja tego ostatniego celu często prowadzi do nowych propozycji testów, a co za tym idzie do opracowania nowych metod statystycznych i odpowiadającego im komputerowego oprogramowania (zagadnienia te nie będą tu jednak szczegółowo omawiane).

\subsection{Cel badań i baza materiałowa}

Zrealizowane przez jedną z autorek tego opracowania badanie jest - najprawdopodobniej - pierwszym w Polsce przypadkiem zastosowania winiet zakotwiczających. Z tego powodu celem badania było przede wszystkim wypróbowanie tej techniki oraz wstępne rozpoznanie, dla jakich zmiennych może wystąpić błąd nieporównywalności samoocen, a przede wszystkim odniesienie się do problemu spełnienia założeń techniki przy użyciu metod zaproponowanych przez G. Kinga i J. Wanda. Mówiąc inaczej, oprócz praktycznego zapoznania się ze specyfiką metody i jej wymogami, badanie podjęto z myślą o przeprowadzeniu ostrożnej próby określenia warunków jej stosowalności.

Materiał zebrano w 2011 r podczas realizacji projektu Wszechnica Skierniewic$k a^{1}$, którego celem było zbadanie rynku edukacyjnego na terenie subregionu skierniewickiego i dostarczenie oferty szkoleniowej dla mającej powstać Wszechnicy Skierniewickiej jako jednostki formalnego kształcenia ustawicznego działającej przy PWSZ w Skierniewicach. Biorąc pod uwagę ten cel, technikę winiet zakotwiczających zastosowano w odniesieniu do dwóch własności ankietowanych: ich sytuacji materialnej oraz potrzeby doskonalenia własnych kwalifikacji zawodowych.

Na wybór wymienionych cech miały wpływ także inne czynniki. Aby odnieść się do problemu spełnienia założenia o konsekwencji odpowiedzi (RC) (zob. rozdział 2), wymagane jest posiadanie informacji o prawdziwych wartościach cechy, względnie - dobrze przybliżających je wskaźników. Wybór sytuacji materialnej jako badanej cechy podyktowany był możliwością zadania dodatkowego pytania o wielkość osiąga-

1 Projekt realizowany w okresie 1.03.2011-30.04.2012 i współfinansowany ze środków UE w ramach EFS; kierownik projektu: dr Elżbieta Stokowska; koordynator prac badawczych: dr hab. Elżbieta Psyk-Piotrowska, prof. UŁ; kierownik działu realizacji badań terenowych: dr Katarzyna Grzeszkiewicz-Radulska. 
nego dochodu. W przypadku potrzeby doskonalenia własnych kwalifikacji zawodowych, wybór zmiennej pełniącej funkcję zewnętrznego kryterium był mniej oczywisty - uznano, że stosunkowo najlepiej tę funkcję będzie pełnić zmienna uwzględniająca zarówno dotychczas podjęte działania w zakresie dokształcania, jak i plany na przyszłość (konstrukcja zmiennej została dokładnie przedstawiona w dalszej części rozdziału).

Materiał stanowiły wypowiedzi respondentów zebrane za pomocą indywidualnego wywiadu kwestionariuszowego PAPI. Badając sytuację materialną, pytania zadano zgodnie z kolejnością: samoocena oraz 7 pytań z winietami. Do każdego pytania była dołączona ta sama, 6-punktowa skala odpowiedzi. W przypadku potrzeby dokształcania, narzędzie skonstruowano w podobny sposób - najpierw zadano pytanie o samoocenę, a następnie 5 pytań $\mathrm{z}$ winietami. Skale $\mathrm{z}$ odpowiedziami do wyboru również liczyły 6 punktów. Odpowiedź „trudno powiedzieć” nie była odczytywana przez ankietera - zaznaczano ją, kiedy respondent sam takiej udzielił.

$\mathrm{Z}$ uwagi na papierową wersję narzędzia nie stosowano zabiegu rotowania winiet osobno dla każdego respondenta - winiety zostały wszystkim respondentom zaprezentowane w tej samej kolejności, jednak nie były uporządkowane pod względem natężenia cechy (konstrukcję narzędzi przedstawiają załączniki 1 i 2). Pytania $\mathrm{z}$ winietami zadano wszystkim respondentom, umożliwiając w ten sposób opracowanie materiałów zarówno metodą parametryczną, jak i nieparametryczną.

Badanie zostało zrealizowane na kwotowej próbie $(n=1000)$ mieszkańców subregionu skierniewickiego, będących w wieku produkcyjnym i jednocześnie po upłynięciu wieku przypadającego na czas formalnego kształcenia (25-59 lat w przypadku kobiet oraz 25-64 lata w przypadku mężczyzn). Próbę dobrano pod względem trzech kryteriów: płci, wieku i miejsca zamieszkania, a wykorzystanym źródłem informacji o łącznym rozkładzie płci i wieku w poszczególnych gminach były dane Głównego Urzędu Statystycznego za rok 2009.

Materiały opracowano w programie R, głównie przy wykorzystaniu pakietu anchors (Wand i in. 2011). Czynności przygotowawcze (założenie zbioru, wstępne transformacje zmiennych itp.) wykonano w programie SPSS.

\subsection{Wyniki badania sytuacji materialnej}

Zgodnie z wcześniejszą wzmianką, na zmienną pełniącą funkcję niezależnego wskaźnika sytuacji materialnej wybrano dochód przypadający miesięcznie na jedną osobę w gospodarstwie domowym². Oczywiście zmienna ta nie jest ide-

2 Pytanie brzmiało: A biorq̨c pod uwagę zarobki ze wszystkich źródeł wszystkich domowników, ile wynosi przeciętny dochód netto (na rękę) przypadajacy na jedna osobę w gospodarstwie domowym? (pytanie otwarte) 
alnym źródłem informacji o sytuacji materialnej w gospodarstwie domowym, a jedynie jej przybliżeniem - zakładamy tu, że możliwie najlepszym w porównaniu $\mathrm{z}$ innymi zmiennymi $\mathrm{w}$ zbiorze, niemniej jako deklaracja jest narażona na różnego rodzaju zniekształcenia (pomyłki w rachunkach, świadome zawyżenia lub zaniżenia itd.) oraz odmowy udzielenia odpowiedzi. Naśladując sposób postępowania autorów metody, zmienną tę przekształcono w dwuwartościową. Uwzględniając rozkład pierwotnej zmiennej, dużą liczbę braków danych oraz potencjalne mechanizmy zniekształceń danych, do dalszych analiz wykorzystano tylko obserwacje należące do I (100-900 zł) oraz III grupy tercylowej dochodu (1,5-8 tys. zł). Uznano, że w ten sposób udało się wydzielić grupy osób - odpowiednio - o mniejszym i większym dochodzie, choć kosztem tego zabiegu była utrata części obserwacji (liczebność próby zmniejszyła się ostatecznie do $\mathrm{n}=568$ ). Wartości wybranych miar rozkładu zmiennej przed transformacją przedstawiono w tabeli 8 .

Tabela 8. Wybrane statystyki rozkładu zmiennej dochód miesięczny na jedną osobę $w$ gospodarstwie domowym

\begin{tabular}{|c|c|c|}
\hline \multicolumn{2}{|c|}{ Statystyka } & Wartość \\
\hline \multicolumn{2}{|c|}{ Średnia } & 1380,14 \\
\hline \multicolumn{2}{|c|}{ Mediana } & 1100,00 \\
\hline \multicolumn{2}{|c|}{ Dominanta } & 1000,00 \\
\hline \multicolumn{2}{|c|}{ Odchylenie standardowe } & 983,06 \\
\hline \multicolumn{2}{|c|}{ Skośność } & 2,19 \\
\hline \multicolumn{2}{|c|}{ Kurtoza } & 7,29 \\
\hline \multicolumn{2}{|c|}{ Minimum } & 100 \\
\hline \multicolumn{2}{|c|}{ Maksimum } & 8000 \\
\hline \multirow{5}{*}{ Percentyle } & 25 & 700 \\
\hline & 33 & 900 \\
\hline & 50 & 1100 \\
\hline & 67 & 1500 \\
\hline & 75 & 1700 \\
\hline \multicolumn{2}{|c|}{ N ważne } & 780 \\
\hline \multicolumn{2}{|c|}{ Braki danych } & 220 \\
\hline
\end{tabular}

Źródto: opracowanie własne. 


\subsubsection{Ustalenie dominującego wzoru uporządkowania winiet}

Analizę danych za pomocą metody nieparametrycznej powinna poprzedzać wstępna diagnostyka winiet, która ma na celu zapoznanie się z występującymi wzorami ich uporządkowania oraz wybór takiego wzoru, który dominuje i wywołuje najmniejszą liczbę zaburzeń (tzw. powiązań i błędnych uporządkowań). Diagnostyka ta pozwala też na ustosunkowanie się do założenia o ekwiwalentności winiety (VE) (zob. wcześniejszy rozdział).

Sposób, w jaki skonstruowano winiety oraz ich porządek, który w założeniu powinien odzwierciedlać natężenie badanej cechy przedstawiono w tabeli 9. Przyjęto w niej zasadę, że im wyższa ranga winiety, tym lepsza sytuacja materialna. Uporządkowanie to stanowi punkt wyjścia do dalszych analiz, mających na celu ustalenie, jaki wzór dominuje - czy ze sposobem porangowania winiet przez badacza zgadza się większość respondentów.

Tabela 9. Założone przez badacza uporządkowanie winiet dotyczących sytuacji materialnej

\begin{tabular}{|c|c|c|c|c|c|c|c|}
\hline Winieta & $\mathbf{1 / e /}$ & $\mathbf{2} / \mathbf{d} /$ & $\mathbf{3 / c /}$ & $\mathbf{4 / \mathbf { b }} /$ & $\mathbf{5 / f} /$ & $\mathbf{6 / g} /$ & $\mathbf{7 / a /}$ \\
\hline Środki na żywność & $+/-$ & + & + & + & + & + & + \\
\hline Środki na czynsz & - & $+/-$ & + & + & + & + & + \\
\hline $\begin{array}{c}\text { Środki na nowe } \\
\text { ubrania/sprzęty }\end{array}$ & - & - & - & $+/-$ & + & + & + \\
\hline Oszczędności & - & - & - & - & - & $+/-$ & + \\
\hline
\end{tabular}

Źródto: opracowanie własne.

Pierwszy wgląd w uzyskane dane daje tabela 10. z wynikami prezentującymi rozkład odpowiedzi na pytania z winietami. Dodatkowo wartości średnich pozwalają na wstępną orientację, czy przyjęty ex ante porządek winiet jest podzielany przez respondentów. Docelowym źródłem informacji na ten temat jest jednak dopiero tabela 11., która mówi o odsetkach poprawnych oraz błędnych uporządkowań, a także powiązań między każdą parą winiet.

Tabela 10. Rozkład odpowiedzi na pytania z winietami dotyczącymi sytuacji materialnej

$(n=568)$

\begin{tabular}{|c|c|c|c|c|c|c|c|c|}
\hline Winieta & $\begin{array}{c}\mathbf{1 .} \\
\text { bardzo } \\
\text { zta }\end{array}$ & $\begin{array}{c}\mathbf{2 .} \\
\text { zta }\end{array}$ & $\begin{array}{c}\mathbf{3 .} \\
\text { raczej } \\
\text { zła }\end{array}$ & $\begin{array}{c}\mathbf{4} . \\
\text { raczej } \\
\text { dobra }\end{array}$ & $\begin{array}{c}\mathbf{5 .} \\
\text { dobra }\end{array}$ & $\begin{array}{c}\mathbf{6 .} \\
\text { bardzo } \\
\text { dobra }\end{array}$ & $\begin{array}{c}\text { Braki } \\
\text { danych }\end{array}$ & Średnia \\
\hline 1 & 2 & 3 & 4 & 5 & 6 & 7 & 8 & 9 \\
\hline $1 / \mathrm{e} /$ & 501 & 54 & 10 & 1 & 1 & 0 & 1 & 1,14 \\
\hline $2 / \mathrm{d} /$ & 256 & 239 & 66 & 5 & 1 & 0 & 1 & 1,68 \\
\hline
\end{tabular}


Tabela 10 (cd.)

\begin{tabular}{|c|c|c|c|c|c|c|c|c|}
\hline 1 & 2 & 3 & 4 & 5 & 6 & 7 & 8 & 9 \\
\hline $3 / \mathrm{c} /$ & 24 & 139 & 297 & 85 & 15 & 2 & 6 & 2,88 \\
\hline $4 / \mathrm{b} /$ & 1 & 16 & 139 & 279 & 118 & 7 & 8 & 3,92 \\
\hline $5 / \mathrm{f} /$ & 3 & 18 & 108 & 319 & 104 & 12 & 4 & 3,95 \\
\hline $6 / \mathrm{g} /$ & 0 & 1 & 19 & 190 & 284 & 72 & 2 & 4,71 \\
\hline $7 / \mathrm{a} /$ & 0 & 0 & 0 & 43 & 157 & 365 & 3 & 5,57 \\
\hline
\end{tabular}

Źródło: opracowanie własne.

Tabela 11. Wyniki diagnostyki winiet pod kątem zaburzeń dla uporządkowania 1234567 $(n=551)$

\section{Macierz 1}

\begin{tabular}{|c|c|c|c|c|c|c|c|}
\hline Winieta & $\mathbf{< 1}$ & $\mathbf{< 2}$ & $\mathbf{< 3}$ & $\mathbf{< 4}$ & $\mathbf{< 5}$ & $\mathbf{< 6}$ & $\mathbf{<}$ \\
\hline 1 & & 0,499 & 0,947 & 0,991 & 0,985 & 0,996 & 0,998 \\
\hline 2 & 0,005 & & 0,897 & 0,989 & 0,956 & 0,996 & 0,998 \\
\hline 3 & 0,002 & 0,007 & & 0,831 & 0,757 & 0,935 & 0,993 \\
\hline 4 & 0,000 & 0,000 & 0,013 & & 0,274 & 0,615 & 0,929 \\
\hline 5 & 0,000 & 0,004 & 0,051 & 0,243 & & 0,670 & 0,922 \\
\hline 6 & 0,000 & 0,000 & 0,007 & 0,062 & 0,015 & & 0,684 \\
\hline 7 & 0,000 & 0,000 & 0,002 & 0,004 & 0,002 & 0,033 & \\
\hline
\end{tabular}

Komórki w trójkącie nad przekątną $\left(p_{i j}\right)$ informują jaki odsetek stanowią przypadki poprawnych uporządkowań między wybraną parą winiet, np. $p_{12}=0,499$ mówi o udziale respondentów, którzy winiecie 1 przypisali niższą rangę niż winiecie 2 . Komórki w trójkącie pod przekątną $\left(p_{j i}\right)$ informują, jaki odsetek stanowią przypadki błędnych uporządkowań (misorderings) między wybraną parą winiet, np. $p_{21}=0,005$ mówi o udziale respondentów, którzy winiecie 2 przypisali wyższą rangę niż winiecie 1 .

\section{Macierz 2}

\begin{tabular}{|c|c|c|c|c|c|c|c|}
\hline Winieta & $\mathbf{1}$ & $\mathbf{2}$ & $\mathbf{3}$ & $\mathbf{4}$ & $\mathbf{5}$ & $\mathbf{6}$ & $\mathbf{7}$ \\
\hline 1 & 2 & 3 & 4 & 5 & 6 & 7 & 8 \\
\hline 1 & & 0,494 & 0,946 & 0,991 & 0,985 & 0,996 & 0,998 \\
\hline 2 & 0,495 & & 0,889 & 0,989 & 0,953 & 0,996 & 0,998 \\
\hline 3 & 0,051 & 0,096 & & 0,819 & 0,706 & 0,927 & 0,991 \\
\hline 4 & 0,009 & 0,011 & 0,156 & & 0,031 & 0,554 & 0,926 \\
\hline
\end{tabular}




\begin{tabular}{|c|c|c|c|c|c|c|c|}
\hline 1 & 2 & 3 & 4 & 5 & 6 & 7 & 8 \\
\hline 5 & 0,015 & 0,040 & 0,192 & 0,483 & & 0,655 & 0,920 \\
\hline 6 & 0,004 & 0,004 & 0,058 & 0,323 & 0,316 & & 0,652 \\
\hline 7 & 0,002 & 0,002 & 0,005 & 0,065 & 0,076 & 0,283 & \\
\hline
\end{tabular}

Komórki w trójkącie nad przekątną $\left(p_{i j}-p_{j i}\right)$ informują o różnicy między liczbą poprawnych i błędnych uporządkowań. Wartości ujemne oznaczają przewagę błędnych uporządkowań. Komórki w trójkącie pod przekątną $\left(1-p_{i j}-p_{j j}\right)$ informują, jaki odsetek stanowią przypadki powiązań (ties) między wybraną parą winiet, np. $1-p_{12}-p_{21}=0,495$ mówi o udziale respondentów, którzy przypisali tę samą rangę winiecie 1 i 2 .

Źródło: opracowanie własne.

Wyniki zamieszczone w tabeli 11 . opierają się na danych dla 551 respondentów (n), gdyż obserwacje, dla których odnotowano co najmniej jeden brak danych w zakresie zmiennych odnoszących się do winiet zostają automatycznie usunięte. Analiza danych w tabeli pozwala sformułować wniosek, że przypadki błędnych uporządkowań dotyczyły zwykle tylko winiet „sąsiadujących”, a ich liczba była niewielka - największy odsetek $(0,24)$ odnotowuje się dla pary, którą tworzą winiety 4 i 5 . Należy też podkreślić, że nie wystąpiła sytuacja, w której odsetek błędnych uporządkowań przewyższałby odsetek uporządkowań poprawnych. Natomiast znacznie większa jest liczba powiązań, co wynika w pierwszym rzędzie z faktu, że do oceny siedmiu winiet zastosowano 6-punktową skalę, zatem każdy respondent, który udzielił istotnej odpowiedzi na każde z 7 pytań musiał dokonać co najmniej jednego powiązania. Pary winiet, które wydawały się respondentom najbardziej podobne, to przede wszystkim 1 i $2(0,49)$, 4 i $5(0,48)$ oraz w nieco mniejszym stopniu 5 i $6(0,31)$, a także 6 i $7(0,28)$.

Odnotowano 120 różnych wzorów uporządkowań. 10 najczęściej występujących miało następującą postać (numery w klamrach oznaczają winiety, którym przyporządkowano tę samą rangę):

$\{1,2\}, 3,\{4,5\}, 6,7$

$1,2,3,\{4,5,6\}, 7$

$1,2,3,\{4,5\},\{6,7\}$

$1,2,3,\{4,5\}, 6,7$

$\{1,2\}, 3,\{4,5,6\}, 7$

$1,2,\{3,5\},\{4,6\}, 7$

$\{1,2\}, 3,\{4,5\},\{6,7\}$

$\{1,2\}, 3,4,\{5,6\}, 7$

$\{1,2\}, 3,4,5,6,7$

$\{1,2\}, 3,4,5,\{6,7\}$

Dokonując oceny winiet, należy odnotować, że 383 (69,5\%) respondentów „nie naruszyło" porządku ; przypadek wystąpienia 1 błędnego uporządkowania odnotowano u $112(20,3 \%)$ respondentów, 2 takie przypadki u 37 (6,7\%) osób, a 3 lub więcej u 19 (3,4\%) osób. 
Ostatecznie, mimo wystąpienia pewnych zaburzeń, wyniki analiz wskazują, że porządek winiet przyjęty przez badacza odpowiada sposobowi, w jaki winiety porządkuje większość respondentów. Nie ma zatem podstaw do analizowania innych wariantów uszeregowań. Duża zgodność w ocenie winiet przez respondentów pozwala wyprowadzić ostrożny wniosek o spełnieniu założenia VE, z zastrzeżeniem, że sprawdzian nie był rygorystyczny. Gdyby przytoczone tu ustalenia pochodziły z badania pilotażowego, pozwalającego udoskonalić narzędzie do badania właściwego, to można by ewentualnie wysunąć postulat zmniejszenia liczby winiet. W podjęciu takiej decyzji pomocna byłaby analiza mocy dyskryminacyjnej poszczególnych zestawów winiet. Zostanie ona przeprowadzona dalej, gdyż wykorzystuje dane nie tylko odnoszące się do winiet, lecz także do samooceny i po części opiera się na założeniach nieparametrycznej metody korekty błędu.

\subsubsection{Wyniki metody nieparametrycznej}

Z punktu widzenia dalszych analiz ustalenia wymaga teraz zasadnicza kwestia - czy dane są obarczone błędem wynikającym z istnienia różnych standardów oceny? Wystąpienie DIF-u może być sprawdzone na podstawie rozkładów ocen winiet w grupach. W celu utworzenia grup wykorzystano informację o przynależności respondenta do I albo III grupy tercylowej dochodu, w myśl przypuszczenia, że osoby lepiej sytuowane mogą odznaczać się wyższymi standardami oceny sytuacji materialnej niż osoby będące pod tym względem w gorszej sytuacji. Przypuszczenie to znalazło potwierdzenie w danych, co unaocznia tabela 12. oraz wykresy 1-7. Osoby należące do III grupy dochodów gorzej oceniały sytuację materialną „bohaterów" poszczególnych winiet niż osoby z pierwszej - po lewej stronie skal (sytuacja zła) przeważają zwykle oceny respondentów bardziej majętnych, po prawej stronie (sytuacja dobra) - mniej majętnych.

Tabela 12. Rozkład ocen winiet dotyczących sytuacji materialnej wśród osób należących do I oraz III grupy tercylowej dochodu

\begin{tabular}{|c|c|c|c|c|c|c|c|c|c|c|}
\hline Winieta & $\begin{array}{c}\text { Numer } \\
\text { grupy } \\
\text { (tercyl.) }\end{array}$ & $\begin{array}{c}1 . \\
\text { bardzo } \\
\text { zta }\end{array}$ & $\begin{array}{c}2 . \\
\text { zta }\end{array}$ & $\begin{array}{c}3 . \\
\text { raczej } \\
\text { zta }\end{array}$ & $\begin{array}{c}4 . \\
\text { raczej } \\
\text { dobra }\end{array}$ & $\begin{array}{c}5 . \\
\text { dobra }\end{array}$ & $\begin{array}{c}6 . \\
\text { bardzo } \\
\text { dobra }\end{array}$ & $\bar{X}$ & $s$ & $\mathrm{n}$ \\
\hline 1 & 2 & 3 & 4 & 5 & 6 & 7 & 8 & 9 & 10 & 11 \\
\hline \multirow{2}{*}{$1 / \mathrm{e} /$} & 1 & 0,83 & 0,14 & 0,03 & 0,00 & 0,00 & 0,00 & 1,21 & 0,54 & 271 \\
\hline & III & 0,93 & 0,06 & 0,01 & 0,00 & 0,00 & 0,00 & 1,08 & 0,30 & 296 \\
\hline \multirow{2}{*}{$2 / d /$} & 1 & 0,42 & 0,40 & 0,16 & 0,01 & 0,00 & 0,00 & 1,78 & 0,78 & 271 \\
\hline & III & 0,48 & 0,44 & 0,07 & 0,01 & 0,00 & 0,00 & 1,61 & 0,65 & 296 \\
\hline
\end{tabular}




\begin{tabular}{|c|c|c|c|c|c|c|c|c|c|c|}
\hline 1 & 2 & 3 & 4 & 5 & 6 & 7 & 8 & 9 & 10 & 11 \\
\hline \multirow{2}{*}{$3 / c /$} & 1 & 0,03 & 0,20 & 0,50 & 0,22 & 0,04 & 0,01 & 3,05 & 0,88 & 267 \\
\hline & III & 0,05 & 0,29 & 0,55 & 0,09 & 0,02 & 0,00 & 2,74 & 0,76 & 295 \\
\hline \multirow{2}{*}{$4 / b /$} & I & 0,00 & 0,03 & 0,19 & 0,46 & 0,30 & 0,02 & 4,09 & 0,84 & 270 \\
\hline & III & 0,00 & 0,03 & 0,30 & 0,53 & 0,13 & 0,00 & 3,77 & 0,72 & 290 \\
\hline \multirow{2}{*}{$5 / f /$} & 1 & 0,00 & 0,03 & 0,14 & 0,57 & 0,23 & 0,03 & 4,07 & 0,79 & 271 \\
\hline & III & 0,01 & 0,03 & 0,24 & 0,56 & 0,15 & 0,01 & 3,85 & 0,79 & 293 \\
\hline \multirow{2}{*}{$6 / \mathrm{g} /$} & 1 & 0,00 & 0,00 & 0,03 & 0,26 & 0,56 & 0,15 & 4,83 & 0,70 & 271 \\
\hline & III & 0,00 & 0,00 & 0,04 & 0,41 & 0,44 & 0,11 & 4,62 & 0,74 & 295 \\
\hline \multirow{2}{*}{$7 / a /$} & I & 0,00 & 0,00 & 0,00 & 0,07 & 0,21 & 0,72 & 5,65 & 0,60 & 270 \\
\hline & III & 0,00 & 0,00 & 0,00 & 0,08 & 0,34 & 0,58 & 5,49 & 0,65 & 295 \\
\hline
\end{tabular}

Źródło: opracowanie własne - dane nie uwzględniają odpowiedzi trudno powiedzieć.

Winieta 1 (e)

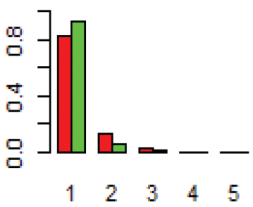

Winieta 4 (b)

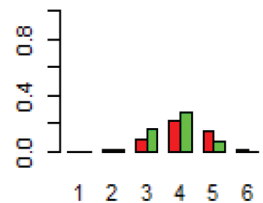

Winieta 2 (d)

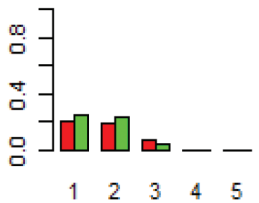

Winieta 5 (f)

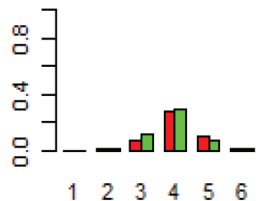

Winieta 3 (c)

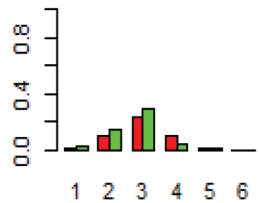

Winieta $6(\mathrm{~g})$

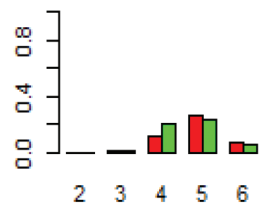

Winieta 7 (a)

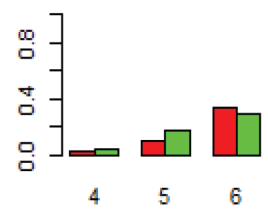

Osoby w I gr. tercylowej dochodów

Osoby w III gr. tercylowej dochodów

Ocena na skali 1-6, gdzie:

1 - bardzo zła

6 - bardzo dobra

Wykresy 1-7. Rozkład ocen winiet dotyczących sytuacji materialnej wśród osób należących do I i III grupy tercylowej dochodu Źródto: opracowanie własne. Wykresy na podstawie danych z tabeli 12. 
Zgodnie z wynikami testu niezależności $c h i^{2}$, w przypadku każdej winiety rozkłady ocen różnią się istotnie wśród osób z I i III grupy tercylowej dochodu.

Także wartości średnich (wykorzystane tu jako miary pomocnicze) pokazują, że osoby z III grupy dochodów konsekwentnie niżej oceniają każdą winietę niż osoby z pierwszej.

Potwierdzenie istnienia zróżnicowanych standardów oceny w dwóch grupach dochodu znajdujemy również w danych ukazujących rozkład samooceny własnej sytuacji materialnej (wykresy 8-9 i tabela 13.).
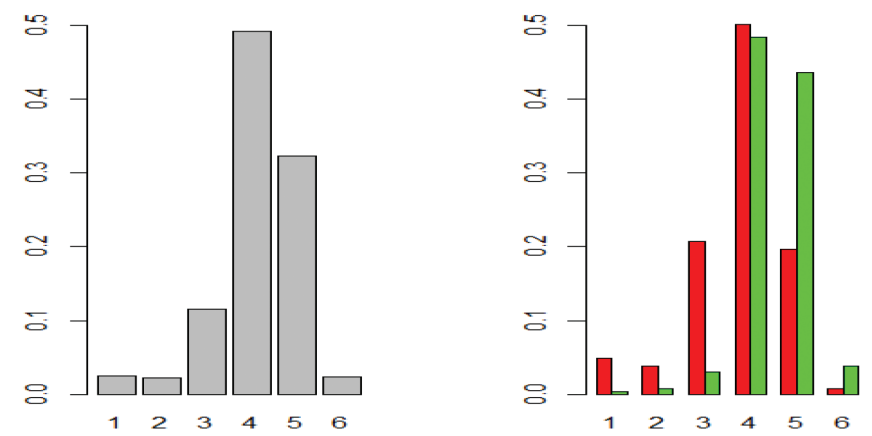

- Osoby z I i III grupy tercylowej dochodów razem

- Osoby z I grupy tercylowej dochodów

- Osoby z III grupy tercylowej dochodów

Ocena na skali 1-6, gdzie: 1 - bardzo zła, 6 - bardzo dobra

Wykresy 8-9. Rozkład odpowiedzi na pytanie o samoocenę własnej sytuacji materialnej

Źródło: opracowanie własne. Wykresy na podstawie danych z tabeli 13.

Tabela 13. Rozkład odpowiedzi na pytanie o samoocenę własnej sytuacji materialnej

\begin{tabular}{|c|c|c|c|c|c|c|c|c|c|}
\hline Zbiór & $\begin{array}{c}1 . \\
\text { bardzo } \\
\text { zła }\end{array}$ & $\begin{array}{l}2 . \\
\text { zta }\end{array}$ & $\begin{array}{c}3 . \\
\text { raczej } \\
\text { zta }\end{array}$ & $\begin{array}{c}4 . \\
\text { raczej } \\
\text { dobra }\end{array}$ & $\begin{array}{c}5 . \\
\text { dobra }\end{array}$ & $\begin{array}{c}6 . \\
\text { bardzo } \\
\text { dobra }\end{array}$ & $\begin{array}{l}\text { Braki } \\
\text { danych }\end{array}$ & $\bar{x}$ & $n$ \\
\hline \multirow{2}{*}{$\begin{array}{l}\text { I i III gr. } \\
\text { tercyl. }\end{array}$} & 14 & 12 & 64 & 275 & 180 & 13 & 10 & & 568 \\
\hline & 0,02 & 0,02 & 0,11 & 0,48 & 0,32 & 0,02 & 0,02 & & 1 \\
\hline \multirow{2}{*}{$\begin{array}{l}\text { I i III gr. } \\
\text { tercyl. } \\
\text { (bez b.d.) }\end{array}$} & 14 & 12 & 64 & 275 & 180 & 13 & - & \multirow{2}{*}{4,14} & 558 \\
\hline & 0,03 & 0,02 & 0,11 & 0,49 & 0,32 & 0,02 & - & & 1 \\
\hline \multirow{2}{*}{$\begin{array}{c}\text { I gr. } \\
\text { (bez b.d.) }\end{array}$} & 13 & 10 & 55 & 133 & 52 & 2 & - & \multirow{2}{*}{3,78} & 265 \\
\hline & 0,05 & 0,04 & 0,21 & 0,50 & 0,20 & 0,01 & - & & 1 \\
\hline \multirow{2}{*}{$\begin{array}{c}\text { III gr. } \\
\text { (bez b.d.) }\end{array}$} & 1 & 2 & 9 & 142 & 128 & 11 & - & \multirow{2}{*}{4,46} & 293 \\
\hline & 0,00 & 0,01 & 0,03 & 0,48 & 0,44 & 0,04 & - & & 1 \\
\hline
\end{tabular}

Źródto: opracowanie własne. 
Rozkład samooceny w I grupie dochodu różni się istotnie statystycznie od rozkładu w III grupie $\left(c h i^{2}(5,558)=86,11, \mathrm{p}<0,01\right)$.

Wyniki na wykresie 8 pokazują przesuniętą na prawo masę prawdopodobieństwa - większość respondentów ocenia swoją sytuację jako raczej dobra (4) lub bardzo dobra (5) - odpowiednio 49\% i 32\% ankietowanych, spośród tych, którzy udzieli istotnej odpowiedzi (średnia 4,13). Wyjaśnienie tej obserwacji można znaleźć na wykresie 9. Podczas, kiedy osoby z III grupy koncentrują się wyraźnie po prawej stronie skali, osoby z I grupy są bardziej zróżnicowane w ocenie własnej sytuacji materialnej, choć zwykle wybierają kategorie środkowe. Jak widać, respondenci będący w obiektywnie różnej sytuacji materialnej często wskazują te same odpowiedzi. Można wziąć dla przykładu odpowiedź nr 5 (dobra) - wybrało ją 20\% ankietowanych o gorszej i 44\% o lepszej sytuacji materialnej. A zatem, skumulowanie się masy prawdopodobieństwa po prawej stronie wykresu wynika $z$ tego, że osoby gorzej uposażone - na skutek niższych standardów oceny - mają tendencję do postrzegania swojej sytuacji jako lepszej.

Rozkłady oceny skorygowanej przedstawiono w tabeli 14 oraz w formie wykresów 10-13. Wyniki opierają się na danych dla osób należących do I i III grupy dochodów, które udzieliły istotnych odpowiedzi na wszystkie siedem pytań z winietami oraz na pytanie o samoocenę. Zbiór ten liczy teraz 532 jednostki (n). Zgodnie z wzorem (1), zmienna $C$ (samoocena skorygowana) przyjmuje 15 wartości.

Tabela 14. Rozkłady samooceny własnej sytuacji materialnej po skorygowaniu metodą nieparametryczną - wyniki dla zestawu 1234567

\begin{tabular}{|c|c|c|c|c|}
\hline C & $\begin{array}{c}\text { Bez obserwacji } \\
\text { wektorowych }\end{array}$ & $\begin{array}{c}\text { Alokacja } \\
\text { równomierna }\end{array}$ & $\begin{array}{c}\text { Alokacja } \\
\text { wg censored } \\
\text { ordered probit }\end{array}$ & $\begin{array}{c}\text { Alokacja przy } \\
\text { minimum entropii }\end{array}$ \\
\hline 1 & 2 & 3 & 4 & 5 \\
\hline 1 & 0,016 & 0,008 & 0,008 & 0,008 \\
\hline 2 & 0,053 & 0,029 & 0,033 & 0,036 \\
\hline 3 & 0,004 & 0,006 & 0,003 & 0,002 \\
\hline 4 & 0,016 & 0,013 & 0,011 & 0,008 \\
\hline 5 & 0,045 & 0,023 & 0,022 & 0,021 \\
\hline 6 & 0,081 & 0,056 & 0,049 & 0,041 \\
\hline 7 & 0,037 & 0,043 & 0,024 & 0,017 \\
\hline 8 & 0,093 & 0,135 & 0,159 & 0,056 \\
\hline 9 & 0,024 & 0,100 & 0,034 & 0,011 \\
\hline 10 & 0,130 & 0,169 & 0,276 & 0,513 \\
\hline 11 & 0,037 & 0,075 & 0,029 & 0,017 \\
\hline
\end{tabular}


Tabela 14 (cd.)

\begin{tabular}{|c|c|c|c|c|}
\hline 1 & 2 & 3 & 4 & 5 \\
\hline 12 & 0,183 & 0,158 & 0,184 & 0,141 \\
\hline 13 & 0,118 & 0,083 & 0,072 & 0,055 \\
\hline 14 & 0,146 & 0,094 & 0,089 & 0,068 \\
\hline 15 & 0,016 & 0,008 & 0,008 & 0,008 \\
\hline $\mathrm{n}$ & 246 & 532 & 532 & 532 \\
\hline
\end{tabular}

Źródto: opracowanie własne

Bez obserwacji wektorowych

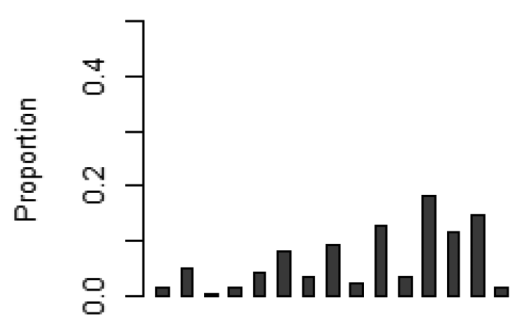

$\begin{array}{lllllll}1 & 3 & 5 & 7 & 9 & 11 & 14\end{array}$

C

Alokacja wg censored ordered probit

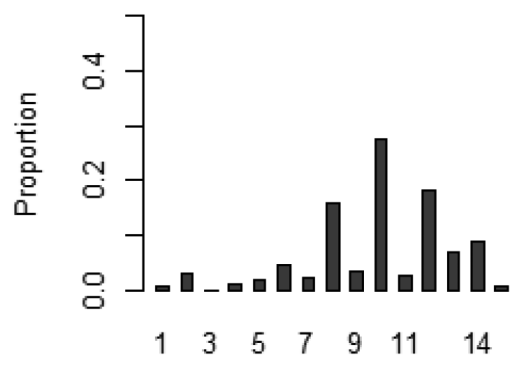

$\mathrm{C}$
Alokacja równomierna

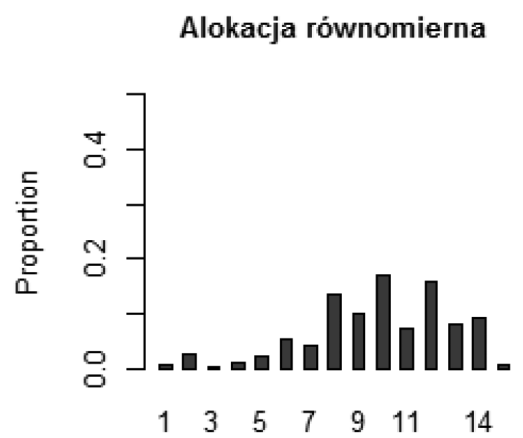

C

Alokacja przy minimum entropii

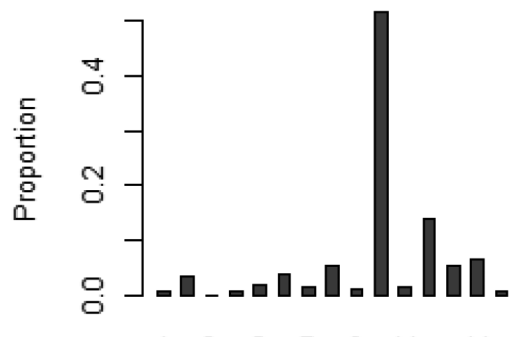

$\begin{array}{lllllll}1 & 3 & 5 & 7 & 9 & 11 & 14\end{array}$

Wykresy 10-13. Rozkłady samooceny własnej sytuacji materialnej po skorygowaniu metodą nieparametryczną - wyniki dla zestawu 1234567

Źródło: opracowanie własne - wykresy na podstawie danych z tabeli 14.

Dla 246 (46,3\%) respondentów możliwe było obliczenie wartości skalarnych, a dla pozostałych $286(53,7 \%)$ wynik przyjmuje postać wektora. Te ostatnie jednostki są rozlokowywane do wartości skalarnych za pomocą trzech różnych me- 
tod $^{3}$ (omówionych dokładniej w poprzednim rozdziale). Wszystkie cztery wykresy dość znacząco się od siebie różnią, co wynika z dużej liczebności zbioru jednostek z wynikiem wektorowym. Porównanie rozkładów samooceny nieskorygowanej (wykresy 8-9) ze skorygowaną (wykresy 10-13) nie jest proste z uwagi na to, że każda ze zmiennych przyjmuje inny zakres wartości. Porównanie kształtów tych rozkładów prowadzi jednak do wniosku o utrzymaniu się lewoskośności.

Obserwacja ta może być wytłumaczona na dwa sposoby. Pierwsze wyjaśnienie mówiłoby, że winiety opisujące niskie poziomy sytuacji materialnej mają za małą moc dyskryminacyjną, tzn. że w badanej populacji występuje bardzo niewiele osób, których sytuacja materialna odpowiada poziomowi winiety 1 (1 /e/) i 2 (2/d/) (brakuje środków na żywność lub na czynsz). Drugie wyjaśnienie podważałoby efektywność samej korekty, upatrując źródła jej niepowodzenia w niespełnieniu założenia o konsekwencji odpowiedzi (RC).

Pierwsze z proponowanych wyjaśnień znalazło potwierdzenie w wynikach analizy mocy dyskryminacyjnej poszczególnych zestawów winiet (razem 127 zestawów o różnej liczbie elementów przy założonym porządku winiet). Wśród zestawów jednoelementowych najniższą wartość entropii odnotowano dla winiety 1. oraz 2. - odpowiednio 0,210 i 0,282, a najwyższą dla winiety 4., wynoszącą 1,062. Wśród zestawów dwuelementowych najbardziej godny polecenia, bo przynoszący najwięcej informacji, jest wariant 46. Ma on najwyższą wartość entropii zarówno wtedy, gdy jest ona obliczona na podstawie przypadków skalarnych (ang. known entropy), jak i wtedy, gdy jest szacowana za pomocą analizy regresji ${ }^{4}$ dla wyników wektorowych - odpowiednio 1,496 oraz 1,565. Najlepszy zestaw trzyelementowy to winiety 346, a najlepszy czteroelementowy to 3467 (najwyższe wartości entropii znanej i szacowanej w poszczególnych zbiorach k-elementowych). Warto też odnotować, że wartość znanej entropii dla zestawu 3467 przewyższała wartość dla pełnego zestawu wyjściowego 1234567, wynosząc odpowiednio 1,782 oraz 1,763. Co oczywiste, mniejszy zestaw generował też mniejszą liczbę przypadków wektorowych. Biorąc pod uwage powyższe informacje, a także koszty związane z dołączeniem każdej następnej winiety do badania, wydaje się, że zestaw 3467 byłby jednym z najbardziej optymalnych rozwiązań.

Powyższe informacje ważne są także z punktu widzenia analiz mających stanowić podstawę drugiego wyjaśnienia. Analizy te są nastawione na sprawdzenie poprawności założenia RC poprzez porównanie rozkładów oceny skorygowanej w podgrupach wyróżnionych ze względu na zmienną mówiącą o tym, do jakiej grupy dochodów należy respondent. W trakcie ich prowadzenia okazało się, że ze względu na układ danych $\mathrm{i} /$ lub zmienne ${ }^{5}$ użyte $\mathrm{w}$ analizie regresji nie

3 W analizie regresji (ang. censored ordered probit) wykorzystano następujące zmienne niezależne: płeć ( $\mathrm{K}=1, \mathrm{M}=0)$; czy R należy do I grupy dochodów (tak = 1, nie = 0); wykształcenie (wyższe $=1$, pozostałe $=0$ ), wiek.

4 Jak wyżej.

5 Wykorzystano następujące zmienne niezależne: płeć $(K=1, M=0)$; wykształcenie (wyższe $=1$, pozostate $=0$ ) i wiek. 
można przewidzieć niektórych wartości 15-punktowej skali C. Poszukiwano więc zmniejszonego zestawu winiet, który taką predykcję umożliwi przy zredukowanym zakresie wartości zmiennej $C$. Wymagania te spełnił dopiero zestaw trzyelementowy o największej mocy dyskryminacyjnej (346).

Dla zachowania porządku wywodu, analiza danych wykorzystujących zestaw 346 rozpocznie się od podania informacji o rozkładach samooceny skorygowanej w całym zbiorze (osoby z I i III grupy dochodów razem). Wyniki przedstawiono w tabeli 15 i na wykresach 14-18, które dodatkowo dają możliwość porównania rozkładów samooceny przed korektą i po niej.

Tabela 15. Rozkłady samooceny własnej sytuacji materialnej po skorygowaniu metodą nieparametryczną - wyniki dla zestawu 346

\begin{tabular}{|c|c|c|c|c|}
\hline $\mathbf{C}$ & $\begin{array}{c}\text { Bez obserwacji } \\
\text { wektorowych }\end{array}$ & $\begin{array}{c}\text { Alokacja } \\
\text { równomierna }\end{array}$ & $\begin{array}{c}\text { Alokacja wg censored } \\
\text { ordered probit }\end{array}$ & $\begin{array}{c}\text { Alokacja przy mi- } \\
\text { nimum entropii }\end{array}$ \\
\hline 1 & 0,097 & 0,078 & 0,077 & 0,076 \\
\hline 2 & 0,088 & 0,084 & 0,078 & 0,069 \\
\hline 3 & 0,047 & 0,059 & 0,045 & 0,037 \\
\hline 4 & 0,216 & 0,232 & 0,262 & 0,196 \\
\hline 5 & 0,123 & 0,152 & 0,133 & 0,097 \\
\hline 6 & 0,261 & 0,260 & 0,271 & 0,392 \\
\hline 7 & 0,168 & 0,136 & 0,135 & 0,132 \\
\hline$n$ & 422 & 536 & 536 & 536 \\
\hline
\end{tabular}

Źródło: opracowanie własne.

Obserwacja wykresów 14-18 prowadzi do spostrzeżenia, że rozkłady mniej się różnią między sobą niż miało to miejsce w przypadku rozkładów na wykresach 10-13. Nie jest to trudne do wyjaśnienia - zestaw 1234567 wygenerował tylko $246(46,3 \%)$ wartości skalarnych, podczas gdy zestaw 346 aż $422(63,2 \%)$ i dlatego ten ostatni jest bardziej odporny na działanie algorytmów zaimplementowanych w poszczególnych metodach rozlokowujących wartości wektorowe. Jednak spostrzeżeniem ważniejszym z punktu widzenia celu analizy jest utrzymanie się większej masy prawdopodobieństwa po prawej stronie skali, mimo wyeliminowania winiet 1. i 2., które „niepotrzebnie” wydłużały lewe ramię rozkładu. Z drugiej jednak strony - porównując rozkład wyjściowy (oceny nieskorygowanej) z efektami korekty - należy zauważyć pewną poprawę, polegającą na przesunięciu części masy prawdopodobieństwa na lewą stronę skali. 
Samoocena nieskoryg.

Bez obserwacji wektorowych

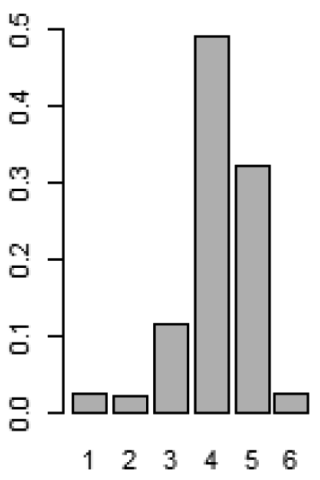

Alokacja wg censored ordered probi

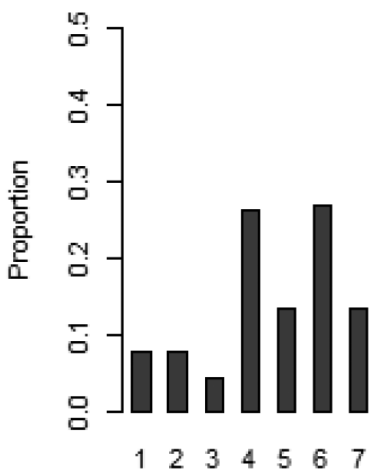

C

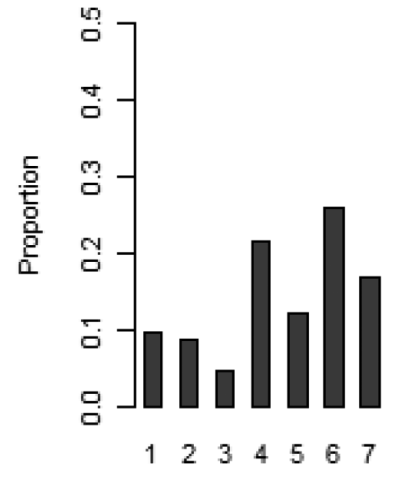

C Alokacja przy minimum entropii

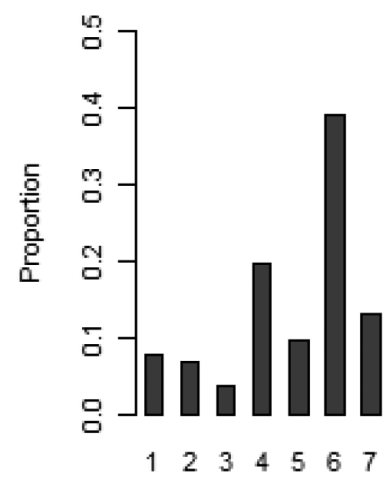

C

Wykresy 14-18. Rozkład samooceny własnej sytuacji materialnej przed korektą oraz po skorygowaniu metodą nieparametryczną - wyniki dla zestawu 346 Źródto: opracowanie własne - wykresy 16-19 na podstawie danych z tabeli 15.

Analiza danych pozwalających prześledzić, jak odpowiadały osoby z I, a jak osoby z III grupy dochodów przybliża do poznania istoty problemu (tabela 16 i wykresy 19-22). Jego źródłem wydają się osoby należące do I grupy. Jedna ich część, zgodnie z oczekiwaniem stawianym przed metodą, została „przesunięta” na lewo, a więc na miejsca odnoszące się do gorszej sytuacji materialnej, natomiast druga - i liczebnie znaczna - lokuje się na pozycjach świadczących o lepszej sytuacji materialnej. 
Tabela 16. Rozkłady samooceny własnej sytuacji materialnej po skorygowaniu metodą nieparametryczną dla osób należących do I oraz III grupy dochodów - wyniki dla zestawu 346

\begin{tabular}{|c|c|c|c|c|c|c|c|c|}
\hline \multirow{2}{*}{ C } & \multicolumn{2}{|c|}{$\begin{array}{c}\text { Bez obserwacji } \\
\text { wektorowych }\end{array}$} & \multicolumn{2}{c|}{$\begin{array}{c}\text { Alokacja } \\
\text { równomierna }\end{array}$} & \multicolumn{2}{c|}{$\begin{array}{c}\text { Alokacja } \\
\text { wg censored } \\
\text { ordered probit }\end{array}$} & \multicolumn{2}{c|}{$\begin{array}{c}\text { Alokacja } \\
\text { przy minimum } \\
\text { entropii }\end{array}$} \\
\cline { 2 - 10 } & I gr. & III gr. & I gr. & III gr. & I gr. & III gr. & I gr. & III gr. \\
\hline 1 & 0,194 & 0,017 & 0,146 & 0,015 & 0,146 & 0,014 & 0,145 & 0,014 \\
\hline 2 & 0,168 & 0,022 & 0,146 & 0,027 & 0,141 & 0,020 & 0,125 & 0,018 \\
\hline 3 & 0,073 & 0,026 & 0,086 & 0,033 & 0,067 & 0,024 & 0,055 & 0,021 \\
\hline 4 & 0,225 & 0,208 & 0,242 & 0,224 & 0,288 & 0,235 & 0,422 & 0,186 \\
\hline 5 & 0,105 & 0,139 & 0,140 & 0,163 & 0,119 & 0,147 & 0,078 & 0,114 \\
\hline 6 & 0,162 & 0,342 & 0,182 & 0,330 & 0,183 & 0,353 & 0,121 & 0,443 \\
\hline 7 & 0,073 & 0,247 & 0,058 & 0,207 & 0,056 & 0,207 & 0,055 & 0,204 \\
\hline $\mathrm{n}$ & 191 & 231 & 256 & 280 & 256 & 280 & 256 & 280 \\
\hline
\end{tabular}

Źródto: opracowanie własne.

Bez obserwacji wektorowych

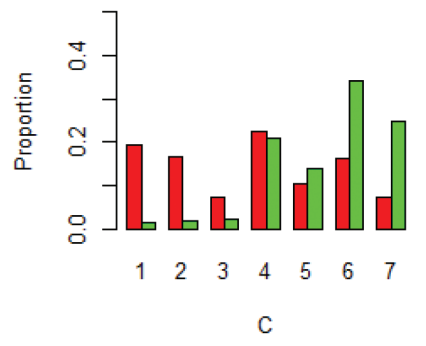

Alokacja wg censored ordered probit

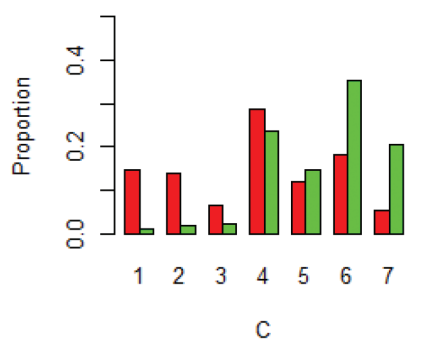

Alokacja równomierna

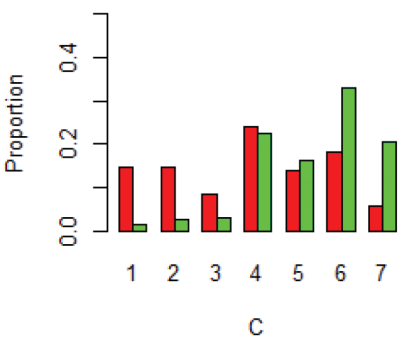

Alokacja przy minimum entropii

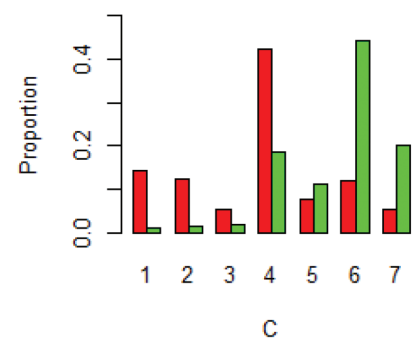

Wykresy 19-22. Rozkłady samooceny własnej sytuacji materialnej po skorygowaniu metodą nieparametryczną dla osób należących do I oraz III grupy dochodów - wyniki dla zestawu 346

Źródło: opracowanie własne - wykresy na podstawie danych z tabeli 16. 
Omawianą prawidłowość dokładniej ilustrują wykresy 23 i 24. Jeżeli przywołać treść użytych winiet, to okazałoby się, że blisko $24 \%$ respondentów deklarujących dochód miesięczny na osobę w wysokości 100-900 zł (I grupa) uzyskało rangę 6 lub 7, które odpowiadają poziomowi bezpieczeństwa czy nawet swobody finansowej. Nawet pobieżna orientacja w zakresie siły nabywczej pieniądza w Polsce w okresie odpowiadającym realizacji badania sugeruje ocenę tego zestawienia jako nieprzystającego do rzeczywistości.

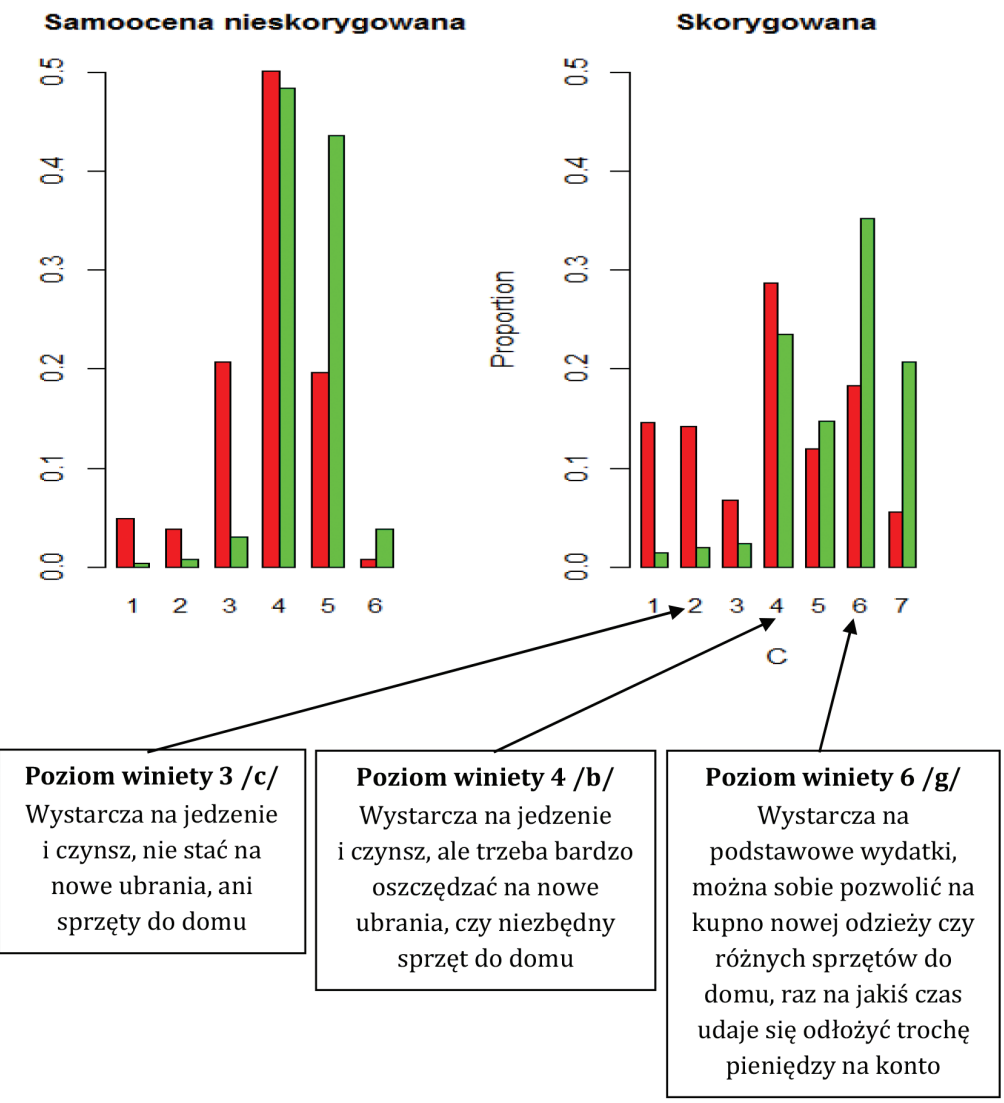

Wykresy 23-24. Rozkład samooceny własnej sytuacji materialnej przed korektą i po skorygowaniu metodą nieparametryczną (wg censored ordered probit) dla zestawu 346 wśród osób należących do I oraz III grupy tercylowej dochodów

Źródto: opracowanie własne.

$\mathrm{W}$ interpretacji można zaproponować przypuszczenie, że w przypadku tych respondentów nie zostało spełnione założenie o konsekwencji odpowiedzi (RC), tzn. że przyłożyli oni inne standardy w ocenie siebie i inne w ocenie winiet. Pytanie okazało się najprawdopodobniej drażliwe i zagrażające, dlatego w celu ochrony dobrego mniemania o sobie lub $\mathrm{z}$ chęci pokazania się $\mathrm{w}$ dobrym świetle przed ankieterem zawyżono ocenę własnej sytuacji materialnej. Konkurencyjne wyjaśnienie mówiłoby, że dekla- 
racje dotyczące dochodu tych osób zostały przez nich zaniżone, ale wydaje się ono znacznie mniej prawdopodobne. Dostarczając wsparcia dla tej argumentacji, można wskazać, że wartości materialne są w polskiej kulturze wysoko waloryzowane ${ }^{6}$, obserwuje się także proces bogacenia się społeczeństwa (Czapiński, Panek 2011) - zjawiska te wytwarzają klimat sprzyjający presji w kierunku osiągania odpowiednio wysokiej pozycji materialnej oraz bycia postrzeganym jako osoba, która taką pozycję osiągnęła.

Dla empirycznego ugruntowania tej hipotezy można odwołać się do danych i prześledzić sposób odpowiadania osób, które, należąc do I grupy tercylowej dochodów, osiągnęły poziom 6. i 7. na skali C. Jednym z ograniczeń wniosków takiej analizy jest fakt, że można ją przeprowadzić jedynie w odniesieniu do jednostek, które na skali C uzyskały wartość nie będącą wektorem, niemniej zgodnie z tabelą 16., a także wykresem 19 i 21, rozkład samooceny skorygowanej w wariancie „Alokacja wg censored ordered probit” nie odbiega znacząco od rozkładu dla „Bez obserwacji wektorowych”. Jeszcze inne ograniczenie, ale wiążące się z poprzednim, polega na tym, że nie jest to zbiór zbyt liczny $(\mathrm{n}=45)$. Jak pokazują wyniki, w grupie tej zdecydowaną większoość (73\%) stanowią osoby, które poproszone o ocenę sytuacji materialnej we własnym gospodarstwie domowym odpowiedziały, że jest ona dobra bądź bardzo dobra. Można dodać, że odpowiedzi dla winiet wskazują na posiadanie raczej niskich standardów oceny, ma to już jednak mniejsze znaczenie, ponieważ skrajne wartości samooceny bardziej „unieruchamiają” wynik na skali C niż wartości środkowe - sposób oceny winiet ma większe znaczenie i potrafi znacząco zmienić pozycję respondenta na skali C wtedy, gdy samoocena nie przyjęła skrajnych wartości (niskich bądź wysokich)7.

Z kolei porównanie wykresów 23 i 24 pod kątem rozkładów dla osób z III grupy dochodów skłaniałoby do wniosku o efektywnie dokonanej korekcie. W przypadku samooceny nieskorygowanej osoby te były skupione w kategoriach 4. i 5. (raczej dobra i dobra). Rozkład był mało zróżnicowany, co nie współgrało do końca z dużą rozpiętością dochodów w tej grupie (1,5 tys. -8 tys. zł). Korekta dokonana w oparciu o winiety niuansuje te przypadki, rozkładając bardziej równomiernie masę prawdopodobieństwa w zakresie punktów 4-7 na skali C - rozmieszcza w ten sposób różne osoby począwszy od tych, których sytuacja materialna odpowiada poziomowi „[...] trzeba oszczędzać na nowe ubrania i niezbędny sprzęt do domu" (poziom winiety 4 /b/), aż po osoby posiadające nadwyżki finansowe pozwalające nie tylko na swobodę w zakresie zakupu nowej odzieży, czy sprzętów do domu, ale mające też większe możliwości, jeśli chodzi o gromadzenie oszczędności (poziom powyżej winiety $6 / \mathrm{g} /$ ).

6 Na podstawie wyników sondażu European Values Study wiadomo, że dobre zarobki były wskazywane jako cecha ważna w pracy przez 79,6\% Polaków w 1990 r. i 93,8\% w 2008 r. (Marody 2012: 70). W edycji EVS z 2008 r. za ważne dla udanego małżeństwa 87,3\% Polaków uznało odpowiedni dochód, a 93,4\% dobre warunki mieszkaniowe (suma odpowiedzi bardzo ważne i raczej ważne) (Jasińska-Kania i in. 2012: 355).

7 Oczywiście nie jest to jedyny układ odpowiedzi, który prowadzi do osiągnięcia poziomu 6 i 7 na skali C, np. jeżeli winietę 6 /g/ respondent oceniłby dość nisko (raczej zła, raczej dobra), czyli w sposób odpowiadający podwyższonym standardom oceny, a siebie na tym samym poziomie bądź wyżej, to również osiągnąłby jeden z tych wysokich wyników. 


\subsubsection{Wyniki metody parametrycznej}

Tabela 17 - jako rezultat wykorzystania metody parametrycznej - stanowi ilustrację oszacowanych parametrów kilku modeli analizy regresji. Znajdują się w niej szacunki nie tylko dla modeli CHOPIT (w odniesieniu do dwóch branych wcześniej pod uwagę zestawów winiet: 1234567 oraz 346), ale także dla modelu ordered probit, który jako niekorygujący błędu jest modelem „bazowym” i pełni rolę punktu odniesienia.

Przed porównaniem modeli, warto zwrócić wcześniej uwagę na wartości parametrów theta. Świadczą one o tym, że uporządkowanie winiet w kolejności 1234567 (w tym też 346) jest prawidłowe - taki układ stanowi rosnące kontinuum. Jest to parametryczny test na potwierdzenie spełnienia założenia VE.

Różnice w oszacowaniach obydwu modeli CHOPIT są niewielkie, dlatego to model z większą liczbą winiet (1234567), jako pełniejszy, będzie przedmiotem porównania z modelem ordered probit. Pierwsza obserwacja jest taka, że znaki przy współczynnikach beta nie różnią się między modelami, a zatem jest zgodność w ocenach w odniesieniu do kierunku oddziaływania poszczególnych zmiennych. Jak widać, nie tylko model CHOPIT trafnie wskazuje na osoby z I grupy dochodów jako odznaczające się niższym poziomem sytuacji materialnej, ale także model „bazowy”. W zrozumieniu otrzymanego rezultatu być może przydatna będzie pewne wyjaśnienie. W niektórych badaniach, dobrym przykładem będzie tu wspominane już studium Kinga i Wanda nad poczuciem wpływu na rządzących wśród mieszkańców Chin i Meksyku, obserwuje się dość spektakularne różnice w oszacowaniach modeli, objawiające się już na poziomie znaków przy współczynniku beta. Dlaczego tu, pomimo stwierdzenia DIF, nie zaobserwowano takiego efektu? Odpowiedź jest następująca - zmiana znaku charakterystyczna będzie dla takiego układu wyników, w którym rozbieżności w standardach oceny są tak duże, że wartości centralne samoocen wprowadzają w błąd co do tego, która grupa odznacza się wyższym, a która niższym poziomem cechy (obniżone standardy oceny u Chińczyków i odpowiednio do nich wysokie wartości samooceny spowodowały, że w zestawieniu z Meksykanami zdawali się prezentować wyższy poziom poczucia wpływu na rządzących). W analizowanym przypadku taki układ wyników nie wystąpił - wprawdzie obserwuje się występowanie międzygrupowego DIF między osobami z I i III grupy dochodów, ale nie jest on na tyle duży, aby samooceny wywołały wrażenie, że to biedniejsza grupa jest w istocie bardziej majętna (zob. wykresy 8-9 i średnie w tabeli 6). Z tego względu także model ordered probit, który nie ma zdolności korygowania błędu, dał trafne co do znaku oszacowanie. W konsekwencji korekty - wyrażającej się niższą wartością parametru beta w modelu CHOPIT $(-1,22)$ niż porządkowym probit $(-0,816)$ - możemy powiedzieć, że sytuacja materialna osób z I grupy, w porównaniu z sytuacją osób z III grupy, jest na niższym poziomie niż wskazywały na to samooceny.

Podobnie, pozostałe wyniki regresji potwierdzają wnioski wyprowadzone na drodze analiz nieparametrycznych. I tak, przejdźmy do omówienia współczynników gamma, które pozwalają przewidywać wartości kolejnych progów. Przykła- 
dowo, wartość gamma dla progu między zdecydowanie zła a zła (pierwszy próg) wynosząca $-0,11$ oznacza, że osoby z I grupy są bardziej skłonne oceniać ten sam (niski) poziom sytuacji materialnej jako $z \nmid y$ niż zdecydowanie $z \nmid y$ w porównaniu z osobami z III grupy. Takie prawidłowości obserwuje się w odniesieniu do niemal wszystkich progów, chociaż wartości współczynników sugerują, że są to efekty bardzo małe i nie zawsze istotne statystycznie.

Tabela 17. Oszacowania regresji dla modelu porządkowego probit oraz modeli CHOPIT

\begin{tabular}{|c|c|c|c|c|c|c|}
\hline \multirow[t]{2}{*}{ Wyszczególnienie } & \multicolumn{2}{|c|}{ Model ordered probit } & \multicolumn{2}{|c|}{$\begin{array}{l}\text { Model CHOPIT } \\
\text { (zestaw winiet: } \\
1234567 \text { ) }\end{array}$} & \multicolumn{2}{|c|}{$\begin{array}{c}\text { Model CHOPIT } \\
\text { (zestaw winiet: } 346)\end{array}$} \\
\hline & wartość & $\begin{array}{l}\text { błąd } \\
\text { stan. }\end{array}$ & wartość & $\begin{array}{l}\text { błąd } \\
\text { stan. }\end{array}$ & wartość & $\begin{array}{l}\text { błąd } \\
\text { stan. }\end{array}$ \\
\hline 1 & 2 & 3 & 4 & 5 & 6 & 7 \\
\hline \multicolumn{7}{|c|}{ Zmienne wyjaśniajace $(\beta)$} \\
\hline Płeć (kobieta) & $-0,048$ & 0,093 & $-0,112$ & 0,102 & $-0,094$ & 0,109 \\
\hline Wiek & $-0,017^{\star \star}$ & 0,004 & $-0,021^{\star \star}$ & 0,005 & $-0,023^{\star \star}$ & 0,005 \\
\hline $\begin{array}{l}\text { Wykształcenie } \\
\text { (wyższe) }\end{array}$ & $0,244^{*}$ & 0,113 & $0,318^{*}$ & 0,126 & $0,363^{\star *}$ & 0,136 \\
\hline $\begin{array}{l}\text { Dochody } \\
\text { (I gr. tercylowa) }\end{array}$ & $-0,816^{\star \star}$ & 0,104 & $-1,220^{\star \star}$ & 0,119 & $-1,259^{\star \star}$ & 0,127 \\
\hline \multicolumn{7}{|l|}{ Próg $1(\gamma 1)$} \\
\hline Płeć (kobieta) & & & $-0,055$ & 0,071 & $-0,049$ & 0,135 \\
\hline Wiek & & & $-0,002$ & 0,003 & $-0,007$ & 0,006 \\
\hline $\begin{array}{l}\text { Wykształcenie } \\
\text { (wyższe) }\end{array}$ & & & 0,032 & 0,085 & 0,022 & 0,166 \\
\hline $\begin{array}{l}\text { Dochody } \\
\text { (I gr. tercylowa) }\end{array}$ & & & $-0,110$ & 0,076 & 0,278 & 0,170 \\
\hline Stała & $-4,151$ & 0,263 & $-4,465$ & 0,327 & $-4,524$ & 0,404 \\
\hline \multicolumn{7}{|l|}{ Próg $2(\gamma 2)$} \\
\hline Płeć (kobieta) & & & $-0,058$ & 0,078 & $-0,055$ & 0,130 \\
\hline Wiek & & & 0,002 & 0,003 & 0,009 & 0,005 \\
\hline $\begin{array}{l}\text { Wykształcenie } \\
\text { (wyższe) }\end{array}$ & & & 0,067 & 0,091 & 0,023 & 0,150 \\
\hline $\begin{array}{l}\text { Dochody } \\
\text { (I gr. tercylowa) }\end{array}$ & & & $-0,108$ & 0,085 & $-0,452^{\star \star}$ & 0,169 \\
\hline Stała & 0,030 & 0,054 & $-0,003$ & 0,170 & $-0,217$ & 0,263 \\
\hline
\end{tabular}




\begin{tabular}{|c|c|c|c|c|c|c|}
\hline 1 & 2 & 3 & 4 & 5 & 6 & 7 \\
\hline \multicolumn{7}{|l|}{ Próg $3(\gamma 3)$} \\
\hline Płeć (kobieta) & & & $-0,011$ & 0,062 & $-0,022$ & 0,075 \\
\hline Wiek & & & 0,001 & 0,003 & $-0,001$ & 0,003 \\
\hline $\begin{array}{l}\text { Wykształcenie } \\
\text { (wyższe) }\end{array}$ & & & $-0,092$ & 0,076 & 0,023 & 0,088 \\
\hline $\begin{array}{l}\text { Dochody } \\
\text { (I gr. tercylowa) }\end{array}$ & & & $-0,119$ & 0,066 & $-0,162^{\star \star}$ & 0,082 \\
\hline Stała & 0,145 & 0,047 & 0,200 & 0,141 & 0,362 & 0,166 \\
\hline \multicolumn{7}{|l|}{ Próg $4(\gamma 4)$} \\
\hline Płeć (kobieta) & & & 0,075 & 0,047 & 0,078 & 0,057 \\
\hline Wiek & & & $-0,006^{\star *}$ & 0,002 & $-0,007^{\star}$ & 0,003 \\
\hline $\begin{array}{l}\text { Wykształcenie } \\
\text { (wyższe) }\end{array}$ & & & 0,039 & 0,055 & 0,001 & 0,068 \\
\hline $\begin{array}{l}\text { Dochody } \\
\text { (I gr. tercylowa) }\end{array}$ & & & $-0,064$ & 0,050 & $-0,140^{\star}$ & 0,061 \\
\hline Stała & 0,321 & 0,039 & 0,592 & 0,109 & 0,632 & 0,131 \\
\hline \multicolumn{7}{|l|}{ Próg $5(\gamma 5)$} \\
\hline Płeć (kobieta) & & & 0,005 & 0,058 & 0,093 & 0,074 \\
\hline Wiek & & & $-0,002$ & 0,003 & 0,000 & 0,003 \\
\hline $\begin{array}{l}\text { Wyksztatcenie } \\
\text { (wyższe) }\end{array}$ & & & 0,114 & 0,067 & 0,129 & 0,089 \\
\hline $\begin{array}{l}\text { Dochody } \\
\text { (I gr. tercylowa) }\end{array}$ & & & 0,058 & 0,061 & 0,094 & 0,082 \\
\hline Stała & 0,280 & 0,045 & 0,315 & 0,130 & 0,295 & 0,166 \\
\hline \multicolumn{7}{|l|}{ Winiety } \\
\hline$\theta_{1}-$ winieta $1 / \mathrm{e} /$ & & & $-5,755$ & 0,326 & & \\
\hline$\theta_{2}-$ winieta $2 / d /$ & & & $-4,570$ & 0,296 & & \\
\hline$\theta_{3}-$ winieta $3 / c /$ & & & $-3,108$ & 0,269 & $-3,245$ & 0,288 \\
\hline$\theta_{4}-$ winieta $4 / \mathrm{b} /$ & & & $-1,799$ & 0,253 & $-1,903$ & 0,271 \\
\hline$\theta_{5}-$ winieta $5 / \mathfrak{f} /$ & & & $-1,748$ & 0,253 & & \\
\hline$\theta_{6}-$ winieta $6 / \mathrm{g} /$ & & & $-0,699$ & 0,246 & $-0,753$ & 0,262 \\
\hline$\theta_{7}-$ winieta $7 / a /$ & & & 0,668 & 0,247 & & \\
\hline $\ln (\sigma)$ & & & $-0,038$ & 0,039 & $-0,029$ & 0,043 \\
\hline Log likelihood & \multicolumn{2}{|c|}{-4629.16} & \multicolumn{2}{|c|}{$-4468,639$} & \multicolumn{2}{|c|}{$-2543,030$} \\
\hline
\end{tabular}

*Współczynnik istotny na poziomie $p<0,05$; ${ }^{* \star}$ współczynnik istotny na poziomie $p<0,01$. Źródto: opracowanie własne. 
Pozostałe zmienne w modelu nie są silnie związane z poziomem sytuacji materialnej (niskie wartości beta) - jedynie w przypadku wykształcenia obserwujemy silniejszy związek taki, że „wyższe” zwiększa prawdopodobieństwo jej polepszenia się. Jednak ani ta zmienna, ani pozostałe w modelu - oprócz zmiennej, która mówi czy respondent znajduje się w I grupie dochodów - nie wyjaśniają DIF. To pomyślna informacja, w przeciwnym bowiem przypadku zmienne te mogłyby by być odpowiedzialne za wywołanie DIF-u wewnątrz grup. Jak piszą King i in. (2004: 203), problem ten można poddać badaniu, kontrolując wybrane zmienne i sprawdzając czy w wyniku tej operacji nie spada wartość współczynnika dla zmiennej, którą wytypowaliśmy jako wywołującą DIF między grupami. Opisana sytuacja w tym przypadku nie zachodzi, przynajmniej w odniesieniu do zmiennych uwzględnionych w modelu. Przy wyłączeniu wykształcenia $\mathrm{z}$ równania (z komponentu dla winiet), wartość beta dla I grupy dochodu utrzymuje się na poziomie $(-1,242)$. Podobny wynik $(-1,244)$ uzyskuje się, jeżeli w równaniu zostanie jedynie zmienna „I grupa tercylowa dochodu”.

$\mathrm{Na}$ koniec należy jeszcze wrócić do obserwacji poczynionych w trakcie analizy prowadzonej metodą nieparametryczną, które sugerują, że samooceny, oprócz międzygrupowego DIF, są dodatkowo zniekształcone przez błąd społecznej poprawności. Wyjaśnienie takie zaproponowano po stwierdzeniu, że część respondentów z I grupy dochodów osiągnęła zbyt wysoką, jak na zadeklarowaną wysokość dochodów, pozycję na skali C. Ustalono, że w zdecydowanej większości przypadków tę „anomalię" wywołała samoocena mówiąca, że sytuacja w gospodarstwie domowym jest dobra albo bardzo dobra, co można rozumieć jako chęć pokazania się w korzystnym świetle. Jeżeli więc słuszny jest ten ostrożny wniosek o niespełnieniu założenia konsekwencji odpowiedzi, wyniki osiągnięte metodą parametryczną także nie mogą być przyjęte bez uwag. Zastrzeżenie mówi o niedoszacowaniu współczynnika beta, a zatem różnica w sytuacji materialnej osób z I i III grupy dochodu jest nie tylko większa od tej, jaką wskazują samooceny, ale także większa od tej, jaką wskazują szacunki modelu CHOPIT.

\subsection{Wyniki badania potrzeby doskonalenia własnych kwalifikacji zawodowych}

Tworząc wskaźnik potrzeby doskonalenia własnych kwalifikacji zawodowych, niezależnej miary służącej do weryfikacji założenia RC, wykorzystano kilka pytań kwestionariusza. Pierwszą grupę stanowiły pytania badające chęć podjęcia kształcenia $\mathrm{w}$ przyszłości - czy respondent jest zainteresowany kontynuowaniem nauki w formie 
szkolnej (kształceniem formalnym ${ }^{8}$ ) oraz czy jest zainteresowany odbyciem szkoleń i kursów ${ }^{9}$ (w tym wypadku wzięto pod uwagę tylko odpowiedzi zdecydowanie tak ${ }^{10}$ ).

Druga grupa pytań odnosiła się do przeszłości i badała historię dotychczas odbytych przez respondenta kursów. Mając na względzie, że część takich szkoleń musiała zostać odbyta w sposób obligatoryjny (np. szkolenia BHP), co nie musi świadczyć o istnieniu potrzeby dokształcania, przy konstrukcji wskaźnika wzięto pod uwagę tylko te szkolenia, co do których respondent zadeklarował, że wyszedł z inicjatywą ich odbycia ${ }^{11}$ lub pokrył, chociażby częściowo, ich koszty ${ }^{12}$.

8 Pytanie brzmiało: Proszę spojrzeć na tę kartę [ANKIETER: wręcz kartę] i powiedzieć, czy byt(a)by P. zainteresowany w przyszłości wymienionymi formami kształcenia. Proszę wskazać wszystkie szkoły, uczęszczanie do których P. rozważa.

1) Zasadnicza szkoła zawodowa dla dorosłych,

2) Liceum ogólnokształcące dla dorosłych,

3) Liceum profilowane dla dorostych,

4) Technikum dla dorosłych,

5) Szkoła policealna / pomaturalna dla dorosłych,

6) Szkoła wyższa - studia pierwszego stopnia (trzyletnie - licencjackie / inżynierskie),

7) Szkoła wyższa - studia drugiego stopnia (dwuletnie - magisterskie),

8) Szkoła wyższa - jednolite studia magisterskie / lekarskie (pięcio- / sześcioletnie),

9) Szkoła wyższa - studia podyplomowe,

10) Szkoła wyższa - studia doktoranckie,

11) Szkoła wyższa - niesprecyzowany rodzaj studiów,

12) R. nie jest zainteresowany żadna z wymienionych form kształcenia,

13) Trudno powiedzieć.

9 Pytanie brzmiało: Niezależnie od tego, czy zamierza się P. ksztatcić w jakiejś szkole, czy też nie, czy był(a)by P. zainteresowany(a) odbyciem w przyszłości jakichś szkoleń lub kursów?

1) Zdecydowanie tak,

2) Raczej tak,

3) Raczej nie,

4) Zdecydowanie nie,

5) Trudno powiedzieć.

10 35,3\% udzielito odpowiedzi zdecydowanie tak oraz 37,1\% raczej tak. Łączny udział zainteresowanych wynosił więc $72,4 \%$ i, jak się wydaje, był zbyt wysoki, aby deklaracje te można było potraktować jako trafny predyktor przyszłych zachowań.

11 Pytanie brzmiało: Kto wyszedł z pomysłem zgłoszenia P. do udziału w tym szkoleniu? [ANKIETER: wręcz kartę]

1) P. $\operatorname{sam}(a)$

2) P. pracodawca - udział w szkoleniu był dla P. obowiązkowy

3) P. pracodawca - mó(o)gł(a) P. się nie zgodzić na udział w szkoleniu

4) Urząd Pracy, w którym był(a) P. zarejestrowany(a)?

5) Inna sytuacja

6) R. nie pamięta

12 Pytanie brzmiało: Kto sfinansowat P. udział w tym szkoleniu?

1) P. $\operatorname{sam}(a)$

2) P. pracodawca

3) P. oraz P. pracodawca

4) Udział w szkoleniu był bezpłatny / finansowany ze środków zewnętrznych (np. unijnych)

5) R. nie pamięta. 
Sposób budowy wskaźnika po dokonaniu transformacji wyjściowych zmiennych przybliża tabela 18 . Pokazuje ona łączny rozkład dwóch nowo utworzonych zmiennych, stanowiący podstawę rozważań o docelowej postaci wskaźnika. Jak pisano wyżej, łącznie rozpatrzono trzy rodzaje deklaracji: 1) chęć odbycia kursów, 2) chęć kontynuacji kształcenia formalnego, 3) odbycie przynajmniej jednego szkolenia, które było inicjowane lub (współ)finansowane przez respondenta. Za osoby przejawiające potrzebę doskonalenia własnych kwalifikacji zawodowych ostatecznie uznano te, u których odnotowano przynajmniej jeden taki rodzaj deklaracji na trzy możliwe (odpowiadają im pola zaznaczone na zielono w tabeli). Procent takich osób w próbie wyniósł 64,9.

Tabela 18. Konstrukcja i rozkład wskaźnika potrzeby doskonalenia własnych kwalifikacji zawodowych

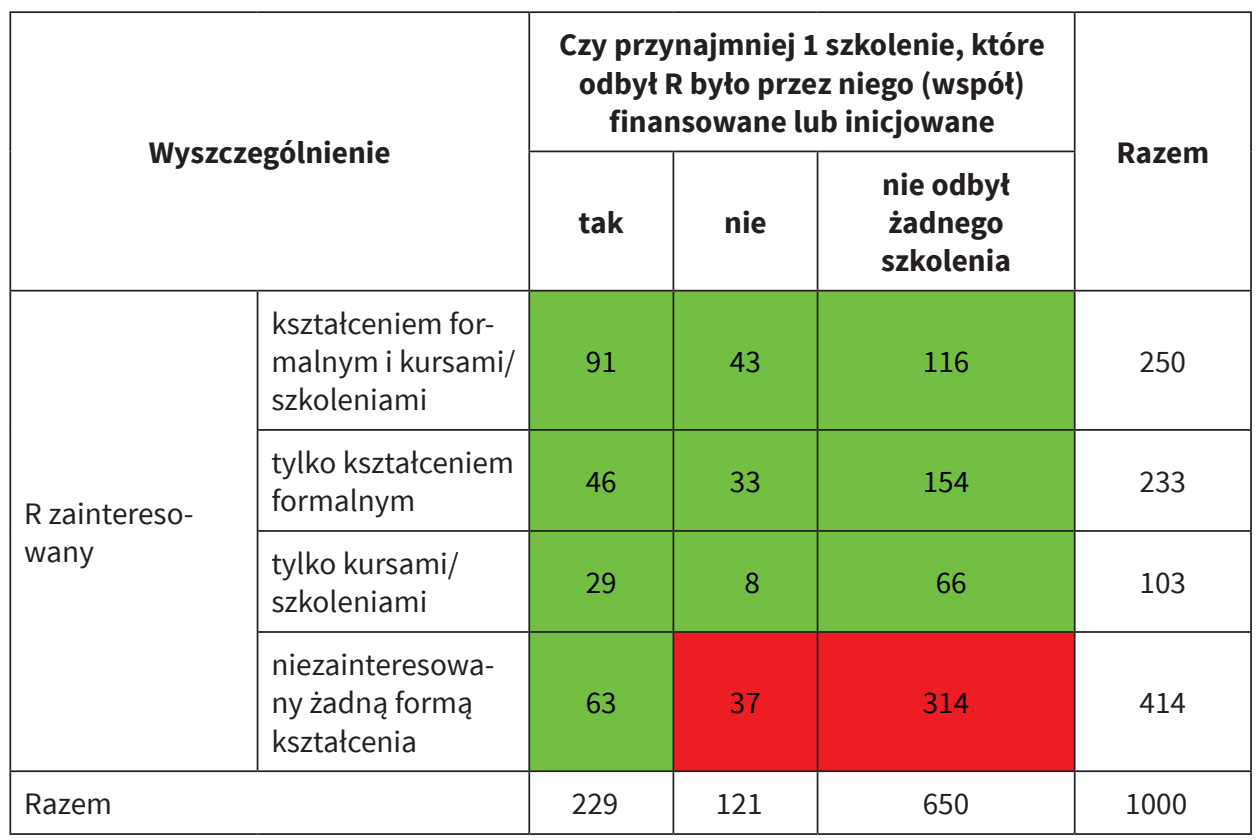

Źródto: opracowanie własne.

Oczywiście, ten sposób konstrukcji - jak każdy inny - ma określone konsekwencje. Dychotomizacja badanej własności ułatwia przeprowadzenie analizy metodą nieparametryczną, a także zwiększa czytelność jej wyników. Biorąc jednak pod uwagę, że dychotomizowana własność ma w istocie ilościowy charakter (liczba pozytywnych deklaracji; wartości od 0 do 3), operacja ta wpłynie na stopień wewnętrznej jednorodności powstających grup. Przyjęte tu rozwiązanie (minimum 1 deklaracja pozytywna na 3 możliwe) oznacza, że osoby odznaczające się potrzebą doskonalenia kwalifikacji będą stanowić zbiór bardziej wewnętrznie zróżnicowany (poziom potrzeby mniejszy, większy itd.) niż osoby 
nieodznaczające się tą cechą (zero deklaracji pozytywnych). Niejednorodność jednostek w obrębie grupy może z kolei przełożyć się na to, że znajdą się w niej osoby o zróżnicowanych standardach oceny. Jeżeli by szukać analogii w analizie wariancji i skorzystać z jej terminologii, to ten potencjalny problem można by ująć jako ryzyko dużego „DIF-u wewnątrzgrupowego”. Tymczasem, o ile odpowiedzi są obciążone błędem, to zmienna trafnie identyfikująca cechę, która ten błąd wywołuje powinna dawać wyniki w postaci dużego (większego) „DIF-u międzygrupowego” i małego (mniejszego) „DIF-u wewnątrzgrupowego”. Ostatecznie przyjęto to potencjalne ograniczenie, rezygnując z operowania zmienną ilościową, a także $\mathrm{z}$ rozwiązania zastosowanego w przypadku badania sytuacji materialnej, gdzie dychotomizując weryfikator założenia RC, wyeliminowano jednostki o środkowych wartościach cechy. Przed przyjęciem zmiennej w jej ostatecznym kształcie porównano wyniki analiz uzyskane przy zastosowaniu różnych jej wariantów. Decyzja ma więc także oparcie empiryczne, co zostanie dalej unaocznione.

\subsubsection{Ustalenie dominującego wzoru uporządkowania winiet}

Analizę mającą na celu ustalenie dominującego wzoru uporządkowania winiet poprzedzono przygotowaniem rozkładu odpowiedzi na pytania $\mathrm{z}$ winietami (tabela 19). Wyniki wzbogacono o informację na temat wartości średnich, które mogą dać wstępną sugestię co do stopnia, w jakim poszczególne winiety wyrażają natężenie badanej cechy.

Tabela 19. Rozkład odpowiedzi na pytania z winietami dotyczącymi potrzeby doskonalenia własnych kwalifikacji zawodowych $(n=1000)$

\begin{tabular}{|c|c|c|c|c|c|c|c|c|}
\hline Winieta & $\begin{array}{c}\mathbf{1 .} \\
\text { zdecydo- } \\
\text { wanie } \\
\text { nie }\end{array}$ & $\begin{array}{c}\mathbf{2 .} \\
\text { nie }\end{array}$ & $\begin{array}{c}\mathbf{3 .} \\
\text { raczej nie }\end{array}$ & $\begin{array}{c}\mathbf{4 .} \\
\text { raczej tak }\end{array}$ & $\begin{array}{c}\mathbf{5 .} \\
\text { tak }\end{array}$ & $\begin{array}{c}\mathbf{6 .} \\
\text { zdecydo- } \\
\text { wanie } \\
\text { tak }\end{array}$ & $\begin{array}{c}\text { Braki } \\
\text { danych }\end{array}$ & Średnia \\
\hline $1 / \mathrm{d} /$ & 163 & 272 & 308 & 125 & 89 & 24 & 19 & 2,77 \\
\hline $2 / \mathrm{b} /$ & 49 & 159 & 390 & 200 & 130 & 46 & 26 & 3,35 \\
\hline $3 / \mathrm{c} /$ & 20 & 68 & 304 & 269 & 234 & 88 & 17 & 3,90 \\
\hline $4 / \mathrm{a} /$ & 14 & 16 & 56 & 296 & 350 & 251 & 17 & 4,73 \\
\hline $5 / \mathrm{e} /$ & 3 & 10 & 35 & 163 & 297 & 480 & 12 & 5,20 \\
\hline
\end{tabular}

Źródto: opracowanie własne. 
Tabela 20. Wyniki diagnostyki winiet pod kątem zaburzeń dla uporządkowania 12345 ( $n=945)$ Macierz 1

\begin{tabular}{|c|c|c|c|c|c|}
\hline Winieta & $\mathbf{<}$ & $\mathbf{1}$ & $\mathbf{2}$ & $\mathbf{3}$ & $<\mathbf{5}$ \\
\hline 1 & & 0,516 & 0,652 & 0,808 & 0,844 \\
\hline 2 & 0,162 & & 0,466 & 0,717 & 0,784 \\
\hline 3 & 0,122 & 0,216 & & 0,578 & 0,672 \\
\hline 4 & 0,071 & 0,060 & 0,186 & & 0,469 \\
\hline 5 & 0,039 & 0,073 & 0,083 & 0,192 & \\
\hline
\end{tabular}

Komórki w trójkącie nad przekątną $\left(p_{i j}\right)$ informują, jaki odsetek stanowią przypadki poprawnych uporządkowań między wybraną parą winiet, np. $p_{12}=0,516$ mówi o udziale respondentów, którzy winiecie 1 przypisali niższą rangę niż winiecie 2 . Komórki w trójkącie pod przekątną $\left(p_{j i}\right)$ informują, jaki odsetek stanowią przypadki błędnych uporządkowań (misorderings) między wybraną parą winiet, np. $p_{21}=0,162$ mówi o udziale respondentów, którzy winiecie 2 przypisali wyższą rangę niż winiecie 1 .

\section{Macierz 2}

\begin{tabular}{|c|c|c|c|c|c|}
\hline Winieta & $\mathbf{1}$ & $\mathbf{2}$ & $\mathbf{3}$ & $\mathbf{4}$ & $\mathbf{5}$ \\
\hline 1 & & 0,354 & 0,530 & 0,737 & 0,805 \\
\hline 2 & 0,322 & & 0,250 & 0,657 & 0,711 \\
\hline 3 & 0,226 & 0,318 & & 0,392 & 0,589 \\
\hline 4 & 0,121 & 0,223 & 0,236 & & 0,277 \\
\hline 5 & 0,117 & 0,143 & 0,245 & 0,339 & \\
\hline
\end{tabular}

Komórki w trójkącie nad przekątną $\left(p_{i j}-p_{j i}\right)$ informują o różnicy między liczbą poprawnych i błędnych uporządkowań. Wartości ujemne oznaczają przewagę błędnych uporządkowań. Komórki w trójkącie pod przekątną $\left(1-p_{i j}-p_{j i}\right)$ informują, jaki odsetek stanowią przypadki powiązań (ties) między wybraną parą winiet, np. $1-p_{12}-p_{21}=0,322$ mówi o udziale respondentów, którzy przypisali tę samą rangę winiecie 1 i 2.

Źródto: opracowanie własne.

Analiza wyników macierzy (tabela 20.) potwierdza wcześniejsze, wstępne ustalenia - porządek winiet 12345 okazuje się najlepszy spośród wszystkich możliwych kombinacji. Przy tym układzie nie wystąpiły przypadki, w których liczba uporządkowań błędnych przewyższałaby liczbę poprawnych. Niemniej udział poprawnych uporządkowań jest dość mały. Zwraca też uwagę duża liczba powiązań. Co również niekorzystne, pojawiają się one nie tylko w odniesieniu do sąsiadujących winiet. Rezultatu tego nie można usprawiedliwić, jak w przypadku badania sytuacji materialnej, niekorzystną relacją między liczbą winiet a liczbą punktów skali. Pary winiet powodujące najwięcej zaburzeń to 2. i 3. oraz 4. i 5. (w obu przypadkach tylko około $47 \%$ uporządkowań poprawnych). 
Wystąpiły 194 różne wzory uporządkowań - to również niezbyt pomyślna informacja. Można przypomnieć, dla porównania, że w badaniu sytuacji materialnej, gdzie zastosowano 7 winiet, a nie 5, jak w tym przypadku, liczba tych wzorów wyniosła tylko 120.

Dziesięć najczęściej pojawiających się wzorów miało następującą postać (numery w klamrach odnoszą się do winiet, którym przyporządkowano tę samą rangę):

$$
\begin{aligned}
& 1,\{2,3\},\{4,5\} \\
& 1,\{2,3\}, 4,5 \\
& \{1,2\}, 3,\{4,5\} \\
& \{1,2\},\{3,4,5\} \\
& \{1,2,3\},\{4,5\} \\
& \{1,2\},\{3,4\}, 5 \\
& 1,2,3,4,5 \\
& 1,2,\{3,4\}, 5 \\
& \{1,2,3\}, 4,5 \\
& 1,\{2,3,4,5\}
\end{aligned}
$$

Należy zauważyć, że tylko 378 (40\%) respondentów udzieliło odpowiedzi zgodnych z porządkiem ; przypadek wystąpienia 1 błędnego uporządkowania odnotowano u 257 (27\%) respondentów, 2 takie przypadki u 121 (13\%) osób, a 3 lub więcej u 189 (20\%) osób - odsetki te znacząco się różnią (na niekorzyść) od analogicznych danych przy badaniu sytuacji materialnej.

Jakkolwiek więc liberalny test (towarzyszący metodzie nieparametrycznej) pozwala przyjąć, że zostało spełnione założenie VE, dokładniejsza analiza danych ujawnia niedomagania w tym względzie. Zdają się one świadczyć o pewnych słabościach skonstruowanego narzędzia - wymóg, aby winiety tworzyły jednowymiarową skalę nie został do końca spełniony. Rozpatrując ex post możliwe przyczyny tego stanu rzeczy, należy wskazać najprawdopodobniej nietrafioną koncepcję budowy winiet, zgodnie z którą miały one odzwierciedlać charakterystyczne w polskim społeczeństwie postawy wobec doskonalenia własnych kwalifikacji zawodowych, z uwzględnieniem specyficznych kontekstów, np. odnoszących się do miejsca pracy, motywów itd. Można też argumentować, że „doskonalenie kwalifikacji zawodowych" jest terminem wieloznacznym (doskonalić kwalifikacje zawodowe można na różne sposoby, nie tylko poprzez działania kończące się uzyskaniem dyplomu, świadectwa, itd.), a zatem trudnym do zapewnienia skali jednowymiarowości. Oceniając z obecnej perspektywy podjętą wcześniej decyzję odnośnie do własności poddanej badaniu, można przypuszczać, że lepszym rozwiązaniem byłoby obranie cechy oznaczonej nazwą bardziej jednoznaczną, o wyraźniejszym zakresie, np. dokształcanie w celu podniesienia kwalifikacji zawodowych (dodatkowo, propozycji takiej w pełni odpowiadałaby zmienna wybrana jako weryfikator założenia RC). 


\subsubsection{Wyniki metody nieparametrycznej}

Weryfikator założenia RC (wskaźnik potrzeby doskonalenia kwalifikacji zawodowych) jest najlepszą zmienną w zbiorze, która pozwala na ujawnienie istnienia błędu. Wyniki w tym względzie przedstawiono w tabeli 21 i na wykresach 25-29. Spodziewany układ wyników w wypadku wystąpienia międzygrupowego DIF to wyższe standardy oceny u osób zdefiniowanych jako posiadające potrzebę doskonalenia swoich klasyfikacji, co powinno się uwidocznić przesuniętą bardziej na lewą stronę masą prawdopodobieństwa i niższą wartością średnią niż ma to miejsce $\mathrm{w}$ przypadku osób takiej potrzeby nieposiadających. Ponadto efekt ten powinien być konsekwentnie obserwowany w przypadku każdej winiety. Innymi słowy, oczekuje się, że posiadający potrzebę będą zawsze bardziej „surowi” w ocenie każdej winietowej historyjki, przyznając jej niższe wartości na skali potrzeby doskonalenia kwalifikacji zawodowych. Jak widać, uzyskane wyniki nie odpowiadają w pełni temu oczekiwaniu.

Tabela 21. Rozkład ocen winiet w dwóch kategoriach wskaźnika potrzeby doskonalenia własnych kwalifikacji zawodowych (PD)

\begin{tabular}{|c|c|c|c|c|c|c|c|c|c|c|}
\hline Winieta & PD & $\begin{array}{c}1 . \\
\text { zdecydo- } \\
\text { wanie } \\
\text { nie }\end{array}$ & $\begin{array}{c}2 . \\
\text { nie }\end{array}$ & $\begin{array}{c}3 . \\
\text { raczej } \\
\text { nie }\end{array}$ & $\begin{array}{c}4 . \\
\text { raczej } \\
\text { tak }\end{array}$ & $\begin{array}{c}5 . \\
\text { tak }\end{array}$ & $\begin{array}{c}6 . \\
\text { zdecydo- } \\
\text { wanie } \\
\text { tak }\end{array}$ & n & $\bar{x}$ & $\mathbf{s}$ \\
\hline \multirow{2}{*}{$1 / d /$} & tak & 0,18 & 0,31 & 0,27 & 0,13 & 0,09 & 0,02 & 639 & 2,71 & 1,28 \\
\hline & nie & 0,14 & 0,22 & 0,40 & 0,12 & 0,09 & 0,03 & 342 & 2,89 & 1,23 \\
\hline \multirow{2}{*}{$2 / b /$} & tak & 0,05 & 0,17 & 0,42 & 0,19 & 0,12 & 0,05 & 633 & 3,33 & 1,19 \\
\hline & nie & 0,05 & 0,16 & 0,36 & 0,24 & 0,16 & 0,04 & 341 & 3,40 & 1,18 \\
\hline \multirow{2}{*}{$3 / c /$} & tak & 0,02 & 0,08 & 0,34 & 0,23 & 0,22 & 0,10 & 640 & 3,84 & 1,21 \\
\hline & nie & 0,01 & 0,04 & 0,25 & 0,35 & 0,27 & 0,08 & 343 & 4,04 & 1,06 \\
\hline \multirow{2}{*}{$4 / a /$} & tak & 0,01 & 0,02 & 0,06 & 0,28 & 0,35 & 0,28 & 640 & 4,79 & 1,03 \\
\hline & nie & 0,02 & 0,02 & 0,06 & 0,33 & 0,36 & 0,21 & 343 & 4,63 & 1,06 \\
\hline \multirow{2}{*}{$5 / e /$} & tak & 0,00 & 0,01 & 0,03 & 0,14 & 0,30 & 0,52 & 643 & 5,28 & 0,91 \\
\hline & nie & 0,00 & 0,01 & 0,05 & 0,21 & 0,31 & 0,42 & 345 & 5,07 & 0,99 \\
\hline
\end{tabular}

Źródło: opracowanie własne - dane nie uwzględniają odpowiedzi trudno powiedzieć.

Efekt zawyżonych standardów u posiadających potrzebę obserwujemy tylko w przypadku winiet $1,2,3$, natomiast przy 4 i 5, czyli winietach które przedstawiają wyższe poziomy badanej cechy, kierunek tych standardów zdaje się odwracać - przy ich ocenie osoby posiadające potrzebę dokształcania stają się bardziej „liberalne”, choć efekt ten nie jest zbyt wyraźny - pokazują go przede wszystkim 
wartości średnich. Generalnie, różnice w rozkładach są niewielkie, a w przypadku winiety 2 . i 4 ., test $c h i^{2}$ nie pozwala na odrzucenie hipotezy zerowej, mówiącej o niezależności rozkładów.

Winieta 1 (d)

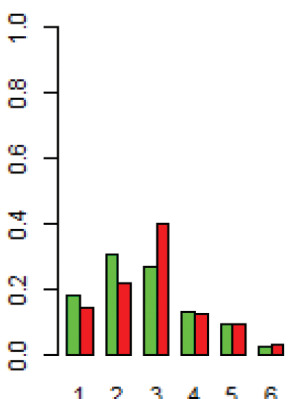

Winieta 4 (a)

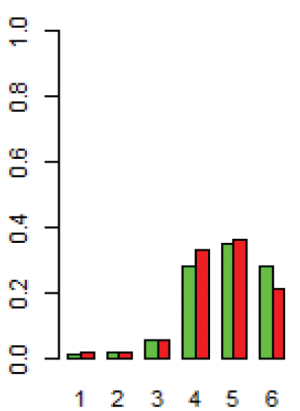

Winieta 2 (b)

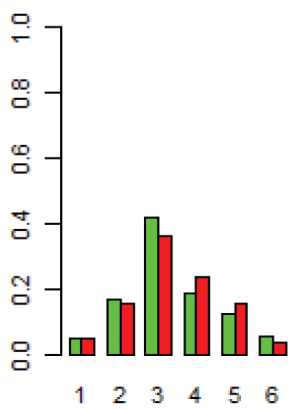

Winieta 5 (e)

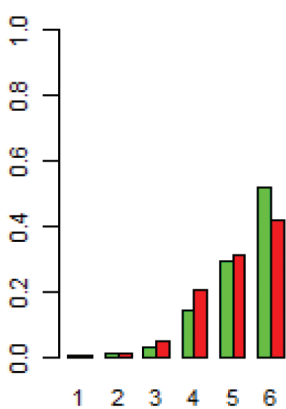

Winieta 3 (c)

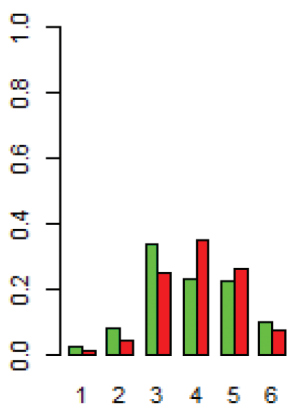

- Brak potrzeby

- Posiada potrzebę

Ocena na skali 1-6, gdzie:

1 - zdecydowanie nie

6 - zdecydowanie tak

Wykresy 25-29. Rozkład ocen winiet ze względu na posiadanie potrzeby doskonalenia własnych kwalifikacji zawodowych Źródło: opracowanie własne - wykresy na podstawie danych z tabeli 21.

Wyniki zdają się zatem wskazywać, że DIF międzygrupowy, o ile występuje, nie jest znaczny (można też dodać, że uzyskaniu istotnego wyniku testu, nawet przy niewielkich zależnościach, sprzyja duża liczebność próby). Z drugiej strony nie można zapomnieć, że wychwycenie tego błędu utrudniają niedoskonale skonstruowane winiety, co sugerują wysokie wartości odchylenia standardowego (tabela 21). Taka interpretacja tych wartości wynika $\mathrm{z}$ ich porównania $\mathrm{z}$ analogicznymi wartościami odchylenia standardowego, jakie otrzymano w przypadku badania sytuacji materialnej (tabela 12). Jednocześnie problemu nie można wyjaśnić przyjętą, dychotomiczną konstrukcją wskaźnika potrzeby doskonalenia własnych kwalifikacji, gdyż wysokie wartości odchylenia standardowego utrzymują się także $\mathrm{w}$ grupach wyznaczonych przez ilościową zmienną, mówiącą o liczbie pozytywnych deklaracji w zakresie dokształcania (0-3). Zjawisko to pośrednio unaoczniają wykresy $30-34$. 
Winieta 1 (d)

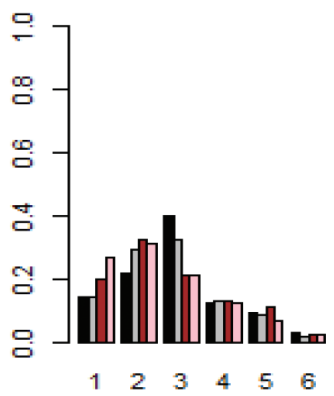

Winieta 4 (a)

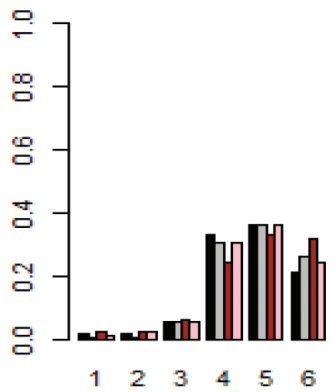

Winieta 2 (b)

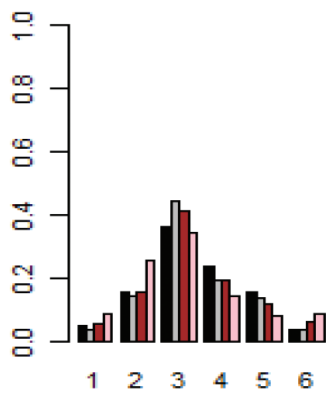

Winieta 5 (e)

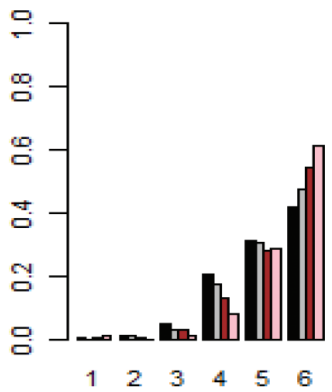

Winieta 3 (c)

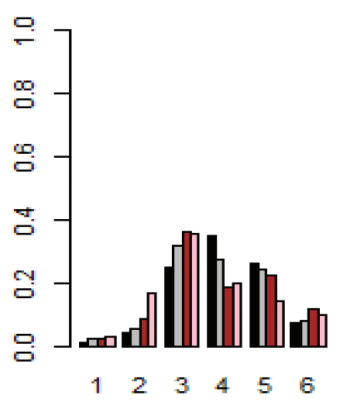

Wykresy 30-34. Rozkład ocen winiet w grupach wg liczby pozytywnych deklaracji w zakresie dokształcania się

Źródto: opracowanie własne.

Czy do ustaleń o braku znaczącego błędu pasują wyniki analizy rozkładu samooceny nieskorygowanej? Dane pozwalające na udzielenie odpowiedzi na to pytanie są zaprezentowane w tabeli 22 i na wykresach 35-36.

Tabela 22. Rozkład odpowiedzi na pytanie o samoocenę w zakresie potrzeby doskonalenia własnych kwalifikacji zawodowych

\begin{tabular}{|c|c|c|c|c|c|c|c|c|c|}
\hline Zbiór & $\begin{array}{c}\mathbf{1 .} \\
\text { zdecy- } \\
\text { dowanie } \\
\text { nie }\end{array}$ & $\begin{array}{c}\mathbf{2 .} \\
\text { nie }\end{array}$ & $\begin{array}{c}\mathbf{3 .} \\
\text { raczej } \\
\text { nie }\end{array}$ & $\begin{array}{c}\mathbf{4} \text { raczej } \\
\text { tak }\end{array}$ & $\begin{array}{c}\mathbf{5 .} \\
\text { tak }\end{array}$ & $\begin{array}{c}\mathbf{6 .} \\
\text { zdecy- } \\
\text { dowanie } \\
\text { tak }\end{array}$ & $\begin{array}{c}\text { Braki } \\
\text { danych }\end{array}$ & $\overline{\boldsymbol{X}}$ & $\mathbf{n}$ \\
\hline 1 & 2 & 3 & 4 & 5 & 6 & 7 & 8 & 9 & 10 \\
\hline \multirow{2}{*}{$\begin{array}{c}\text { Całość } \\
\text { próby }\end{array}$} & 49 & 143 & 158 & 194 & 218 & 231 & 7 & & 1000 \\
\cline { 2 - 10 } & 0,05 & 0,14 & 0,16 & 0,19 & 0,22 & 0,23 & 0,01 & & 1,00 \\
\hline \multirow{2}{*}{$\begin{array}{c}\text { Całość } \\
\text { (bez b.d.) }\end{array}$} & 49 & 143 & 158 & 194 & 218 & 231 & - & \multirow{2}{*}{4,09} & 993 \\
\cline { 2 - 10 } & 0,05 & 0,14 & 0,16 & 0,20 & 0,22 & 0,23 & - & 1,00 \\
\hline
\end{tabular}




\begin{tabular}{|c|c|c|c|c|c|c|c|c|c|}
\hline 1 & 2 & 3 & 4 & 5 & 6 & 7 & 8 & 9 & 10 \\
\hline \multirow{2}{*}{$\begin{array}{c}\text { PD - tak } \\
\text { (bez b.d.) }\end{array}$} & 13 & 46 & 62 & 134 & 177 & 212 & - & \multirow{2}{*}{4,63} & 644 \\
\cline { 2 - 9 } \cline { 3 - 8 } & 0,02 & 0,07 & 0,10 & 0,21 & 0,27 & 0,33 & - & & 1,00 \\
\hline $\begin{array}{c}\text { PD - nie } \\
\text { (bez b.d.) }\end{array}$ & 36 & 97 & 96 & 60 & 41 & 19 & - & \multirow{3}{*}{3,09} & 349 \\
\cline { 2 - 9 } & 0,10 & 0,28 & 0,28 & 0,17 & 0,12 & 0,05 & - & & 1,00 \\
\hline
\end{tabular}

Źródło: opracowanie własne.
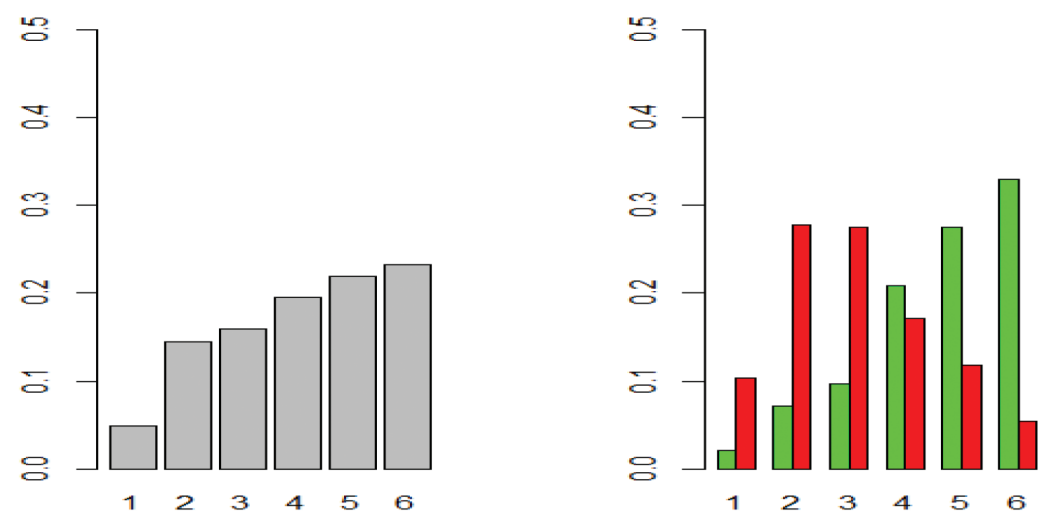

- Całość próby

- Brak potrzeby

Posiada potrzebę

Ocena na skali 1-6, gdzie: 1 - zdec. nie, 6 - zdec. tak.

Wykresy 35-36. Rozkład odpowiedzi na pytanie o samoocenę w zakresie potrzeby doskonalenia własnych kwalifikacji zawodowych Źródło: opracowanie własne - wykresy na podstawie danych z tabeli 22.

Pierwszy ogląd danych potwierdza to ustalenie - rozkłady samooceny dla odznaczających się i nieodznaczających się potrzebą dokształcania są niemal swoimi lustrzanymi odbiciami. W przypadku tych pierwszych obserwuje się lewoskośność, a w przypadku drugich - prawoskośność, zatem masy prawdopodobieństwa są rozłożone po odpowiednich stronach skali. Jednak przez wzgląd na konstrukcję wskaźnika można było spodziewać się nieco innych kształtów rozkładów - o ile rezultaty dla posiadających potrzebę nie budzą zastrzeżeń, bo rozciągnięcie rozkładu można wytłumaczyć wewnętrznym zróżnicowaniem jednostek w tej grupie, o tyle - wobec jednorodności drugiej grupy - można było oczekiwać większego skupienia rozkładu, a także większego udziału respondentów w kategorii 1. (zdecydowanie nie). 
Sięgając z powrotem po ilościową zmienną, pozwalającą na ogląd rozkładów w grupach utworzonych ze względu na liczbę pozytywnych deklaracji dotyczących dokształcania się (wykres 37), można stwierdzić pewną prawidłowość - wraz ze wzrostem liczby deklaracji nie tylko rośnie średnia samooceny, lecz także zmniejsza się rozstęp i wartość odchylenia standardowego, rozkłady stają są bardziej skupione $^{13}$. Jak można to wstępnie wyjaśnić? Wydaje się, że samoocena osób zgłaszających 0 lub 1 deklarację, a więc „obiektywnie” wykazujących się niższym poziomem potrzeby doskonalenia swoich kwalifikacji, podlega prawdopodobnie podobnym mechanizmom, jak ocena własnej sytuacji materialnej osób z I grupy tercylowej dochodu. Wysoka samoocena części tych osób może być wyjaśniona DIF-em (obniżonymi standardami oceny) lub błędem społecznej poprawności, który jest efektem prezentowania się respondenta przed ankieterem w pozytywnym świetle, zgodnie ze społecznie cenionymi wartościami. Proponowane wyjaśnienia mają charakter komplementarny w tym sensie, że w omawianej grupie mogą wystąpić oba zjawiska. Można w tym miejscu przypomnieć, że technika winiet zakotwiczających jest remedium tylko na pierwsze $\mathrm{z}$ wymienionych zjawisk - koryguje błąd wynikający z posiadania przez respondentów różnych standardów oceny, ale już nie radzi sobie z błędem społecznej poprawności, gdyż ten bezpośrednio uderza w fundamentalne dla całej techniki założenie RC.

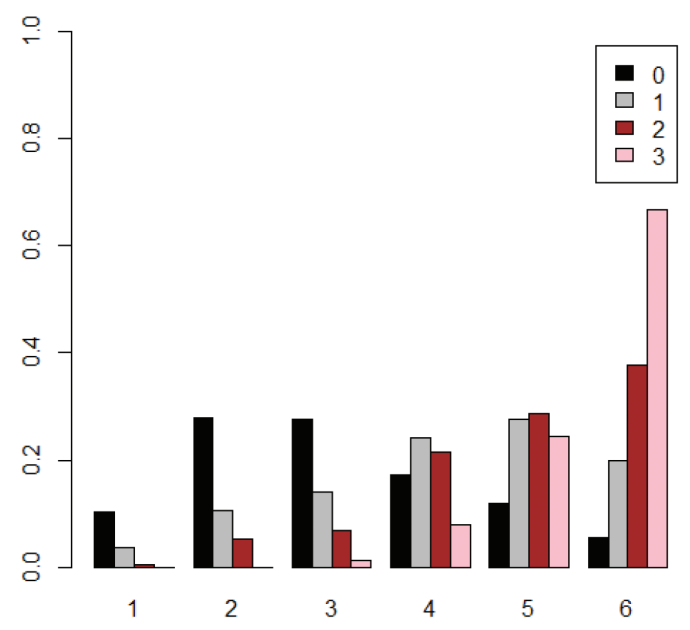

Wykresy 37. Rozkład samooceny potrzeby doskonalenia własnych kwalifikacji zawodowych w grupach wg liczby pozytywnych deklaracji

Źródto: opracowanie własne.

Rozkład samooceny skorygowanej (skala C) dla całości próby przedstawiono w tabeli 23 i na wykresach $38-41$.

13 Dane prezentowane tylko na wykresie. 
Tabela 23. Rozkłady samooceny potrzeby doskonalenia własnych kwalifikacji zawodowych po skorygowaniu metodą nieparametryczną - wyniki dla zestawu 12345

\begin{tabular}{|c|c|c|c|c|}
\hline C & $\begin{array}{c}\text { Bez obserwacji } \\
\text { wektorowych }\end{array}$ & $\begin{array}{c}\text { Alokacja } \\
\text { równomierna }\end{array}$ & $\begin{array}{c}\text { Alokacja } \\
\text { wg censored } \\
\text { ordered probit }\end{array}$ & $\begin{array}{c}\text { Alokacja } \\
\text { przy minimum } \\
\text { entropii }\end{array}$ \\
\hline 1 & 0,216 & 0,121 & 0,126 & 0,113 \\
\hline 2 & 0,106 & 0,086 & 0,091 & 0,056 \\
\hline 3 & 0,043 & 0,057 & 0,041 & 0,022 \\
\hline 4 & 0,045 & 0,076 & 0,074 & 0,140 \\
\hline 5 & 0,051 & 0,071 & 0,062 & 0,027 \\
\hline 6 & 0,037 & 0,080 & 0,067 & 0,019 \\
\hline 7 & 0,086 & 0,097 & 0,104 & 0,045 \\
\hline 8 & 0,088 & 0,118 & 0,161 & 0,404 \\
\hline 9 & 0,033 & 0,073 & 0,037 & 0,017 \\
\hline 10 & 0,141 & 0,125 & 0,142 & 0,074 \\
\hline 11 & 0,157 & 0,096 & 0,095 & 0,082 \\
\hline $\mathrm{n}$ & 491 & 935 & 935 & 935 \\
\hline
\end{tabular}

Źródło: opracowanie własne.

Bez obserwacji wektorowych Alokacja równomierna
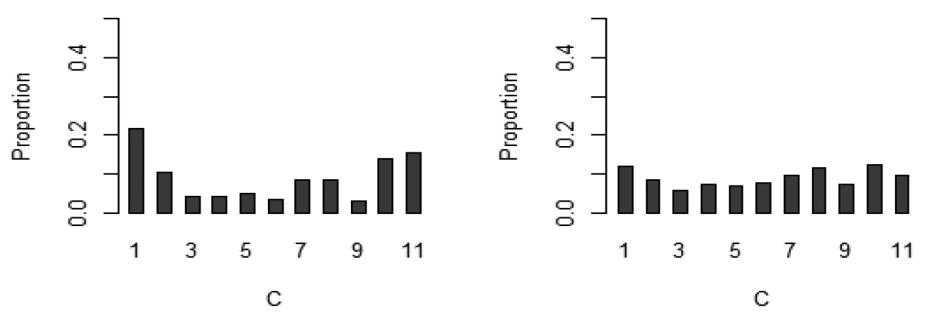

Alokacja wg censored ordered probit

Alokacja przy minimum entropii
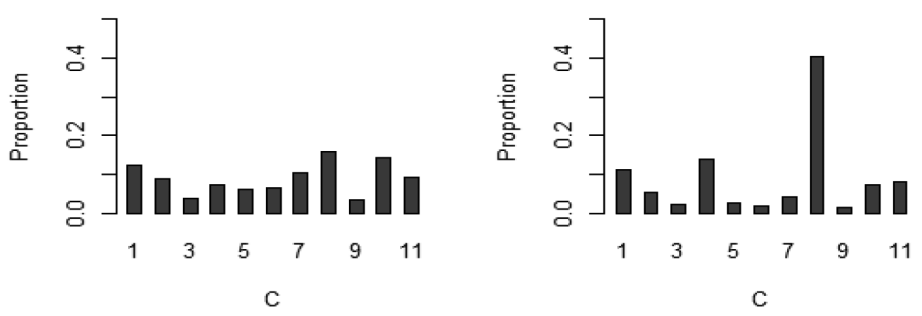

Wykresy 38-41. Rozkłady samooceny potrzeby doskonalenia własnych kwalifikacji zawodowych po skorygowaniu metodą nieparametryczną

- wyniki dla zestawu 12345

Źródto: opracowanie własne - wykresy na podstawie danych z tabeli 23. 
Wprawdzie poszczególne warianty rozkładów różnią się między sobą, co jest konsekwencją występowania dużej liczby przypadków wektorowych, ale można jednak zauważyć ustąpienie lewoskośności, charakterystycznej dla kształtu rozkładu samooceny przed korektą (wykres 35). Dociążenie lewego krańca skali - obserwowane wyraźnie dla rozkładu wartości skalarnych (wykres 39), czy w mniejszym stopniu dla rozkładu opartego na alokacji równomiernej oraz rozkładu na bazie przewidywań modelu probitowego ${ }^{14}$ - sugeruje efektywną korektę błędu w odniesieniu do osób nie odznaczających się potrzebą doskonalenia kwalifikacji zawodowych.

Stosunkowy mały udział jednostek $\mathrm{z}$ wynikiem $\mathrm{c}=9$ (poziom między winietą 4. i 5.) zapowiada problem z możliwością późniejszej predykcji tego wyniku przez model regresji w grupach wskaźnika potrzeby doskonalenia kwalifikacji zawodowych - otrzymany raport z wyników potwierdza istnienie tej przeszkody, co unaoczniają wykresy $42-45$.

Bez obserwacji wektorowych

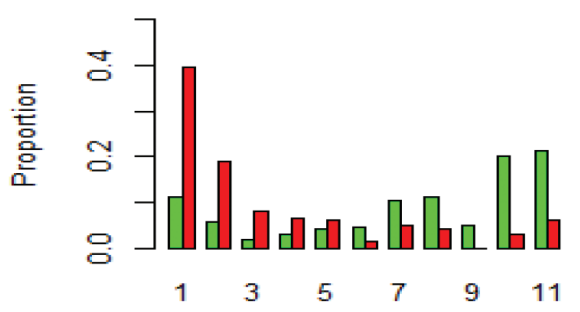

C

Alokacja wg censored ordered probit

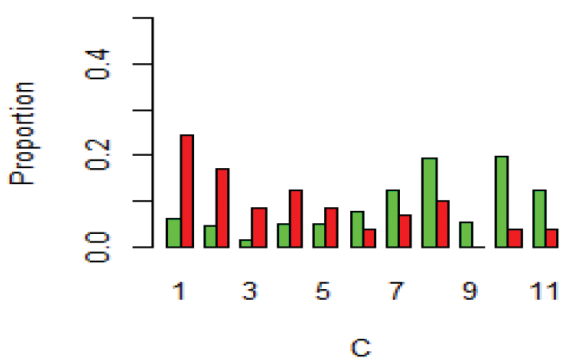

Alokacja równomierna

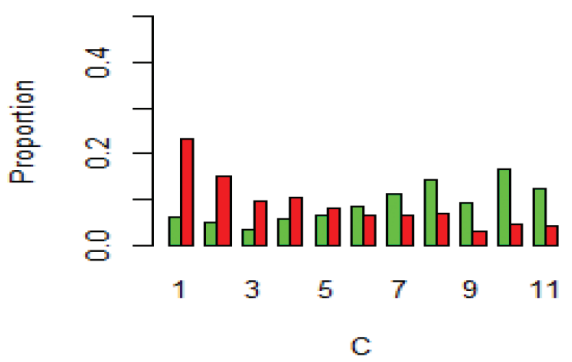

Alokacja przy minimum entropii

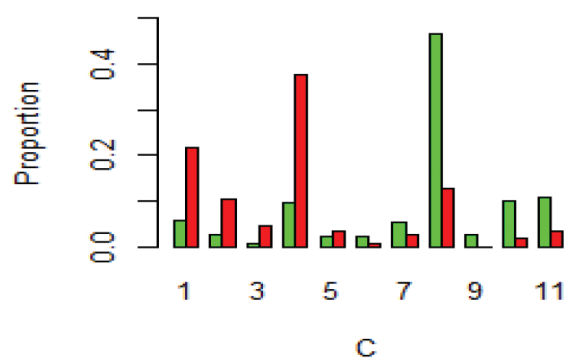

Wykresy 42-45. Rozkłady samooceny po skorygowaniu metodą nieparametryczną w dwóch grupach wskaźnika potrzeby doskonalenia własnych kwalifikacji zawodowych - wyniki dla zestawu 12345

Źródto: opracowanie własne.

14 W analizie regresji wykorzystano następujące zmienne niezależne: płeć ( $K=1, M=0)$, wskaźnik doskonalenia własnych kwalifikacji zawodowych ( $1=$ potrzeba występuje, $0=$ nie występuje), wykształcenie ( $1=$ wyższe, $0=$ pozostałe), wiek, gmina miejska $(1=$ tak, $0=$ nie $)$. 
Wobec tego, mając jednocześnie w pamięci problemy w zakresie zaburzeń, jakie wystąpiły w uporządkowaniu winiet, zdecydowano o pomniejszeniu ich zestawu do dalszych analiz. Dokonując wyboru winiet, wzięto dodatkowo pod uwagę wyniki analizy ich mocy dyskryminacyjnej.

Do usunięcia wytypowano winiety 2. oraz 4. Pierwszy powód - nie miały one zdolności wychwycenia międzygrupowego DIF; drugi - były „uwikłane” w najczęściej występujące zaburzenia. Proponowane rozwiązanie okazało się też wysoce zadowalające ze względu na moc dyskryminacyjną zestawu 135, który wśród zestawów trzyelementowych osiągnął najwyższe wartości entropii ${ }^{15}$. Nadmienić można, że oczywiście zabieg ten nie usunął wszystkich wcześniejszych problemów, w tym defektów winiet utrzymanych w zestawie (wysokie wartości odchylenia standardowego w podgrupach; zmieniający się kierunek standardów oceny w podgrupach). Natomiast jeszcze inną zaletą tego posunięcia było zwiększenie odsetka jednostek z wynikiem skalarnym z 52,5\% do 83,2\%. W konsekwencji uzyskano bardzo zbliżone (przy okazji, dość spłaszczone) rozkłady samooceny skorygowanej (tabela 24 i wykresy 46-49).

Tabela 24. Rozkłady samooceny potrzeby doskonalenia własnych kwalifikacji zawodowych po skorygowaniu metodą nieparametryczną - wyniki dla zestawu 135

\begin{tabular}{|c|c|c|c|c|}
\hline C & $\begin{array}{c}\text { Bez obserwacji } \\
\text { wektorowych }\end{array}$ & $\begin{array}{c}\text { Alokacja równo- } \\
\text { mierna }\end{array}$ & $\begin{array}{c}\text { Alokacja wg } \\
\text { censored ordered } \\
\text { probit }\end{array}$ & $\begin{array}{c}\text { Alokacja } \\
\text { przy minimum } \\
\text { entropii }\end{array}$ \\
\hline 1 & 0,170 & 0,147 & 0,147 & 0,154 \\
\hline 2 & 0,120 & 0,123 & 0,121 & 0,124 \\
\hline 3 & 0,118 & 0,124 & 0,124 & 0,098 \\
\hline 4 & 0,094 & 0,121 & 0,114 & 0,078 \\
\hline 5 & 0,158 & 0,164 & 0,169 & 0,138 \\
\hline 6 & 0,190 & 0,189 & 0,196 & 0,284 \\
\hline 7 & 0,149 & 0,132 & 0,130 & 0,124 \\
\hline$n$ & 798 & 959 & 959 & 959 \\
\hline
\end{tabular}

Źródto: opracowanie własne.

15 Wartość entropii obliczana dla przypadków skalarnych (ang. known entropy) to 1,928, a szacowana na podstawie analizy regresji wynosi 1,863 . Wartości tych miar dla wyjściowego zestawu 12345 to odpowiednio 2,309 oraz 1,914. 
Bez obserwacji wektorowych

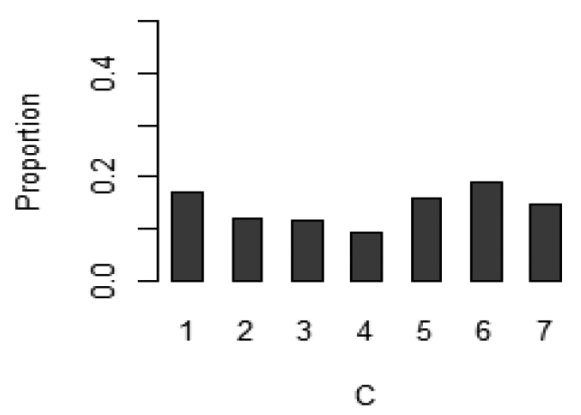

Alokacja wg censored ordered probit

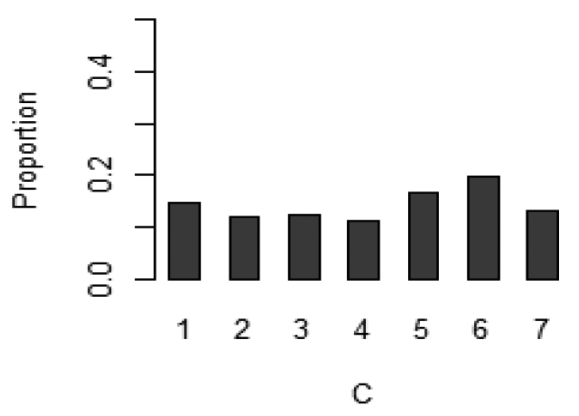

Alokacja równomierna

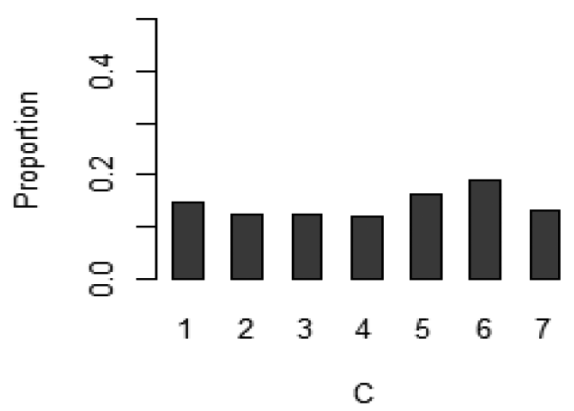

Alokacja przy minimum entropii

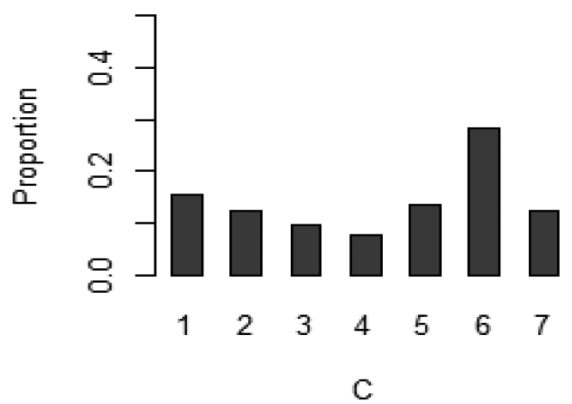

Wykresy 46-49. Rozkłady samooceny potrzeby doskonalenia własnych kwalifikacji zawodowych po skorygowaniu metodą nieparametryczną - wyniki dla zestawu 135

Źródło: opracowanie własne - wykresy na podstawie danych z tabeli 24.

Po zmniejszeniu liczby winiet w zestawie wcześniej zaobserwowane prawidłowości nie podlegają zasadniczym zmianom.

W odniesieniu do jednostek zaklasyfikowanych jako nieposiadające potrzeby doskonalenia kwalifikacji zawodowych odnotowuje się wyższe wartości frakcji w niższych punktach skali - to rezultat zgodny z oczekiwaniem wobec metody (tabela 25, wykresy 50-53). Ale już wydłużenie prawego ramienia rozkładu i udział respondentów rzędu $1 \frac{1}{4}$, którzy nie wykazując inicjatywy w zakresie dokształcania i lokują się na poziomie powyżej winiety 3. (punkty 5, 6, 7 skali) nasuwa myśl o obciążeniu wyników błędem społecznej poprawności. Dane zdają się potwierdzać słuszność tego kierunku myślenia. Okazuje się, że blisko 91\% respondentów $\mathrm{z}$ tej grupy, dokonując przed ankieterem samooceny stwierdziło, że taką potrzebę posiada (31\% odpowiedziało raczej tak; 37\% tak, $23 \%$ zdecydowanie tak) $)^{16}$.

16 Analiza mogła zostać przeprowadzona tylko na zbiorze jednostek z wynikiem skalarnym, gdzie $n=65$. 
Tabela 25. Rozkłady samooceny po skorygowaniu metodą nieparametryczną w podgrupach wskaźnika doskonalenia własnych kwalifikacji zawodowych - wyniki dla zestawu 135

\begin{tabular}{|c|c|c|c|c|c|c|c|c|}
\hline \multirow{2}{*}{ C } & \multicolumn{2}{|c|}{$\begin{array}{c}\text { Bez obserwacji } \\
\text { wektorowych }\end{array}$} & \multicolumn{2}{c|}{$\begin{array}{c}\text { Alokacja } \\
\text { równomierna }\end{array}$} & \multicolumn{2}{c|}{$\begin{array}{c}\text { Alokacja } \\
\text { wg censored } \\
\text { ordered probit }\end{array}$} & \multicolumn{2}{c|}{$\begin{array}{c}\text { Alokacja } \\
\text { przy minimum } \\
\text { entropii }\end{array}$} \\
\cline { 2 - 9 } & PD - nie & PD - tak & PD - nie & PD - tak & PD - nie & PD - tak & PD - nie & PD - tak \\
\hline 1 & 0,332 & 0,083 & 0,286 & 0,072 & 0,288 & 0,071 & 0,312 & 0,069 \\
\hline 2 & 0,211 & 0,071 & 0,204 & 0,080 & 0,213 & 0,072 & 0,252 & 0,059 \\
\hline 3 & 0,157 & 0,097 & 0,163 & 0,104 & 0,171 & 0,099 & 0,150 & 0,080 \\
\hline 4 & 0,068 & 0,108 & 0,098 & 0,133 & 0,089 & 0,126 & 0,057 & 0,112 \\
\hline 5 & 0,089 & 0,195 & 0,099 & 0,199 & 0,098 & 0,207 & 0,108 & 0,173 \\
\hline 6 & 0,071 & 0,255 & 0,083 & 0,245 & 0,078 & 0,260 & 0,060 & 0,350 \\
\hline 7 & 0,071 & 0,191 & 0,067 & 0,166 & 0,064 & 0,166 & 0,060 & 0,158 \\
\hline $\mathrm{n}$ & 280 & 518 & 333 & 626 & 333 & 626 & 333 & 626 \\
\hline
\end{tabular}

Źródto: opracowanie własne.

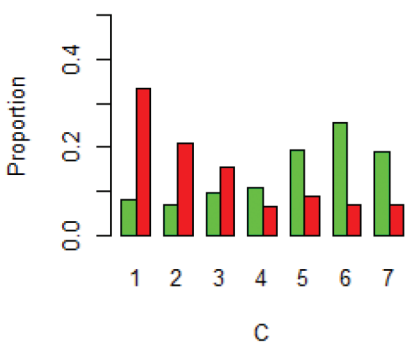

Alokacja wg censored ordered probit

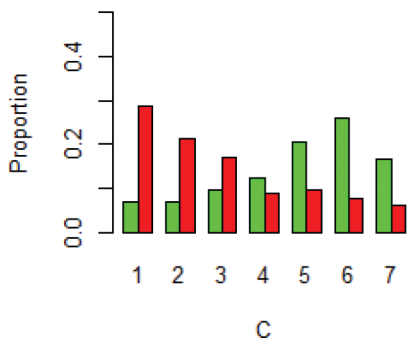

Alokacja przy minimum entropii

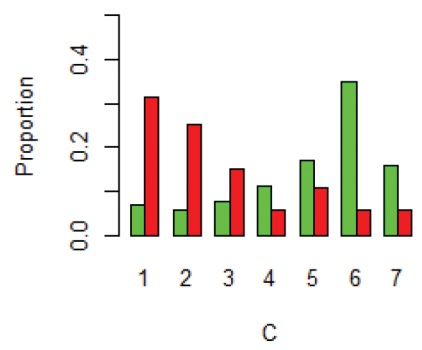

Wykresy 50-53. Rozkłady samooceny po skorygowaniu metodą nieparametryczną w podgrupach wskaźnika doskonalenia własnych kwalifikacji zawodowych - wyniki dla zestawu 135 Źródło: opracowanie własne - wykresy na podstawie danych z tabeli 25. 
W rozkładzie jednostek zdefiniowanych jako odznaczające się potrzebą doskonalenia kwalifikacji zawodowych (wykresy 50-53) nie obserwuje się większych zmian w porównaniu z rozkładem wyjściowym (wykres 36), poza wyraźnym zmniejszeniem odsetka badanych w najwyższej wartości skali. Obserwację tę dość łatwo wyjaśnić. Dopóki respondenci oceniali winiety według podwyższonych standardów, metoda „przesuwała” masę prawdopodobieństwa na prawo. Jednak - jak już wcześniej sygnalizowano - $\mathrm{w}$ odniesieniu do winiety 5 . prawidłowość ta przestała się utrzymywać w grupie „potrzebujących”, dlatego przyznanie najwyższej oceny winiecie 5. (6-zdecydowanie tak) uniemożliwiało osiągnięcie najwyższego poziomu na skali C.

Efektem opisanych przesunięć w obu grupach jest bardziej płaski rozkład dla całości próby (wykresy 46-49) - stracił on swą wyjściową lewoskośność (wykres 35), która wskazywała, że w badanej grupie potrzeba doskonalenia kwalifikacji zawodowych lokuje się u większości respondentów powyżej średniej. Opisane prawidłowości dodatkowo ilustrują wykresy 54-55.
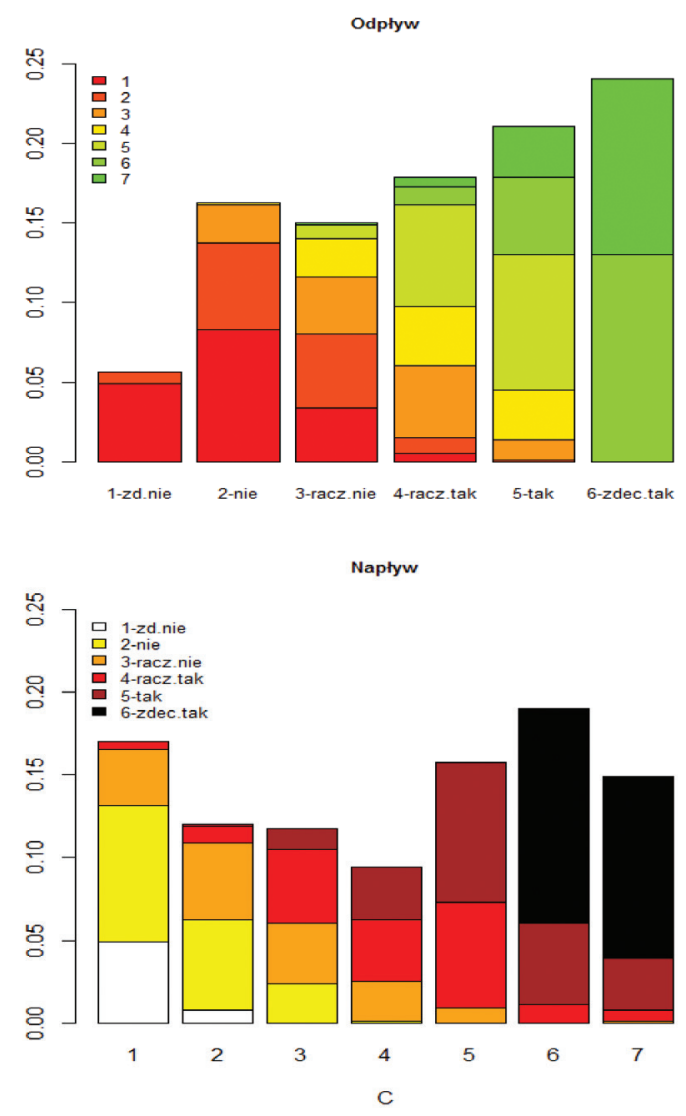

Wykresy 54-55. Przepływy wartości między samooceną nieskorygowaną a skorygowaną (dla wariantu „Bez wartości wektorowych”)

Źródto: opracowanie własne 


\subsubsection{Wyniki metody parametrycznej}

Wyniki analizy przeprowadzonej metodą parametryczną nie wskazują wystąpienia międzygrupowego DIF, o czym w pierwszym rzędzie świadczą niemal takie same wartości parametru beta zarówno w modelu porządkowym probit, jak i w modelach CHOPIT w odniesieniu do wskaźnika potrzeby doskonalenia własnych kwalifikacji zawodowych. Bardzo zbliżone oszacowania dają też wszystkie modele dla pozostałych zmiennych (tabela 26).

Tabela 26. Oszacowania regresji dla modelu porządkowego probit oraz modeli CHOPIT

\begin{tabular}{|c|c|c|c|c|c|c|}
\hline \multirow{2}{*}{$\begin{array}{c}\text { Wyszczególnie- } \\
\text { nie }\end{array}$} & \multicolumn{2}{|c|}{ Model ordered probit } & \multicolumn{2}{|c|}{$\begin{array}{c}\text { Model CHOPIT } \\
\text { (zestaw winiet: } \\
12345 \text { ) }\end{array}$} & \multicolumn{2}{|c|}{$\begin{array}{c}\text { Model CHOPIT } \\
\text { (zestaw winiet: 135) }\end{array}$} \\
\hline & wartość & $\begin{array}{l}\text { błąd } \\
\text { stan. }\end{array}$ & wartość & $\begin{array}{l}\text { błąd } \\
\text { stan. }\end{array}$ & wartość & błąd stan. \\
\hline 1 & 2 & 3 & 4 & 5 & 6 & 7 \\
\hline \multicolumn{7}{|c|}{ Zmienne wyjaśniające $(\beta)$} \\
\hline Płeć (kobieta) & $-0,025$ & 0,068 & $-0,019$ & 0,073 & $-0,030$ & 0,076 \\
\hline Wiek & $-0,022^{\star \star}$ & 0,003 & $-0,025^{\star \star}$ & 0,004 & $-0,025^{\star \star}$ & 0,004 \\
\hline $\begin{array}{l}\text { Wykształcenie } \\
\text { (wyższe) }\end{array}$ & $0,435^{\star \star}$ & 0,080 & $0,480^{\star \star}$ & 0,086 & $0,511^{\star *}$ & 0,090 \\
\hline $\begin{array}{l}\text { Gmina miejska } \\
\text { (tak) }\end{array}$ & 0,043 & 0,068 & 0,124 & 0,073 & 0,124 & 0,077 \\
\hline PD (tak) & $0,941^{\star \star}$ & 0,078 & $0,923^{\star \star}$ & 0,083 & $0,944^{\star *}$ & 0,087 \\
\hline \multicolumn{7}{|l|}{ Próg $1(\gamma 1)$} \\
\hline Płeć (kobieta) & & & $-0,009$ & 0,054 & $-0,053$ & 0,066 \\
\hline Wiek & & & $-0,001$ & 0,003 & $-0,003$ & 0,003 \\
\hline $\begin{array}{l}\text { Wykształcenie } \\
\text { (wyższe) }\end{array}$ & & & 0,002 & 0,061 & 0,070 & 0,075 \\
\hline $\begin{array}{l}\text { Gmina miejska } \\
\text { (tak) }\end{array}$ & & & $0,145^{\star}$ & 0,054 & 0,082 & 0,066 \\
\hline PD (tak) & & & 0,109 & 0,061 & $0,173^{*}$ & 0,075 \\
\hline Stała & $-2,076$ & 0,181 & $-2,244$ & 0,219 & $-2,178$ & 0,235 \\
\hline \multicolumn{7}{|l|}{ Próg $2(y 2)$} \\
\hline Płeć (kobieta) & & & 0,033 & 0,071 & 0,083 & 0,081 \\
\hline Wiek & & & 0,002 & 0,003 & 0,005 & 0,004 \\
\hline
\end{tabular}


Tabela 26 (cd.)

\begin{tabular}{|c|c|c|c|c|c|c|}
\hline 1 & 2 & 3 & 4 & 5 & 6 & 7 \\
\hline $\begin{array}{l}\text { Wykształcenie } \\
\text { (wyższe) }\end{array}$ & & & 0,011 & 0,080 & $-0,005$ & 0,094 \\
\hline $\begin{array}{l}\text { Gmina miejska } \\
\text { (tak) }\end{array}$ & & & $-0,056$ & 0,072 & 0,047 & 0,082 \\
\hline PD (tak) & & & $-0,019$ & 0,078 & $-0,009$ & 0,091 \\
\hline Stała & $-0,377$ & 0,045 & $-0,423$ & 0,179 & $-0,577$ & 0,212 \\
\hline \multicolumn{7}{|l|}{ Próg $3(\gamma 3)$} \\
\hline Płeć (kobieta) & & & 0,042 & 0,049 & 0,045 & 0,061 \\
\hline Wiek & & & $-0,003$ & 0,002 & $-0,004$ & 0,003 \\
\hline $\begin{array}{l}\text { Wykształcenie } \\
\text { (wyższe) }\end{array}$ & & & $0,145^{\star}$ & 0,055 & 0,110 & 0,070 \\
\hline $\begin{array}{l}\text { Gmina miejska } \\
\text { (tak) }\end{array}$ & & & $-0,017$ & 0,050 & 0,000 & 0,061 \\
\hline PD (tak) & & & $-0,127^{\star}$ & 0,054 & $-0,232^{\star \star}$ & 0,066 \\
\hline Stała & $-0,290$ & 0,037 & $-0,152$ & 0,125 & $-0,054$ & 0,154 \\
\hline \multicolumn{7}{|l|}{ Próg $4(\gamma 4)$} \\
\hline Płeć (kobieta) & & & $-0,075$ & 0,051 & $-0,071$ & 0,066 \\
\hline Wiek & & & $-0,002$ & 0,002 & $-0,003$ & 0,003 \\
\hline $\begin{array}{l}\text { Wykształcenie } \\
\text { (wyższe) }\end{array}$ & & & $-0,050$ & 0,059 & $-0,061$ & 0,077 \\
\hline $\begin{array}{l}\text { Gmina miejska } \\
\text { (tak) }\end{array}$ & & & $-0,029$ & 0,051 & $-0,013$ & 0,066 \\
\hline PD (tak) & & & $-0,166^{\star \star}$ & 0,054 & $-0,174^{\star}$ & 0,071 \\
\hline Stała & $-0,482$ & 0,037 & $-0,227$ & 0,126 & $-0,219$ & 0,161 \\
\hline \multicolumn{7}{|l|}{ Próg $5(\gamma 5)$} \\
\hline Płeć (kobieta) & & & $-0,034$ & 0,049 & $-0,042$ & 0,061 \\
\hline Wiek & & & $-0,004^{\star}$ & 0,002 & $-0,002$ & 0,003 \\
\hline $\begin{array}{l}\text { Wykształcenie } \\
\text { (wyższe) }\end{array}$ & & & $-0,107$ & 0,057 & $-0,111$ & 0,071 \\
\hline $\begin{array}{l}\text { Gmina miejska } \\
\text { (tak) }\end{array}$ & & & $-0,101^{\star}$ & 0,050 & $-0,193^{\star *}$ & 0,062 \\
\hline PD (tak) & & & $-0,091$ & 0,054 & $-0,043$ & 0,069 \\
\hline
\end{tabular}




\begin{tabular}{|l|c|c|c|c|c|c|}
\hline \multicolumn{1}{|c|}{1} & 2 & 3 & 4 & 5 & 6 & 7 \\
\hline Stała & $-0,319$ & 0,036 & 0,007 & 0,124 & $-0,070$ & 0,155 \\
\hline Winiety \\
\hline$\theta_{1}-$ winieta 1/d/ & & & $-1,297$ & 0,189 & $-1,262$ & 0,197 \\
\hline$\theta_{2}-$ winieta 2/b/ & & & $-0,867$ & 0,187 & & \\
\hline$\theta_{3}-$ winieta 3/c/ & & & $-0,464$ & 0,186 & $-0,428$ & 0,195 \\
\hline$\theta_{4}-$ winieta 4/a/ & & & 0,147 & 0,186 & & \\
\hline$\theta_{5}-$ winieta 5/e/ & & & 0,584 & 0,188 & 0,615 & 0,196 \\
\hline In $(\sigma)$ & & & $-0,174$ & 0,032 & $-0,151$ & 0,034 \\
\hline Log likelihood & $-8732,646$ & $-8675,477$ & $-5769,444$ \\
\hline
\end{tabular}

* Współczynnik istotny na poziomie $p<0,05 ;{ }^{* \star}$ współczynnik istotny na poziomie $p<0,01$.

Źródto: opracowanie własne.

Obserwacje te skłaniają do wniosku, że samoocena trafnie informuje o prawdziwych wartościach badanej cechy. Adekwatne do tego ustalenia są bardzo niskie wartości parametrów gamma świadczące o minimalnych różnicach w standardach oceny między osobami zakwalifikowanymi jako odznaczające się oraz nieodznaczające się potrzebą doskonalenia swoich kwalifikacji. W trakcie prowadzenia analiz nieparametrycznych systematycznie śledzono kierunki drobnych różnic w rozkładach, tymczasem wyniki regresji - uwzględniającej dodatkowo błędy o charakterze losowym - pokazują prostszy w tym względzie obraz. Rozważano, czy otrzymany tu rezultat to w jakiejś części efekt zniesienia się zmieniających się kierunków standardów ocen w podgrupach. Z tego względu sprawdzono wartość parametru beta dla wskaźnika PD po wyeliminowaniu winiety 5 /e/. Wartość ta, przy zestawie winiet: 13, wynosi 0,981, a więc jest tylko nieco wyższa, ale kierunek „przesunięcia” jest zgodny z oczekiwanym, czyli wartość prawdziwa cechy u osób odznaczających się potrzebą dokształcania jest na minimalnie wyższym, a u osób nieodznaczających się na minimalnie niższym poziomie niż wskazywałyby na to samooceny. Wnioski te, przypomnijmy, mogą zostać przyjęte pod warunkiem spełnienia założenia RC, ale ten - częściowo przynajmniej - podważają wyniki analizy nieparametrycznej.

Wyniki analiz nieparametrycznych były też podstawą do sformułowania pewnych wątpliwości odnośnie do poprawności skonstruowanego narzędzia i tego, czy winiety tworzą jednowymiarowe kontinuum. Wprawdzie wyniki parametrycznego testu założenia VE mówią o jego spełnieniu (dla obu zestawów winiet wartości theta tworzą rosnące kontinuum), a lemając na względzie wysokie wartości odchylenia standardowego w rozkładach ocen winiet w podgrupach sprawdzono, czy wykształcenie będące zmienną dość silnie związaną z badaną cechą, nie jest powodem DIF-u wewnątrzgrupowego. Przy kontroli zmien- 
nej „wykształcenie wyższe”, wartość beta dla wskaźnika PD osiąga poziom 0,927 (w równaniu zestaw winiet 12345). W świetle tego rezultatu podtrzymanie wspomnianych wątpliwości wydaje się zasadne.

\subsection{Podsumowanie}

Uzyskane rezultaty badań z wykorzystaniem techniki winiet zakotwiczających pokazują, że w badanej populacji zjawisko zróżnicowanych standardów oceny występuje w niewielkim stopniu. Można argumentować, że wniosek ten wydawał się dość prawdopodobny jeszcze przed podjęciem empirycznych studiów, skoro populacja jest jednorodna pod względem kulturowym i geograficznie nierozprzestrzeniona. Zainicjowaniu badań towarzyszyło jednak nieco inne przypuszczenie, które mówiło, że źródłem zróżnicowania standardów oceny może być ulokowanie w strukturze społeczno-demograficznej, a także doświadczenia jednostek. Jak jednak pokazały wyniki, DIF między grupami nie ma znaczących rozmiarów. Oczywiście ustalenia te odnoszą się zasadniczo tylko do zbadanych własności - z pewnością istnieją dziedziny, w których zdobycie określonych doświadczeń diametralnie zmienia sposób wartościowania oraz postrzegania siebie i otaczającej rzeczywistości.

$\mathrm{Z}$ dwóch badanych cech, własnością której warto poświęcić więcej uwagi i omówić uzyskane dla niej wyniki jest z pewnością sytuacja materialna w gospodarstwie domowym. Informacja na jej temat jest jedną z głównych poszukiwanych w każdym niemal badaniu sondażowym. Jednocześnie właśnie w przypadku tej cechy ujawnił się większy błąd DIF. Czy na podstawie wyników przeprowadzonego badania można sformułować jakieś rekomendacje mówiące o tym, jak zadawać pytania, aby uzyskać trafne informacje? Czy można polegać na samoocenie, tym bardziej, że mniej osób uchyla się od odpowiedzi na takie pytanie, czy jednak prosić o podanie kwoty zarobków?, A może zalecić stosowanie winiet jako stałej praktyki badawczej? Wydaje się, że na tym etapie badania formułowanie wniosków w tym względzie jest przedwczesne, $\mathrm{z}$ tego chociażby względu, że zbadano małą populację, która nie jest reprezentatywną próbką dorosłych Polaków (można chociażby wskazać, że w przebadanym zbiorze niedoreprezentowane są osoby o wysokich zarobkach). Trzeba też przypomnieć, że realizacji badania przyświecał nieco inny cel. Nie było ono ukierunkowane bezpośrednio na badanie tej cechy, ani nastawione na szukanie najlepszych metod jej pomiaru - akcent był przesunięty na problem rozmiaru błędu i wstępne przetestowanie samej techniki, w tym odniesienie się do jej założeń, a przede wszystkim założenia o konsekwencji odpowiedzi (założenie RC). Stąd też zastosowany tu sposób rozwiązania problemu (np. ograniczenie zbioru tylko do jednostek pochodzących z I i III grupy tercylo- 
wej dochodu) nie jest uniwersalny i wydaje się nie najlepiej dopasowany do badań o odmiennych celach. Z tego względu bezpieczną, ale też uczciwą wskazówką wydaje się w tej chwili kontynuacja badań z zastosowaniem winiet zakotwiczających. Być może okaże się, że nieco inny zestaw winiet byłby bardziej odpowiedni do badania populacji dorosłych Polaków. Pogłębienia wymaga też kwestia rozmiaru błędu społecznej poprawności, którego występowanie ujawniło się w pytaniach o samoocenę. Jak już pisano, technika winiet zakotwiczających nie jest w stanie go skorygować. Jeżeli błąd ten byłby duży, byłoby to przeciwwskazanie nie tylko do poszukiwania informacji o sytuacji materialnej poprzez pytanie o samoocenę - również polecanie techniki winiet zakotwiczających jako stałej praktyki badawczej nie miałoby większego sensu. Niewykluczone jednak, że i w tym zakresie tkwi w technice pewien potencjał - wprawdzie nieparametryczna metoda nie skorygowała social desirability bias, ale go ujawniła (parametryczna metoda, przy wszystkich swoich walorach, nie ma tej zdolności). Być może jest to obiecujący krok na drodze do znalezienia jakichś metod jego adiustowania, ustalenia odpowiednich wag poprawiających szacunki itp.

Mechanizmów prowadzących do tego, że jednostka potrafi ocenić inaczej jedną i tę samą sytuację w zależności od tego, czy dotyczy ona jej samej, czy innych osób, jest wiele. Błąd społecznej poprawności nie jest jedynym, który może uderzać w założenie o konsekwencji odpowiedzi. Zresztą już sam koncept potrzeby aprobaty społecznej, leżący u podstaw tego błędu, jest złożony i opisuje różne sposoby realizacji tej potrzeby (świadome versus nieświadome zniekształcanie obrazu własnej osoby, czyli samooszukiwanie się versus autoprezentacja „pod” odbiorcę) (por. Paulhus, Reid 1991). Przedstawianie się w nadmiernie pozytywnym świetle jest też charakterystyczne dla zjawiska błędnej atrybucji przyczyn sukcesów i niepowodzeń polegającym na tym, że sukcesy jednostka zwykle postrzega jako efekt własnych zasług, natomiast źródeł niepowodzeń upatruje w działaniu czynników zewnętrznych - prawidłowość ta nie działa już w przypadku oceny innych (Wilgenburg van 2010). Mówiąc w uproszczeniu, self-serving attributional bias wynika ze skłonności do przeceniania własnej osoby i niedoceniania innych. Taki jest też mechanizm self-favoring biases: pozytywne cechy jednostka częściej przypisuje sobie niż innym (ang. illusory superiority), własną przyszłość widzi bardziej optymistycznie niż przyszłość innych (ang. unrealistic optimism) (Hoorens 2015). Jednostka, jak widać, ma tendencję do postrzegania świata w zgodzie z własnym interesem, ale jego realizacja nie musi polegać tylko na podnoszeniu własnego ja. Obserwuje się, że dla uzasadnienia własnego stanu czy postępowania, osiągnięcia zdefiniowanego przez siebie profitu, jednostka potrafi oceniać się niekorzystnie - w zgodzie z tą prawidłowością osoby bez pracy mają tendencję do oceny swojego stanu zdrowia jako gorszego niż jest, co tłumaczy się jako efekt szukania usprawiedliwienia dla pozostawania na bezrobociu (Wilgenburg van 2010). Mówiąc krótko, liczba odkrytych przez badaczy społecznych prawidłowości rządzących zakrzywianiem własnego obrazu jest na tyle pokaźna, że trudno zgodzić się z autorami techniki winiet zakotwiczających, 
kiedy piszą, że przypadki, w których nie jest spełnione założenie RC obejmują sytuacje ekstremalne (Anchoring... 2009: 7).

Co mówią ustalenia innych badaczy, którzy poświęcili temu problemowi uwagę? Kapteyn i współautorzy (2011) poddali badaniu pięć własności z dziedziny zdrowia: problemy ze snem, poruszaniem się, koncentracją, oddychaniem oraz nastrojem psychicznym. Jedynie w odniesieniu do tej pierwszej cechy stwierdzono spełnienie założenia RC. Szczególnie duże odstępstwa odnotowano w przypadku problemów z koncentracją i oddychaniem - te same problemy zdrowotne respondenci postrzegali jako bardziej poważne, kiedy dotyczyły innych (czyli osób przedstawionych w winiecie) niż ich samych. Przyczyn, dla których wyniki badań okazały się tak różne w odniesieniu do pokrewnych w końcu własności autorzy upatrywali w konstrukcji narzędzia i wynikających z tego efektach kontekstu (badania prowadzone na dużym panelu internetowym). Badania $\mathrm{w}$ tym zakresie kontynuował K. van Wilgenburg (2010). Zgodnie z otrzymanymi przez niego wynikami, założenie RC nie było spełnione w odniesieniu do żadnej badanej cechy - problemów ze spaniem, nadużywaniem alkoholu, nastrojem - przy czym w tym przypadku respondenci mieli skłonność do oceniania siebie gorzej niż innych. Wilgenburg wykluczył ponadto możliwość objaśnienia tego wyniku konstrukcją narzędzia (badania prowadzone na grupie studentów). Rezultaty nakazujące odrzucić założenie RC uzyskali jeszcze inni badacze - T. Bago d’Uva i współpracownicy (2009) w odniesieniu do zdolności koncentracji i zapamiętywania oraz problemów z poruszaniem się (populacja Brytyjczyków w wieku 50+). Odmienne rezultaty otrzymali H. Grol-Prokopczyk i współautorzy (2011), którzy prowadzili badania nad problemami ze wzrokiem oraz poruszaniem się - tu wyniki nakazały podtrzymać słuszność założenia RC (sondaż WHS). Niestety, jak widać, żaden wspólny wzór nie wyłania się z dotychczasowych studiów.

Warto tu dodać, że badania nad sprawdzeniem założenia RC są w różny sposób prowadzone. Niektórzy korzystają z w pełni zewnętrznych pomiarów, np. w badaniu nad ostrością wzroku w populacji Słowaków i Chińczyków, weryfikatorem RC były medyczne pomiary w tym zakresie (King i in. 2004). Inni taką obiektywną miarę próbują pozyskać na bazie informacji pozyskanych w sondażu. Tu przykładem są badania nad poczuciem wpływu na rządzących wśród Chińczyków i Meksykanów (King i in. 2004), a także przeprowadzone przez nas badania. W takich przypadkach weryfikator RC jest zwykle zmienną, o której jednocześnie sądzi się, że różnicuje standardy oceny. Jeszcze inny, pomysłowy sposób odniesienia się do prawdziwości założenia RC zastosowali Kapteyn i współpracownicy (2011) oraz Wilgenburg (2010), którzy sprawdzali, czy respondent tak samo odpowiada, gdy dokonuje oceny siebie oraz tzw. winiety-repliki. Winieta-replika opisuje poziom cechy, któremu dokładnie odpowiada dany respondent (informacje potrzebne do winiety-repliki pozyskuje się podczas I fali badania panelowego). Nie można wykluczyć, że sposób dobrania weryfikatora RC jest źródłem uzyskiwania różnych rezultatów badań. W końcu, wymienione studia różni też poziom zaawansowania analiz statystycznych - zastosowane tu podejście jest $\mathrm{w}$ tym zakresie znacznie 
mniej wyszukane np. w porównaniu z testami zaproponowanymi przez T. Bago d'Uva (2009).

Podobne badania prowadzi się w odniesieniu do słuszności założenia o ekwiwaletności winiet (VE), z tym jednak zastrzeżeniem, że ich wyniki świadczą nie tyle o użyteczności techniki jako takiej, ile o dobroci konkretnego narzędzia. $\mathrm{Na}$ tym polu uzyskano również odmienne rezultaty, nakazujące odrzucić bądź podtrzymać założenie. Nasze doświadczenia związane z badaniem potrzeby doskonalenia własnych kwalifikacji zawodowych pokazały, że szczególną uwagę należy przywiązywać do sposobu operacjonalizacji konstruktów abstrakcyjnych i wieloznacznych - dbać o to, aby winiety prezentowały różne stopnie jednego wymiaru, nawet kosztem upraszczania rzeczywistości, a także przetestować przygotowane narzędzie w badaniu pilotażowym.

Założenia techniki winiet zakotwiczających „nie są niewinne” (Kristensen, Johansson 2008) i „nie można ich przyjmować na wiarę” (Grol-Prokopczyk i in. 2011) - taka konkluzja wydaje się najsłuszniejsza w świetle rezultatów własnych badań, a także zrelacjonowanych ustaleń innych badaczy. Dla metodologów oznacza to potrzebę kontynuowania badań nad techniką, a użytkownikom należy zalecić rozwagę w jej stosowaniu. 



\section{Zakończenie}

Prezentowana w tym opracowaniu refleksja wpisuje się w szerszy nurt namysłu nad wartością danych, uzyskiwanych w procesie badawczym, a może nawet w refleksję nad tym, w jakim stopniu badania mogą odzwierciedlać rzeczywistość. W głowach metodologów - i to nie tylko tych skłonnych tropić błędy i niedostatki badań socjologicznych - pojawiają się pytania o rzetelność badań, o jakość całego procesu badawczego, o wiarygodność otrzymanych rezultatów. Czy zadając pytania o opinie rzeczywiście docieramy do tego, co nasi respondenci sądzą na dany temat, czy też musimy zadowolić się tylko powierzchownymi, formułowanymi „na poczekaniu” oficjalnymi opiniami, którymi badani zechcą się z nami podzielić? Ten brak pewności co do jakości otrzymanych rezultatów, a przez to i jakości badań socjologicznych skłania do szukania ciągle nowych sposobów oceniania zebranego materiału.

Podręczniki prezentujące metodykę badań socjologicznych są wykładami o „dobrej robocie” - zwracają uwagę na poprawność warsztatu. Instruują socjologów, jak poprawnie przeprowadzić badanie, jakie etapy przejść. Innymi słowy, pokazują, czasami nie szczędząc czytelnikom najdrobniejszych szczegółów, jakimi konsekwencjami dla badaczy i badanych może skutkować brak refleksji nad poszczególnymi etapami lub zbyt powierzchowna realizacja pewnych założeń. Dzięki takim lekturom socjologowie są świadomi tego, co to znaczy zrobić badania, jak wiele elementów musi się na nie złożyć i jakie mają one znaczenie dla powodzenia całości przedsięwzięcia. Dużą wagę przywiązuje się zatem do właściwej konceptualizacji badań, odpowiedniego zaplanowania całej procedury badawczej, właściwego doboru zjawisk do badań, poprawnej konstrukcji narzędzi badawczych, starannego przeszkolenia osób wykonujących badanie, wnikliwego prowadzenia procedur kontrolnych oraz skrupulatnej i pomysłowej analizy zebranego materiału. Oczywiście każdy z tych etapów może być obarczony jakimś błędem, który należy zidentyfikować, a następnie albo mu zapobiec (jeśli jest na to czas), albo go uwzględnić (opisując rezultaty z niezwykłą ostrożnością). Gdyby porównać cały proces badawczy do procedur pomiarowych, to można by stwierdzić, że tylko dla pewnych jego elementów można przyjąć kategorie trafności i rzetelności (przypisywane skalom pomiarowym). Zebrane dane są trafne, jeśli utrwalone są w nich informacje o zjawiskach, które badacz rzeczywiście chciał badać. Natomiast ocena rzetelności wymaga rozstrzygnięcia, czy to odzwierciedlenie rzeczywistości społecznej zostało zrobione dokładnie. 
Analizy weryfikacyjne Jana Lutyńskiego i metoda winiet zakotwiczających zdają się w tym kontekście procedurami podnoszącymi jakość uzyskiwanych danych i zwiększającymi pewności co do zebranego materiału. Chociaż różnią się istotnymi aspektami, to jednak oba przedsięwzięcia wpisują się w tę wielopokoleniową, metodologiczną „dobrą robotę” oraz refleksję nad możliwościami opisania świata społecznego przez badania.

Kilkadziesiąt lat temu J. Lutyński pisał, że nie ma „[...] efektywnych sposobów pozwalających oszacować rozmiar błędów, których źródłem jest niedoskonałość zastosowanej techniki otrzymywania danych (non sampling errors, response errors, measurement errors). W rezultacie nie można więc oszacować wielkości błędu w całości” (Lutyński 1994: 209-210). Ten, jak się zdaje, nieusuwalny problem ma kluczowe znaczenie. Socjologowie, nie mając pewności co do prawdziwości wyników własnych badań i tego, w jakim stopniu odzwierciedlają one społeczną rzeczywistość, ufają rezultatom badań w znacznie mniejszym stopniu niż przedstawiciele innych nauk. W efekcie trudniej jest im czynić z wniosków badań zalecenia do stosowania w praktyce. Ma to również konsekwencje metodologiczne. Przy uzyskaniu różnych rezultatów nie są w stanie ustalić, który z wyników jest bardziej trafny, czyli lepiej oddaje rzeczywistość społeczną, a co za tym idzie, którą ze stosowanych technik wykorzystać do badania danego zjawiska. A także, co szczególnie istotne dla metodologów, jakie wady i słabości ma dana technika w sytuacji, gdy nie da się (najlepiej liczbowo) określić rezultatu jej stosowania (Lutyński 1994: 211).

Podobną refleksję na temat jakości danych uzyskiwanych w badaniach socjologicznych, a w szczególności w badaniach surveyowych, podjął Franciszek Sztabiński, związany z łódzką szkołą metodologiczną i uprawiający metodologię w duchu tej szkoły. Jej efektem jest książka Ocena jakości danych w badaniach surveyowych (2011), w której prezentuje różne sposoby oceny jakości danych, podzielone na wewnętrzne, związane albo z oceną poszczególnych etapów procesu badawczego, albo z szacowaniem błędów pojawiających się w tych etapach oraz zewnętrzne, powiązane z takimi pojęciami, jak: trafność, rzetelność, weryfikacja, walidacja. Badacz proponuje również narzędzia, które można wykorzystać do oceny jakości danych. Można je podzielić na dwie grupy. Pierwszą stanowią narzędzia pośrednie, pomagające wykryć błędy związane $z$ realizacją próby i prowadzeniem wywiadu z odpowiednio dobranym respondentem. W drugiej znajdziemy narzędzia bezpośrednie, których można użyć do oceny uzyskanego wyniku. To podejście, chociaż zogniskowane wokół problemu oceny jakości danych, wpisuje się w nurt podejmowania pewnych zabiegów w ramach badań socjologicznych, które podnosiłyby jakość procedur badawczych i uzyskiwanych na ich drodze materiałów.

Na koniec warto dać czytelnikowi podsumowanie w postaci porównania koncepcji analiz weryfikacyjnych $\mathrm{z}$ winietami zakotwiczającymi.

Po pierwsze, zdecydowanie inna jest metryka każdej z tych procedur: koncepcja weryfikacji zewnętrznej i wewnętrznej J. Lutyńskiego powstała na przełomie lat 60 . i 70. XX w., podczas gdy pierwsze doniesienia w artykułach naukowych na temat winiet datowane są na początek XXI w. Kilkadziesiąt lat to dla rozwoju nauki niemal 
wieczność, szczególnie jeśli czas ten obejmuje gwałtowne przyspieszenie technologiczne. Gdy J. Lutyński wraz z zespołem tworzył, miał do dyspozycji jedynie maszyny obliczeniowe Odra, które mogły wykonać tylko niektóre analizy matematyczne. Ogromną część pracy wykonywano „ręcznie”, co nieporównywalnie bardziej angażowało badaczy i zdecydowanie wydłużało czas przeznaczony na opracowanie wyników. Rezultaty zastosowania winiet dają się obliczyć bardzo szybko dzięki wykorzystaniu nowoczesnego oprogramowania komputerowego. Te kilkadziesiąt lat to także ogromny przyrost refleksji metodologicznej na temat jakości badań socjologicznych per se, a w szczególności bardzo popularnych badań surveyowych. Refleksja ta jest oparta na wynikach badań podejmowanych specjalnie po to, by poszukiwać, choćby częściowych, odpowiedzi na pytania metodologiczne.

Po drugie, analizy weryfikacyjne mogły być realizowane tylko przez zespół badawczy, ponieważ "globalne” podejście do procedury weryfikacyjnej czyniły tę koncepcję niedostępną dla pojedynczych socjologów. Tylko zaangażowanie dużego zespołu badawczego już na etapie zbierania materiałów, a potem w fazie analizowania daje możliwość przeprowadzenia całej procedury. Pojedynczy badacze nie podejmą się zebrania danych dokumentarnych, prowadzenia wywiadów pogłębionych czy wywiadów po wywiadzie. $Z$ winietami sprawa ma się inaczej. Ankieterzy, którzy i tak realizują badanie, mają zadać respondentom jedynie kilka, kilkanaście dodatkowych pytań, a uzyskane w tej sposób rezultaty są w stanie przeanalizować pomysłodawcy umieszczenia winiet w konkretnym badaniu.

Po trzecie, również otrzymane rezultaty różnią się w zasadniczy sposób. W przypadku winiet zakotwiczających możemy zweryfikować informacje zebrane za pomocą kilku pytań z kwestionariusza, przy czym wyniki tej procedury pozwalają na ocenę tylko pewnego rodzaju informacji zebranych za pomocą danego narzędzia. Istotne jest też to, że potwierdzenie uzyskuje się, stosując za każdym razem tę samą metodą, czyli konstruując i zadając wiele pytań-winiet, które przynależą do tego samego pytania. W analizach weryfikacyjnych poddaje się oglądowi więcej elementów procesu uzyskiwania materiałów, a także stosuje się dodatkowe, uzupełniające metody. Wywiady pogłębione oraz wywiady o wywiadzie mogą dotyczyć tych samych pytań z kwestionariusza, dzięki czemu metodolog ma możliwość porównania rezultatów zebranych za pomocą różnych metod.

Jednak bez względu na to, którą z procedur weryfikacyjnych będziemy rozpatrywać, zawsze jej zastosowanie wydłuża badanie. Powoduje, że zarówno badacze (konstruując dodatkowe pytania, docierając do dokumentów, prowadząc wywiady), jak i badani (biorąc udział w znacznie dłuższych wywiadach, analizując proces, na podstawie którego odpowiadali na pytania, wypełniając testy słownikowe itp.) muszą włożyć większy wysiłek w badanie. Wszystkie te zabiegi stosowane są po to, by móc ocenić jakość zebranego materiału, jakość danej techniki badawczej i wreszcie jakość samych badań socjologicznych.

Z punktu widzenia osób prowadzących współcześnie badania socjologiczne procedura winiet zakotwiczających wydaje się stosunkowo łatwa zarówno do zastosowania, jak i analizy materiałów. Analizy weryfikacyjne jednak są, w naszym odbio- 


\section{Zakończenie}

rze, koncepcją, która przynosząc wartości naukowe staje wielką metodologiczną przygodą, intelektualnym doświadczeniem, którą się wspomina, ocenia, analizuje z perspektywy nawet kilkudziesięciu lat i do której wciąż się wraca, próbując porównać $\mathrm{z}$ aktualnie funkcjonującymi procedurami. Próbę takiej analizy przedstawiłyśmy w tym tomie Analiz i prób technik badawczych w socjologii. 


\section{Bibliografia}

Abramson P.R., Aldrich J.H. (1982), The decline of electoral participation in America, "American Political Science Review", Vol. 76, 502-521

Analizy i próby technik badawczych w socjologii, t. I (1966). Gostkowski Z. (red.), Wrocław-Warszawa-Kraków: Ossolineum.

Analizy i próby technik badawczych w socjologii, t. II (1968). Gostkowski Z., Lutyński J. (red.), Wrocław-Warszawa-Kraków: Ossolineum.

Analizy i próby technik badawczych w socjologii, t. III (1970). Gostkowski Z., Lutyński J. (red.), Wrocław-Warszawa-Kraków: Ossolineum.

Analizy i próby technik badawczych w socjologii, t. VIII (1990). Gostkowski Z. (red.), Wrocław-Warszawa-Kraków: Ossolineum.

Analizy i próby technik badawczych $w$ socjologii. Problemy humanizacji procesu badawczego, t. IX (1992). Gostkowski Z. (red.), Warszawa: Wydawnictwo IFiS PAN. Analizy i próby technik badawczych w socjologii. Sondaże opinii społecznej. Samowiedza współczesnych społeczeństw, t. X (2001). Gostkowski Z., Daniłowicz P. (red.), Łódź: Wydawnictwo IFiS PAN.

Analizy i próby technik badawczych $w$ socjologii. Społeczne obrazy i stereotypy chłopa, urzędnika i robotnika. Studia eksploracyjne, t. VII (1989). Gostkowski Z. (red.), Wrocław-Warszawa-Kraków-Gdańsk-Łódź: Ossolineum.

Analizy i próby technik badawczych $w$ socjologii. Studia pilotażowe i analizy weryfikacyjne, t. V (1975). Gostkowski Z., Lutyński J. (red.), Wrocław-WarszawaKraków-Gdańsk: Ossolineum.

Analizy $i$ próby technik badawczych $w$ socjologii. Wywiad kwestionariuszowy w świetle badań metodologicznych, t. IV (1972). Gostkowski Z., Lutyński J. (red.), Wrocław-Warszawa-Kraków-Gdańsk: Ossolineum.

Anchoring vignettes: Frequently Asked Questions (2009), http://gking.harvard.edu/ files/ gking/files/vfaq.pdf (dostęp 2011).

Atzmüler C., Steiner P.M. (2010), Experimental vignette studies in survey research, "Methodology", Vol. 6 (3), 128-138

Bago d'Uva T., Lindeboomm M., O’Donnell O., van Doorslaer E. (2009), Slipping anchor? Testing the vignette approach to identification and correction of reporting heterogeneity, Discussion Paper, Amsterdam-Rotterdam, The Netherlands: Tinbergen Insitute. 
Bakker R., Vries de C., Edwards E., Jolly S., Polk J., Rovny J., Steenberg M. (2014), Anchoring the experts: using vignettes to compare party ideology across countries, "Research and Politics", October-December, http://rap.sagepub.com/content/ sprap/ 1/3/2053168014553502.full.pdf (dostęp 2014).

Banks J., Marmot M., Oldfield Z., Smith J.P. (2006), The SES health gradient on both sides of Atlantic, NBER Working Paper Series, Working paper 12674.

Czapiński J., Panek T. (2011), Diagnoza społeczna 2011. Warunki i jakość życia Polaków. Raport, Warszawa: Rada Monitoringu Społecznego.

Daniłowicz P., Sztabiński P.B. (1986), Zmienne osobowe $w$ badaniach socjologicznych. Analizy weryfikacyjne. Lutyńska K., Lutyński J. (red.), Analizy i próby technik badawczych $w$ socjologii, t. VI, Wrocław-Warszawa-Kraków-GdańskŁódź: Ossolineum.

Gostkowski Z. (1961), Z zagadnień socjologii wywiadu, „Studia Socjologiczne”, nr 2, 69-76.

Gostkowski Z. (1989), Wstęp, w: Analizy i próby technik badawczych w socjologii. Społeczne obrazy i stereotypy chłopa, urzędnika i robotnika. Studia eksploracyjne, t. VII. Gostkowski Z. (red.), Wrocław-Warszawa-Kraków-Gdańsk-Łódź: Ossolineum.

Gostkowski Z. (2006), Od Redakcji, w: Analizy i próby technik badawczych w socjologii, t. XI, Łódź: ŁTN.

Gostkowski Z., Lutyński J. (1968), Od Redakcji, w: Analizy i próby technik badawczych $w$ socjologii, t. II. Gostkowski Z., Lutyński J. (red.), Wrocław-WarszawaKraków: Ossolineum.

Grol-Prokopczyk H., McEniry M., Verdes E. (2011), Categorical Borders Across Borders: Can Anchoring Vignettes Identify Cross-National Differences in HealthRating Style?, Paper presented at the Population Association of America annual conference in Washington, D.C., 2 April, http://paa2011.princeton.edu/ papers/110879 (dostęp 2013).

Groves R.M. (1989), Survey errors and survey costs, New York: John Wiley \& Sons.

Grzeszkiewicz-Radulska K. (2009), Respondenci niedostępni w badaniach sondażowych, Analizy i próby technik badawczych w socjologii, t. XII. Kubiak A. (red.), Łódź: Wydawnictwo UŁ.

Grzeszkiewicz-Radulska K. (2016), Winiety zakotwiczajace jako technika obiektywizacji samoocen respondentów, niepublikowana praca dyplomowa.

Grzeszkiewicz-Radulska K., Krzewińska A. (2015), O tym, jak napisać biografię naukową (łódzka szkoła metodologiczna), „Przegląd Socjologiczny”, t. 44/4, 27-49.

Hopkins D., King G. (2010), Improving anchoring vignettes. Designing surveys to correct interpersonal incomparability, "Public Opinion Quarterly", Vol. 74, 1-22, http://gking. harvard.edu/vign/eg (dostęp 2015).

Hoorens V. (2015), Self-favoring biases, self-presentation and self-other asymmetry in social comparison, preprint artykułu, który ukazał się w “Journal of Personality”, http://researchgate.net (dostęp 2015). 
Jasińska-Kania A., Sikorska M., Kacprowicz G., Konieczna-Sałamatin J., Marody M., Henne K., Skarżyńska K., Grzymała-Kazłowska A., Mandes S., Bartkowski J., Szostek M., Wójcik A., Cisłak A. (red.) (2012), Dynamika postaw wobec pracy, w: Wartości i zmiany. Przemiany postaw Polaków w jednoczącej się Europie. Jasińska-Kania A. (red.), Warszawa: Wydawnictwo Naukowe Scholar.

Kapteyn A., Smith J.P., Soest van A., Vonkova H. (2011), Anchoring vignettes and response consistency, RAND Working Papers WR-840, https://papers.ssrn.com/ sol3/papers.cfm?ab-stract_id=1799563 (dostęp 2014).

King G., Murray C.J.L., Salomon J.A., Tandon A. (2004), Enhancing the validity and cross-cultural comparability of measurement in survey research, "American Political Science Review", Vol. 98, 191-207

King G., Wand J. (2006), Comparing incomparable survey responses: evaluating and selecting anchoring vignettes, "Political Analysis", preprint ze strony http:// gking. harvard.edu/files/c.pdf (dostęp 2011).

Koniarek J. (1975), Weryfikacja zewnętrzna informacji uzyskanych w wywiadzie kwestionariuszowym, w: Analizy i próby technik badawczych w socjologii. Studia pilotażowe i analizy weryfikacyjne, t. V. Gostkowski Z., Lutyński J. (red.), Wrocław-Warszawa-Kraków-Gdańsk: Ossolineum.

Kopczewska K., Kopczewski T., Wójcik P. (2009), Metody ilościowe w R. Aplikacje ekonomiczne i finansowe, Warszawa: CeDeWu.

Korzeniowski K. (1997), O psychospołecznych uwarunkowaniach zachowań wyborczych Polaków w latach dziewięćdziesiątych, w: Prognozy i wybory, Polska demokracja '95. Kolarska-Bobińska L., Markowski R. (red.), Warszawa: Wydawnictwo Sejmowe.

Kristensen N., Johansson E. (2008), New evidence on cross-country differences in job satisfaction using anchoring vignettes, "Labour Economics", Vol. 15, https:// pure.au.dk/ws/files/784/06-1_nik.pdf (dostęp 2012).

Krosnick J. (1991), Response strategies for coping with the cognitive demands of attitude measures in surveys, "Applied Cognitive Psychology", Vol. 5, 213-236.

Krosnick J. (1999), Survey research, “Annual Review of Psychology”, Vol. 50, 537-567.

Krzewińska A. (2006), O socjologicznym wywiadzie kwestionariuszowym: psychologia poznawcza Norberta Schwarza i jej badawcze zastosowanie w warunkach polskich, Analizy i próby technik badawczych w socjologii, t. XI. Gostkowski Z., Kubiak A. (red.), Łódź: ŁTN.

Krzewińska A. (2015), Łódzka szkoła metodologiczna w narracji „świadków”, w: Przestrzenie i ludzie. Konteksty antropologiczne. Karpińska G.E., Krupa-Ławrynowicz A. (red.), Łódź: Wydawnictwo Księży Młyn.

Krzewińska A., Grzeszkiewicz-Radulska K. (2013), Klasyfikacja sondażowych technik otrzymywania materiałów, „Przegląd Socjologiczny”, t. 62/1, 9-31.

Kubiak A. (2008), Profesor Jan Lutyński. Sylwetki łódzkich uczonych, z. 86, Łódź: ŁTN. Kubiak A., Przybyłowska I. (1999), Metodologia pragmatyczna Jana Lutyńskiego - propozycje klasyfikacji pytań kwestionariuszowych, „Przegląd Socjologiczny”, t. 48/1, 101-112. 
Lutyńska K. (1975), Weryfikacja danych uzyskanych z odpowiedzi respondentów na pytania o wysokość zarobków, w: Analizy i próby technik badawczych w socjologii. Studia pilotażowe i analizy weryfikacyjne, t. V. Gostkowski Z., Lutyński J. (red.), Wrocław-Warszawa-Kraków-Gdańsk: Ossolineum.

Lutyńska K. (1992), Metodologia badań socjologicznych w Łodzi. (Działalność Zakładu Metodologii Badań Socjologicznych IFiS PAN w Łodzi w latach 19631991), „Przegląd Socjologiczny”, t. 41, 197-209.

Lutyńska K., Szeszenia N. (1972), Wstępne wyniki zewnętrznej weryfikacji odpowiedzi respondentów w wywiadzie na temat zachowań zdrowotnych, w: Analizy $i$ próby technik badawczych $w$ socjologii. Wywiad kwestionariuszowy $w$ świetle badań metodologicznych, t. IV. Gostkowski Z., Lutyński J. (red.), WrocławWarszawa-Kraków-Gdańsk: Ossolineum.

Lutyński J. (1975), Analizy weryfikacyjne w badaniach z zastosowaniem wywiadu kwestionariuszowego, ich rodzaje i możliwości, w: Analizy i próby technik badawczych w socjologii. Studia pilotażowe i analizy weryfikacyjne, t. V. Gostkowski Z., Lutyński J. (red.), Wrocław-Warszawa-Kraków-Gdańsk: Ossolineum.

Lutyński J. (1978), Pytanie jako narzędzie w surveyowych badaniach socjologicznych, „Studia Socjologiczne”, nr 2, 93-119.

Lutyński J. (1990), Studia metodologiczne prowadzone w łódzkim ośrodku socjologicznym. Ich ogólna charakterystyka i ocena, „Acta Universitatis Lodziensis. Folia Sociologica" 20, 5-13.

Lutyński J. (1993), Orientacje metodologiczne w łódzkim ośrodku socjologicznym, „Przegląd Socjologiczny”, t. 40/1, 11-20.

Lutyński J. (1994), Metody badań społecznych. Wybrane zagadnienia, Łódź: ŁTN.

Martin E. (2006), Vignettes and respondent debriefing for questionnaire design and evaluation, "Research Report Series, Survey Methodology", Vol. 8, https://www. census.gov/srd/papers/pdf/rsm2006-08.pdf (dostęp 2016).

Marody M. (2012), Dynamika postaw wobec pracy, w: Wartości i zmiany. Przemiany postaw Polaków w jednoczącej się Europie. Jasińska-Kania A. (red.), Warszawa: Wydawnictwo Naukowe Scholar.

Miszalska A. (1996), Reakcje społeczne na przemiany ustrojowe, Łódź: Wydawnictwo UŁ.

Mokrzycki E. (1971), Podstawowe założenia „socjologii humanistycznej”, w: Metodologiczne problemy teorii socjologicznej. Nowak S. (red.), Warszawa: PWN.

Mokrzycki E. (1980), Filozofia nauk a socjologia: od doktryny metodologicznej do praktyki badawczej, Warszawa: PWN.

Mokrzycki E. (1990), Socjologia w filozoficznym kontekście, Warszawa: IFiS PAN.

Muszyński Z. (2014), Siedem cech głównych, „Forum Akademickie”, nr 3, https:// forumakademickie.pl/fa/2014/03/siedem-cech-glownych/\# (dostęp 2015).

Ossowski S. (2001), O osobliwościach nauk społecznych, Warszawa: Wydawnictwo Naukowe PWN.

Paulhus D., Reid D.B. (1991), Enhancement and denial in socially desirable responding, "Journal of Personality and Social Psychology", Vol. 60, No. 2, 307-317. 
Pełka-Sługocka M. (1970), Przeprowadzenie wywiadów z więźniami w zakładach karnych, w: Analizy i próby technik badawczych w socjologii, t. III. Gostkowski Z., Lutyński J. (red.), Wrocław-Warszawa-Kraków: Ossolineum.

Przybyłowska I. (1975), Wywiad o wywiadzie jako metoda otrzymywania informacji o reakcji wewnętrznej respondenta na pytanie kwestionariusza, w: Analizy $i$ próby technik badawczych $w$ socjologii. Studia pilotażowe i analizy weryfikacyjne, t. V. Gostkowski Z., Lutyński J. (red.), Wrocław-Warszawa-KrakówGdańsk: Ossolineum.

Przybyłowska I. (1978), Wywiad swobodny ze standaryzowana lista poszukiwanych informacji i możliwości jego zastosowania w badaniach socjologicznych, „Przegląd Socjologiczny", t. 30, 53-69.

Przybysz D. (2004), Dlaczego Polacy nie głosują? Analiza przyczyn bierności wyborczej, w: Niepokoje polskie. Domański H., Ostrowska A., Rychard A. (red.), Warszawa: IFiS PAN.

Salomon J.A., Tandon A., Murray C.J.L. (2004), Comparability of self-rated health: cross sectional multi-country survey using anchoring vignettes, "British Medical Journal", Vol. 328, 251-268

Schwarz N., Hippler H.-J., Noelle-Neuman E., Münkel T. (1989), Response order effects in long lists: primacy, recency and asymmetrics contrast effects, ZUMAArbeitsbericht Nr. 89/18, file://C:/Users/user/Downloads/ssoar 1989-schwarz et_al-response_order_effects_in_long.pdf (dostęp 2013).

Sen A. (2002), Health: perception versus observation, "British Medical Journal", Vol. 324, 860-861.

Skarżyńska K., Chmielewski K. (1994), Zostać w domu czy pójść na wybory: różne uwarunkowania decyzji wyborczych, „Kultura i Społeczeństwo”, t. 38, nr 3, 39-54.

Soest van A., Delaney L., Harmon C., Kapteyn A., Smith J.P. (2011), Validating the use of anchoring vignettes for the correction of response scale differences in subjective questions, "Journal of the Royal Statistical Society - Series A", Vol. 174, No. 3, 575-595.

Stefanowska M. (1986), Odbiorcy kultury: deklaracje i rzeczywistość: (studium metodologiczne o weryfikacji danych), Warszawa: PWN.

Sułek A. (2001), „Ilu jest w Polsce Żydów?”. Eksperymentalne studium wpływu skali na odpowiedzi ankietowe, w: Sułek A., Sondaż polski, Warszawa: IFiS PAN.

Sułek A. (2012), Social desirability po polsku, w: Metoda i znaczenie. Problematyka rozumienia w badaniach sondażowych. Grabowska M. (red.), Warszawa: CBOS.

Szacki J. (1975), O szkołach naukowych. (Zarys problematyki), „Studia Socjologiczne", nr 4 (59), 5-27.

Szczepański J. (1966), Przedmowa, w: Analizy i próby technik badawczych $w$ socjologii, t. I. Gostkowski Z. (red.), Wrocław-Warszawa-Kraków: Ossolineum.

Sztabiński F. (2011), Ocena jakości danych w badaniach surveyowych, Warszawa: IFiS PAN. 
Tuchańska B. (1975), Analiza modelu wewnętrznej reakcji respondenta na pytanie $w$ wywiadzie kwestionariuszowym, w: Analizy i próby technik badawczych $w$ socjologii. Studia pilotażowe i analizy weryfikacyjne, t. V. Gostkowski Z., Lutyński J. (red.), Wrocław-Warszawa-Kraków-Gdańsk: Ossolineum.

Wand J., King G., Lau O. (2011), Anchors: Software for anchoring vignette data, "Journal of Statistical Software", Vol. 42, http://www.jstatsoft.org/v42/i03/paper (dostęp 2012).

Wejland A.P. (2004), Jak żegnać lokalne paradygmaty. O metodologii wywiadu i naukowych wspólnotach dyskursu, „Kultura i Społeczeństwo”, t. 48, nr 1, 207-220.

Wilgenburg van K. (2010), The validity of anchoring vignettes. Testing response consistency with an experiment, Netspar - Network for studies on pensions, aging and retirement, Erasmus University, Rotterdam, Institute of Health Policy and Management, http://arno.uvt.nl/show.cgi?fid=113625 (dostęp 2013).

Woleński J. (2014), Kilka uwag (naukoznawczych) o Szkole Lwowsko-Warszawskiej, „Nauka”, nr 1, 33-42.

Wywiad z prof. Krystyna Janicka, http://polpan.org/wp-content/uploads/2014/04/ Wywiad_prof_Krystyna_Janicka.pdf (dostęp 2017).

$Z$ metodologii i metodyki socjologicznych badań terenowych, t. 1 (1971). Gostkowski Z. (red.), Warszawa: Wydawnictwo IFiS PAN.

$Z$ metodologii i metodyki socjologicznych badań terenowych, t. 2 (1973). Gostkowski Z. (red.), Warszawa: Wydawnictwo IFiS PAN.

$Z$ metodologii i metodyki socjologicznych badań terenowych, t. 3 (1974). Gostkowski Z. (red.), Warszawa: Wydawnictwo IFiS PAN.

$Z$ metodologii i metodyki socjologicznych badań terenowych, t. 4 (1976). Gostkowski Z. (red.), Warszawa: Wydawnictwo IFiS PAN.

$Z$ metodologii i metodyki socjologicznych badań terenowych, t. 5 (1978). Gostkowski Z. (red.), Warszawa: Wydawnictwo IFiS PAN.

$Z$ metodologii i metodyki socjologicznych badań terenowych, t. 6 (1981a). Gostkowski Z. (red.), Warszawa: Wydawnictwo IFiS PAN.

$Z$ metodologii i metodyki socjologicznych badań terenowych, t. 7 (1981b). Gostkowski Z. (red.), Warszawa: Wydawnictwo IFiS PAN.

$Z$ metodologii $i$ metodyki socjologicznych badań terenowych, t. 8 (1985). Lutyńska K. (red.), Warszawa: Wydawnictwo IFiS PAN.

$Z$ metodologii i metodyki socjologicznych badań terenowych, t. 9 (1989). Gostkowski Z. (red.), Warszawa: Wydawnictwo IFiS PAN. 


\section{Załączniki}

\section{Załącznik 1. Narzędzie do badania sytuacji materialnej}

M1. Jak ocenia P. obecną sytuację materialną w swoim gospodarstwie domowym? [ANKIETER: wręcz kartę] Czy jest ona:

1) Bardzo dobra

2) Dobra

3) Raczej dobra

4) Raczej zła

5) Zła

6) Bardzo zła

7) Trudno powiedzieć

M2. Przedstawię teraz P. sytuację materialną kilku rodzin. [ANKIETER: $R$. posługuje się tą sama karta]

a) Rodzinie Piotrowskich bez problemu wystarcza na podstawowe wydatki. Mogą sobie także pozwolić na kupno różnych markowych produktów. W każdym miesiącu odkładają na konto około 2 tys. złotych. Jak P. ocenia sytuację materialną tej rodziny? Czy jest ona:

1) Bardzo dobra

2) Dobra

3) Raczej dobra

4) Raczej zła

5) Zła

6) Bardzo zła

7) Trudno powiedzieć

b) W rodzinie Kwiatkowskich nie ma problemów z opłacaniem czynszu i zakupami żywności, ale muszą bardzo oszczędzać, aby kupić nowe ubrania, czy niezbędny sprzęt do domu. Jak P. ocenia sytuację materialną tej rodziny? Czy jest ona:

1) Bardzo dobra

2) Dobra

3) Raczej dobra 
4) Raczej zła

5) Zła

6) Bardzo zła

7) Trudno powiedzieć

c) W rodzinie Nowaków wystarcza pieniędzy na jedzenie i opłaty, ale nie stać już ich na nowe ubrania, ani sprzęty do domu. Jak P. ocenia sytuację materialną tej rodziny? Czy jest ona:

1) Bardzo dobra

2) Dobra

3) Raczej dobra

4) Raczej zła

5) Zła

6) Bardzo zła

7) Trudno powiedzieć

d) W rodzinie Malinowskich pieniędzy wystarcza tylko na jedzenie. Od trzech miesięcy nie płacą też za czynsz i światło. Jak P. ocenia sytuację materialną tej rodziny? Czy jest ona:

1) Bardzo dobra

2) Dobra

3) Raczej dobra

4) Raczej zła

5) Zła

6) Bardzo zła

7) Trudno powiedzieć

e) W rodzinie Kowalskich ciągle brakuje pieniędzy na podstawową żywność. Od kilkunastu miesięcy zalegają również z opłatami za czynsz i światło. Jak P. ocenia sytuację materialną tej rodziny? Czy jest ona:

1) Bardzo dobra

2) Dobra

3) Raczej dobra

4) Raczej zła

5) Zła

6) Bardzo zła

7) Trudno powiedzieć 


\section{Zatącznik 2. Narzędzie do badania potrzeby doskonalenia własnych kwalifikacji zawodowych}

B14. Czy ma P. potrzebę doskonalenia własnych kwalifikacji zawodowych? [ANKIETER: wręcz kartę]

1) Zdecydowanie tak

2) Tak

3) Raczej tak

4) Raczej nie

5) Nie

6) Zdecydowanie nie

7) Trudno powiedzieć

B15. Przedstawię teraz P. krótkie historie kilku osób. Historie te pokazują różne nastawienia ludzi do problemu dokształcania się i podnoszenia kwalifikacji zawodowych [ANKIETER: $R$. postuguje się ta sama karta. Respondentom-mężczyznom odczytuj $w$ historiach koniecznie imiona męskie, a respondentom-kobietom - koniecznie imiona żeńskie]

a) Andrzej/Joanna jest zadowolony(a) z tego, że ma spokojne miejsce pracy, w którym od lat niewiele się zmienia. Jednak po powrocie do domu i wypełnieniu obowiązków domowych, Andrzej/Joanna zawsze stara się znaleźć chwilę wolnego czasu na dokształcanie się. W zależności od dnia, czyta książki, prasę branżową lub samodzielnie uczy się języka niemieckiego. Czy P. zdaniem Andrzej/Joanna ma potrzebę doskonalenia własnych kwalifika-

cji zawodowych?

1) Zdecydowanie tak

2) Tak

3) Raczej tak

4) Raczej nie

5) Nie

6) Zdecydowanie nie

7) Trudno powiedzieć

b) Michał/Małgorzata od wielu lat pracuje w tej samej firmie. Uważa, że ta praca bardzo go/ją rozwija. Wysoko ceni sobie wiedzę i umiejętności, które zdobywa poprzez wymianę doświadczeń z innymi pracownikami. Michał/ Małgorzata nie korzysta z żadnych szkoleń - jego/jej zdaniem, wszystkie potrzebne umiejętności nabywa w pracy. Czy P. zdaniem Michał/Małgorzata ma potrzebę doskonalenia własnych kwalifikacji zawodowych?

1) Zdecydowanie tak

2) Tak

3) Raczej tak

4) Raczej nie

5) Nie 
6) Zdecydowanie nie

7) Trudno powiedzieć

c) Dariusz/Anna ma pracę, na której bardzo mu/jej zależy. Kiedy pracodawca daje mu/jej możliwość odbycia jakichś szkoleń, Dariusz/Anna zwykle z tego korzysta, ponieważ wie, iż firma zwraca na to uwage przy ocenie pracowników. Odbywanie kursów to dla niego/niej wysiłek, gdyż musi poświęcić własny czas na nie zawsze wartościowe zajęcia. Czy P. zdaniem Dariusz/Anna ma potrzebę doskonalenia własnych kwalifikacji zawodowych?

1) Zdecydowanie tak

2) Tak

3) Raczej tak

4) Raczej nie

5) Nie

6) Zdecydowanie nie

7) Trudno powiedzieć

d) Jedynym celem pracy Tomasza/Doroty jest utrzymanie siebie i rodziny. Jak sam(a) mówi, po powrocie z roboty tylko marzy, żeby odpocząć. Spełni domowe obowiązki, a potem ogląda telewizję lub czyta prasę, często korzysta z komputera i dyskutuje na forach internetowych. Czy P. zdaniem Tomasz/ Dorota ma potrzebę doskonalenia własnych kwalifikacji zawodowych?

1) Zdecydowanie tak

2) Tak

3) Raczej tak

4) Raczej nie

5) $\mathrm{Nie}$

6) Zdecydowanie nie?

7) Trudno powiedzieć

e) Piotr/Katarzyna ma dobrą pracę, jednak bardzo często przegląda gazety i szuka ofert od innych pracodawców. Z proponowanych przez firmę szkoleń zawsze korzysta. Kilka kursów odbył(a) z własnej inicjatywy. Na niektóre szkolenia przeznaczył(a) własne pieniądze. Czy P. zdaniem Piotr/Katarzyna ma potrzebę doskonalenia własnych kwalifikacji zawodowych?

1) Zdecydowanie tak

2) Tak

3) Raczej tak

4) Raczej nie

5) Nie

6) Zdecydowanie nie?

7) Trudno powiedzieć 


\section{Verification analysis in social surveys. Past and present research experiences (Summary)}

The authors of the book, students of the founders and representatives of the Lodz school of methodology in sociology, reflect on verification analyses, which were the subject of theoretical and empirical researches in that school for many years. Jan Lutyński's unique conception of analyses for internal verification, which was unique in methodology of survey research, remains a particularly important reference point of those reflections. Attempts to face the legacy of the school along with its discussion and assessment, are accompanied by voices of the school's representatives referring to the then concepts, research enterprises and achievements from today's perspective. Interviewing the majority of the school's researchers enabled to include this element into the retrospective. As a result, methodological issues are intertwined with issues of interest to sociology of science.

Continuing research interests of their teachers, the authors explore possibilities of the widely understood internal verification by studying the technique of anchoring vignettes in the second part of the work. This method was developed by King et al. (2004) to address the problem of interpersonal and cross-cultural incomparability, also called differential item functioning (DIF), that may affect respondents' selfassessments. DIF occurs when respondents use the ordinal response categories in different ways because they differ in their evaluation standards. As a consequence, measuring reality only by asking about respondents' perception can be misleading. The method can be correct for DIF by supplemental vignette questions that make it possible to construct a common scale of measurement across respondents. However, this approach requires some assumptions for results to be valid. One of them, that is response consistency (RC), says that each respondent uses the response categories for the self-assessment question in the same way that he or she uses them to evaluate hypothetical scenarios in vignettes (one person applies the same type of DIF across these two types of questions). To test this assumption external data (or objective indicators) are needed to compare an object under study with some standard. 
In our study we investigated whether DIF occurs for material living conditions and needs for lifelong learning. We also aimed to check whether RC assumption holds for these two domains. Data were gathered in 2011 using quota sample $(n=1000)$ of citizens from the Skierniewice subregion, that is women aged 25-59 and men aged 25-64. The sample was selected by three criteria: gender, age and place of living.

According to our findings law-income and high-income respondents do differ in their standards for what constitutes satisficing level of material living conditions, however, DIF was not sizeable. A similar conclusion applies for the second domain under study for respondents practicing and not practicing lifelong learning, respectively. Moreover, for material living conditions we find some evidence that $\mathrm{RC}$ assumption can be violated indicating that low-income respondents use different DIF when providing self-assessment and evaluating scenarios in vignettes. The reason we suggest is that low-income respondents found the question about their living conditions threating their good self-esteem. 